
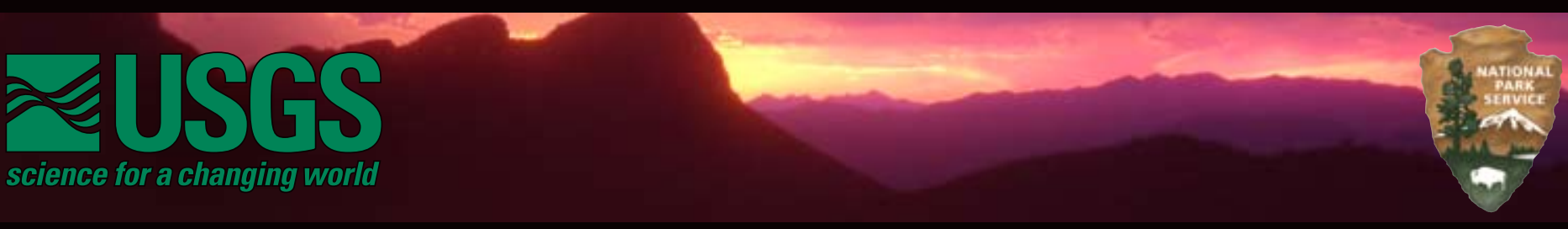

In Cooperation with the University of Arizona, School of Natural Resources

\title{
Vascular Plant and Vertebrate Inventory of Gila Cliff Dwellings National Monument
}

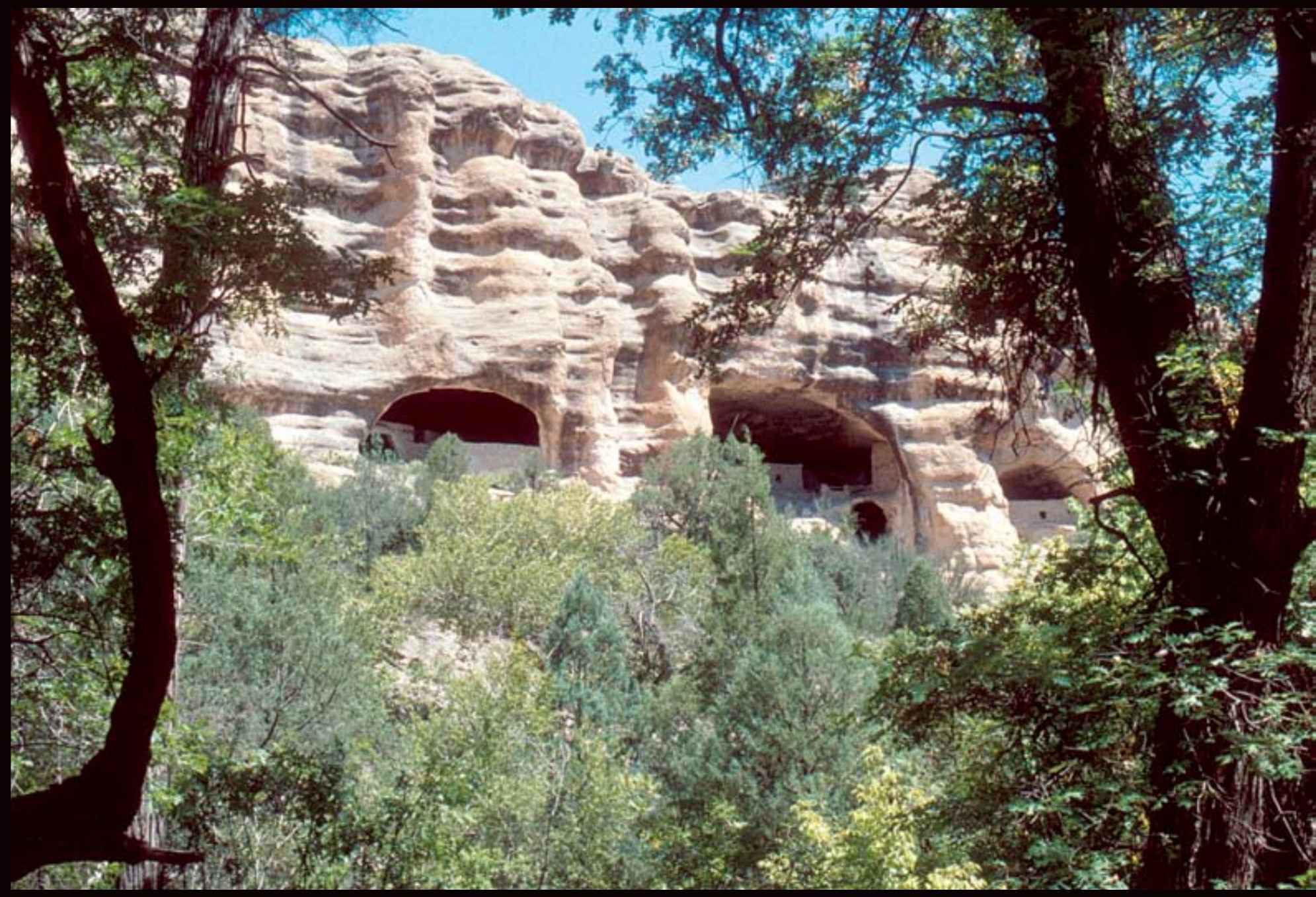

Southwest Biological Science Center

Open-File Report 2005-1187

September 2006

U.S. Department of the Interior

U.S. Geological Survey

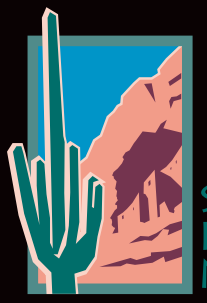





\section{Vascular Plant and Vertebrate Inventory of Gila Cliff Dwellings National Monument}

By Brian F. Powell, Eric W. Albrecht, William L. Halvorson, Cecilia A. Schmidt, Kathleen Docherty, and Pamela Anning

Open-File Report 2005-1187

September 2006

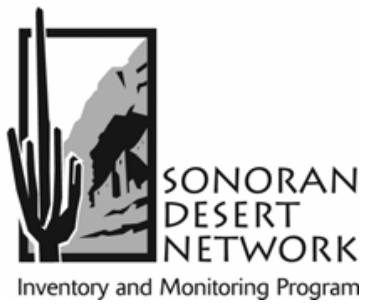

U.S. Department of the Interior

U.S. Geological Survey National Park Service
USGS Southwest Biological Science Center Sonoran Desert Research Station University of Arizona School of Natural Resources 125 Biological Sciences East Tucson, Arizona 85721 


\section{U.S. Department of the Interior \\ Dirk Kempthorne, Secretary}

\section{U.S. Geological Survey \\ Mark Myers, Director}

U.S. Geological Survey, Reston, Virginia: 2006

Note: This document contains information of a preliminary nature and was prepared primarily

for internal use in the U.S. Geological Survey. This information is NOT intended for use in open

literature prior to publication by the investigators named unless permission is obtained in writing from the investigators named and from the Station Leader.

Suggested Citation

Powell, B.F, E. W. Albrecht, W. L. Halvorson, C. A. Schmidt, K. Docherty, and P. Anning 2006. Vascular Plant and Vertebrate Inventory of Gila Cliff Dwellings National Monument. USGS Open-File Report 2005-1187. U.S. Geological Survey, Southwest Biological Science Center, Sonoran Desert Research Station, University of Arizona, Tucson, AZ.

Printed on recycled paper

Cover photo: Namesake cliff dwellings of the Gila Cliff Dwellings National Monument, New Mexico. Photograph by Brian Powell. 


\section{Authors}

Brian F. Powell

School of Natural Resources

125 Biological Sciences East, Building 43

The University of Arizona

Tucson, AZ 85721

William L. Halvorson

USGS SBSC Sonoran Desert Research Station

125 Biological Sciences East, Building 43

The University of Arizona

Tucson, AZ 85721
Kathleen Docherty and Pamela Anning National Park Service

\section{U.S. Geological Survey SBSC Sonoran Desert Research Station Personnel}

Charles van Riper III, Station Leader

Steve P. Gloss, Ecologist

William L. Halvorson, Research Ecologist

Cecil R. Schwalbe, Ecologist

Michael R. Kunzmann, Ecologist (Emeritus)

Kathryn Thomas, Ecologist

Pamela Nagler, Physical Scientist

Phil Rosen, Ecologist

\section{Program and Expertise Areas of USGS and UA Personnel}

Administration \& Outreach

Kate Leonard

Jennifer Meador

Wendy Parrish

Emily Sherbrooke

Charles van Riper III

Avian Ecology

Claire Crow

Glenn Johnson

Chris O’Brien

Brian Powell

Charles van Riper III

Data Management

Brent Sigafus

Ecology of Amphibians \& Reptiles

Kevin Baker

Cristina Jones

Dave Prival

Phil Rosen

Cecil Schwalbe

Brent Sigafus
Fire Management

Dennis Suhre

Cori Dolan

James Feldmann

Bill Halvorson

Invasive Species Research

Patricia Guertin

Jim Malusa

Phil Rosen

Cecil Schwalbe

Brent Sigafus

Dennis Suhre

Kathryn Thomas

Inventory \& Monitoring

Patricia Guertin

Bill Halvorson

Pamela Nagler

Brian Powell

Cecilia Schmidt

Vegetation Mapping \& Ecology

Patricia Guertin

Bill Halvorson

Jim Malusa

Kathryn Thomas

USGS Southwest Biological Science Center http://sbsc.wr.usgs.gov

USGS Southwest Biological Science Center, Sonoran Desert Research Station http://sbsc.wr.usgs.gov/sdrs 


\section{Table of Contents}

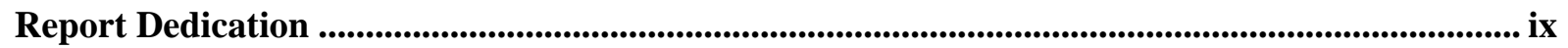

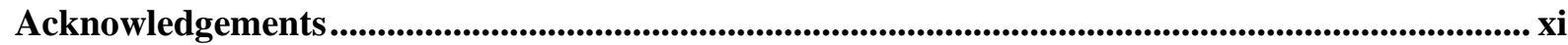

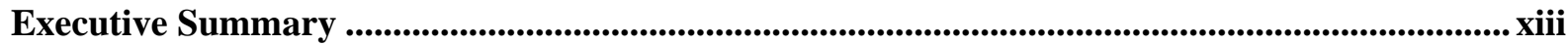

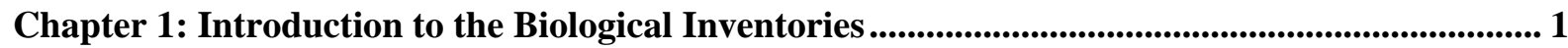

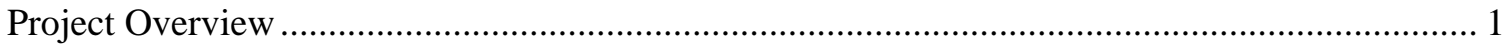

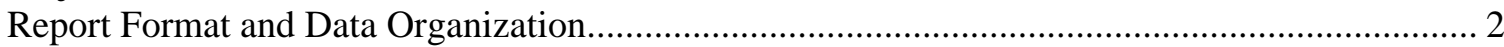

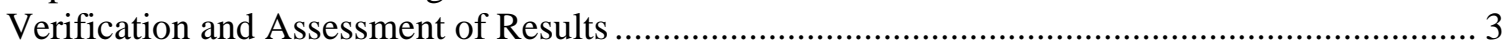

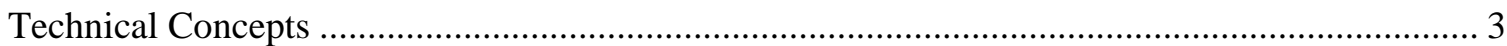

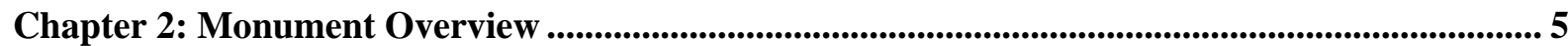

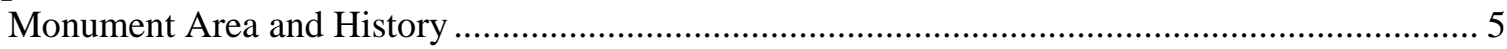

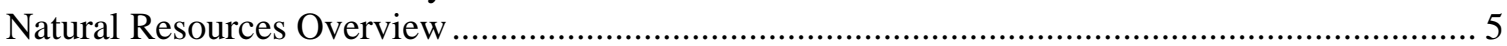

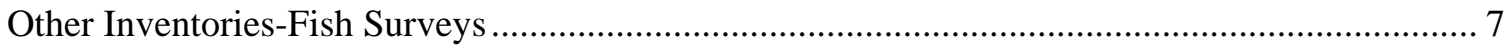

Natural Resource Management Issues.................................................................................. 9

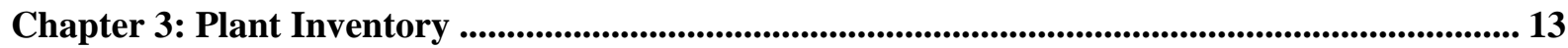

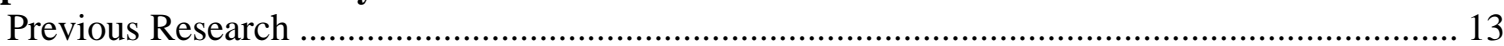

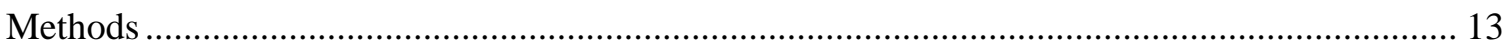

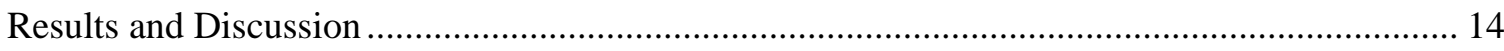

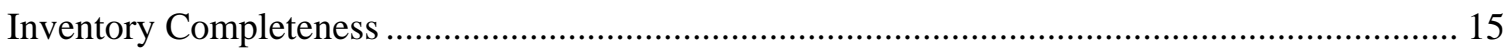

Chapter 4: Amphibian and Reptile Inventory............................................................................. 17

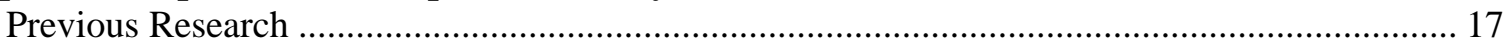

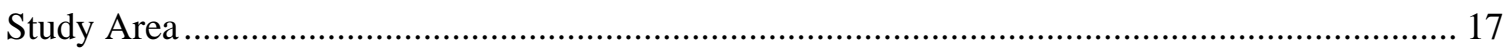

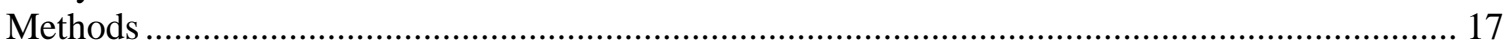

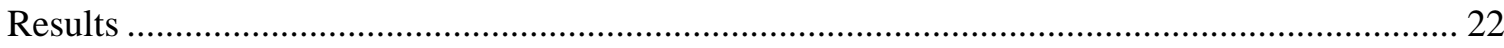

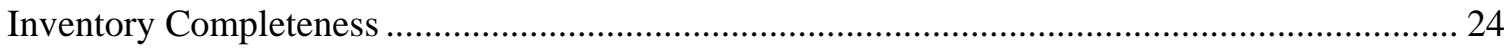

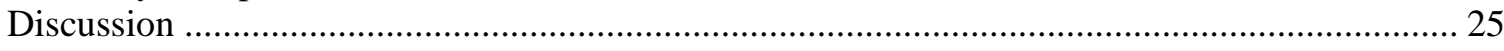

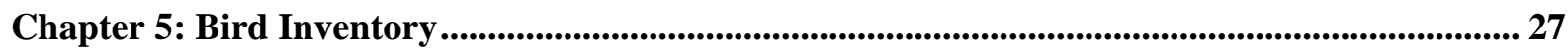

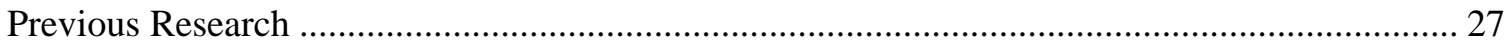

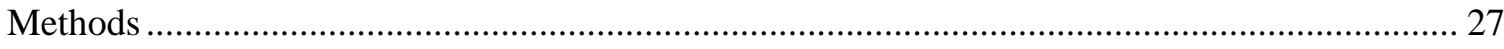

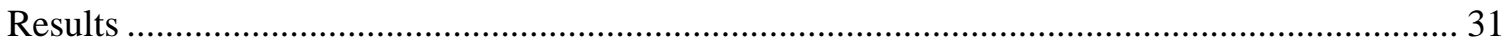

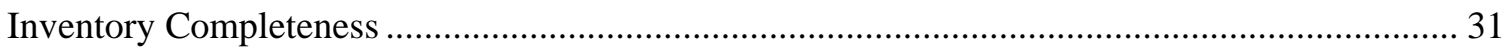

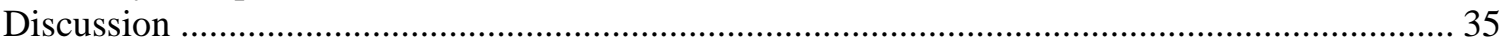

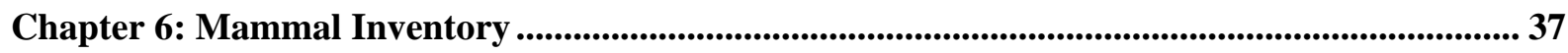

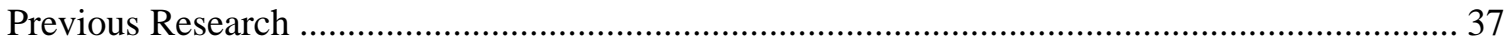

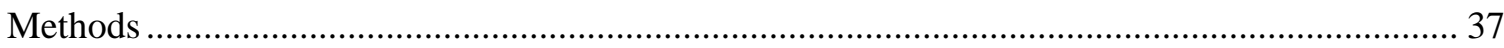

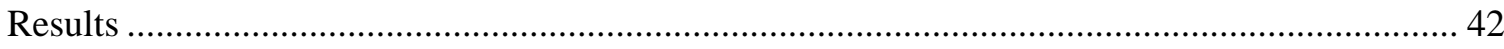

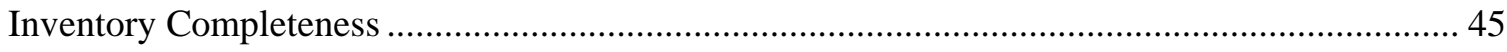

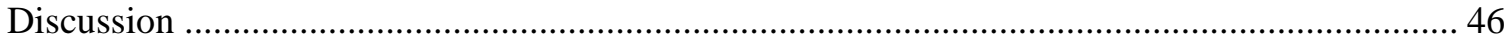

Chapter 7: Management Implications........................................................................................................... 49

Chapter 8: Additional Inventories .............................................................................................................. 51

Chapter 9: Literature Cited ..................................................................................................................... 53 


\section{List of Tables}

Table 1. Summary results of vascular plant and vertebrate inventories at Gila Cliff Dwellings NM, 2000-2003. xiii

Table 2.1. Average monthly climate data for Gila Hot Springs, New Mexico, 1915-2004.

Table 3.1. Field survey effort for general botanizing surveys, Gila Cliff Dwellings NM, 20012003.

Table 4.1. Herpetofaunal survey effort by method, Gila Cliff Dwellings NM, 2001 and 2002.

Table 4.2. Number of observations $(\mathrm{N})$ and relative abundance (mean $+\mathrm{SE}$ ) of herpetofauna detected during area-constrained transects and time-constrained searches, Gila Cliff Dwellings NM, 2001 and 2002.

Table 4.3. Number of observations $(\mathrm{N})$ and relative abundance (mean $+\mathrm{SE}$ ) of herpetofauna detected during time-and-area constrained searches, by community type, Gila Cliff Dwellings NM, 2001 and 2002.

Table 4.4. Number of observations $(\mathrm{N})$ and relative abundance (mean $+\mathrm{SE}$ ) of herpetofauna detected during extensive surveys (diurnal and nocturnal surveys), by community type, and total number of incidental observations, Gila Cliff Dwellings NM, 2001 and 2002 .

Table 4.5. Number of observations $(\mathrm{N})$ and relative abundance (mean $+\mathrm{SE}$ ) of herpetofauna detected during road transect surveys, Gila Cliff Dwellings NM, 2001 and 2002.

Table 5.1. Mean density (ha) of the most common tree species at each station along the two VCP transects, Gila Cliff Dwellings NM, 2002.

Table 5.2. Number of observations (sum) and relative abundance (mean \pm SE) of birds observed within $75 \mathrm{~m}$ of stations along the Riparian transect, Gila Cliff Dwellings NM, 2001 and 2002.

Table 5.3. Number of observations (sum) and relative abundance (mean \pm SE) of birds observed within $75 \mathrm{~m}$ of stations along the Canyon transect, Gila Cliff Dwellings NM, 2001 and 2002.

Table 5.4. Number of breeding-behavior observations for birds, Gila Cliff Dwellings NM, 2001 and 2002. .34

Table 6.1. Summary of bat survey effort, Gila Cliff Dwellings NM, 2001 and 2002........................ 40

Table 6.2. Small-mammal trapping effort, Gila Cliff Dwellings NM, 2001 and 2002 ..................... 40

Table 6.3. Summary of Trailmaster camera effort, Gila Cliff Dwellings NM, 2001 and 2002.......... 43

Table 6.4. Number of bats captured ( $n$ ) and percent netting success (PNS) at three mist-netting sites at Gila Cliff Dwellings NM, 2001 and 2002.

Table 6.5. Total number of small mammals trapped (n) and percent relative abundance (RA), excluding recaptures, by trapping group, Gila Cliff Dwellings NM, 2001 and 2002. ...... 44

Table 6.6. Results from Trailmaster cameras, Gila Cliff Dwellings NM, 2001 and 2002. 


\section{List of Figures}

Figure 2.1. Location of Gila Cliff Dwellings NM in western New Mexico.......................................... 6

Figure 2.2. Study area and monument boundaries, Gila Cliff Dwellings NM. .................................. 7

Figure 2.3. Comparison of monthly weather data during the time of the inventory (2000-2002) compared to the mean (1915-2004; thick solid line in both figures), Gila Hot Springs, New Mexico.

Figure 2.4. Photographs of Gila Cliff Dwellings, NM ..................................................................... 10

Figure 3.1. Species accumulation curve for the number of new plant species collected by month and year of the most intensive collections, Gila Cliff Dwellings NM, May-

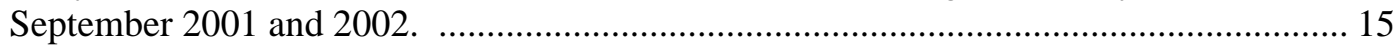

Figure 4.1. Survey plot locations for herpetofauna, Gila Cliff Dwellings NM, 2001 and 2002......... 17

Figure 4.2. Species accumulation curves for intensive and extensive amphibian and reptile surveys, Gila Cliff Dwellings NM, 2001 and 2002....................................................... 24

Figure 5.1. Location of bird survey stations, Gila Cliff Dwellings NM........................................... 28

Figure 5.2. Species accumulation curves for detections from all bird surveys combined, Gila Cliff Dwellings NM, 2001 and 2002.

Figure 6.1. Locations of bat-netting sites and Trailmaster (infra-red triggered) cameras, Gila Cliff Dwellings NM, 2001 and 2002. 38

Figure 6.2. Locations of small-mammal trapping plots, Gila Cliff Dwellings NM, 2001 and 2002. 39

Figure 6.3. Diagram of Trailmaster camera set-up. 42

Figure 6.4. Species accumulation curve for mammal surveys, Gila Cliff Dwellings NM, 2001 and 2002. 


\section{List of Appendices}

Appendix A. Plant species that were observed or documented at Gila Cliff Dwellings NM by University of Arizona Inventory personnel (UA) 2001-2003 or by specimens located at the University of Texas-El Paso (UTEP) herbarium.

Appendix B. Amphibian and reptile species observed, documented with photo voucher, or documented with specimen voucher by University of Arizona Inventory

personnel, Gila Cliff Dwellings NM, 2001 and 2002. 67

Appendix C. Number of observations of bird species by survey type by University of Arizona Inventory personnel, Gila Cliff Dwellings NM, 2001 and 2002. 68

Appendix D. Number of observations of mammal species by survey type by University of Arizona Inventory personnel, Gila Cliff Dwellings NM, 2001 and 2002.

Appendix E. Amphibian and reptile species that were not recorded by University of Arizona Inventory personnel but that may occur at Gila Cliff Dwellings NM 71

Appendix F. Bird species that were not observed by University of Arizona Inventory personnel but that may occur at Gila Cliff Dwellings NM. 72

Appendix G. Mammal species that were not recorded by University of Arizona Inventory personnel but that are known to or may occur at Gila Cliff Dwellings NM.

Appendix H. Vertebrate specimen and photograph vouchers collected by University of Arizona Inventory personnel, Gila Cliff Dwellings NM, 2001 and 2002. 75

Appendix I. Number of amphibian and reptile specimen vouchers located at the Museum of Southwestern Biology, University of New Mexico.

Appendix J. Report by Philip C. Rosen on the expected amphibians and reptiles of Gila Cliff Dwellings National Monument, NM. 78

Appendix K. Number of birds observed during VCP and incidental surveys, Gila Cliff Dwellings NM, April-July 2001 and 2002.

Appendix L. Additional bat-netting data, Gila Cliff Dwellings NM, 2001 and 2002.

Appendix M. Number of individual small mammals trapped $(n)$ and relative abundance (RA) adjusted for trap nights at each group, site, and visit number, Gila Cliff Dwellings NM, 2001 and 2002. 


\section{Report Dedication}

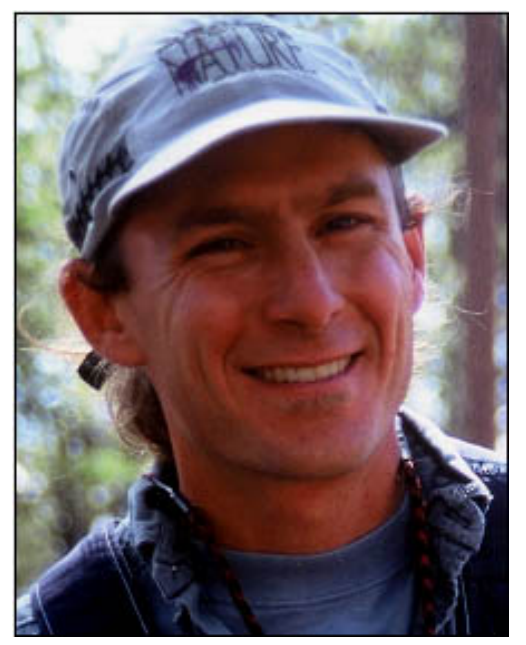

\section{Eric Wells Albrecht 1970-2004}

This report, as others in this series, is dedicated to Eric's life and work; he was an extraordinary ecologist, community member, father, and partner. Eric was co-coordinator of the University of Arizona (UA) biological inventory and monitoring program from 2002 until his sudden and unexpected death on September 20, 2004. Eric was near completion of his MS degree in Wildlife Conservation from the UA, which was awarded posthumously in November 2004. In his last year, Eric spearheaded projects to investigate the efficiency of current monitoring programs; he was passionate about using the best available information to guide vertebrate monitoring efforts in the region. He is survived by his partner, Kathy Moore, and their two young children, Elizabeth and Zachary. We hope that the lives of his children will be enriched by Eric's hard work on behalf of the national parks in the Sonoran Desert Network. 


\section{Acknowledgements}

Thanks to Park Superintendents Steve Riley and Doug Ballou and the staff and volunteers at Gila Cliff Dwellings NM. This project resulted from the collaboration of many people at the University of Arizona (UA), National Park Service (NPS), U.S. Geological Survey (USGS), and United States Forest Service (USFS), and was facilitated by the Desert Southwest and Colorado Plateau Cooperative Ecosystem Studies Units (CESUs). The NPS Natural Resource Challenge program funded the project and the Desert Southwest CESU provided financial support for a 'Naturalist in Residence' project at the monument, which significantly advanced the projects's objectives. Larry Norris, NPS Research Coordinator, spent considerable time and effort providing clear and timely administrative assistance on all aspects of the inventory project. The Southern Arizona Office of the NPS facilitated development of the original study plan that led directly to initiation of this project. Andy Hubbard, Network Coordinator of the Sonoran Desert Network (SDN) Inventory and Monitoring (I\&M) program, has been a strong and convincing advocate for continuing and expanding the role of the USGS/UA Inventory project. Kathy Davis, Superintendent at Tuzigoot and Montezuma Castle national monuments, played an instrumental role in this project, providing important early initiative. Matt Goode, Don Swann, and Dale Turner provided much of the early planning for this project; we are indebted to their vision and work. Eric Albrecht, to whom this report is dedicated, was an outstanding spokesperson and leader of the project; he was an invaluable member of the team and his contributions are sorely missed. This report was the last project that Eric worked on.

We thank a core group of dedicated field biologists who collected a wealth of data at Gila Cliff Dwellings NM: Greta Anderson, Theresa DeKoker, Meg Quinn, and Patty West (plants); Dan Bell, Kevin Bonine, James Borgmeyer, Dave Prival, and Mike Wall (amphibians and reptiles); Gavin Beiber, Chris Kirkpatrick, and Gabe Martinez (birds); Neil Perry, Jason Schmidt, and Ronnie Sidner (mammals). A special thanks to Emily Bennett for serving as the UA inventory representative during her two summers of work as a 'Naturalist in Residence' at the monument. Emily provided muchneeded technical support to the monument staff and was a valued and trusted member of that team, all the while advancing the mission of the inventory project. Emily also coordinated collection of data from monument staff and volunteers: Anita Deming, Scott Doty, Trish London, Jim Worthington, and Dave Young.

We are appreciative of the following people whose office tasks made the field effort possible: Debbie Angell, Jennifer Brodsky, Brian Cornelius, Carianne Funicelli, Taylor Edwards, Colleen McClain, Heather McClaren, Lindsay Norpel, Jill Rubio, Brent Sigafus, Taffy Sterpka, Patina Thompson, Jenny Treiber, and Alesha Williams. Additional administrative support was provided by Valery Catt at the USGS Sonoran Desert Research Station and Terri Rice, Andy Honaman, Jenny Ferry, and especially Cecily Westphal of the School of Natural Resources at the UA. Special thanks to Lisa Carder for her years of hard work on all aspects of the project.

Technical support was provided by: Dan Austin, Michael Chamberland, Phil Jenkins, and Charlotte and John Reeder of the UA Herbarium; Arthur Harris and George Worthington of the Centennial Museum at the University of Texas at El Paso; George Bradley of the UA herpetology collection; Tom Huels of the UA ornithology collection; and Yar Petryszyn and Melanie Bucci of the UA mammal collection. Thanks to Sharon Megdal and Peter Wierenga of the UA Water Resources Research Center and all their staff, especially Terry Sprouse and colleagues for use of background information on the monument contained in this report. We received helpful reviews of an early draft of this report from: Debbie Angell, Emily Bennett, Dennis Finn, Brooke Gebow, Bruce Hayward, Larry Laing, Larry Norris, Therresa Mau-Crimmons, Jerry Monzingo, Don Swann, and Charles van Riper. Charlie Painter and Phil Rosen reviewed the amphibian and reptile chapter. All mistakes and omissions are the responsibility of the authors. 


\section{Executive Summary}

This report summarizes the results of the first comprehensive biological inventory of Gila Cliff Dwellings National Monument (NM) in western New Mexico. This project was part of a larger effort to inventory plants and vertebrates in eight National Park Service units in Arizona and New Mexico. Our surveys address many of the objectives that were set forth in the monument's natural resource management plan almost 20 years ago, but until this effort, those goals were never accomplished.

From 2001 to 2003 we surveyed for vascular plants and vertebrates (amphibians, reptiles, birds, and mammals) at Gila Cliff Dwellings NM to document presence of species within the boundaries of the monument. For all taxonomic groups that we studied, we collected "incidental" sightings on U.S. Forest Service lands adjacent to the monument, and in a few cases we did formal surveys on those lands. Because we used repeatable study designs and standardized field techniques, these inventories can serve as the first step in a biological monitoring program for Gila Cliff Dwellings NM and surrounding lands.

We recorded 552 species at Gila Cliff Dwellings NM and the surrounding lands (Table 1). We found no non-native species of reptiles, birds, or mammals, one non-native amphibian (American bullfrog), and 33 non-native plants. Particularly on lands adjacent to the monument we found that the American bullfrog was very abundant, which is a cause for significant management concern. Species of non-native plants that are of management concern include red brome, bufflegrass, and cheatgrass.

For a park unit of its size and geographic location, we found the plant and vertebrate communities to be fairly diverse; for each taxonomic group we found representative species from a wide range of taxonomic orders and/or families. The monument's geographic location, with influences from the Rocky Mountain, Chihuahuan Desert, and Madrean ecological provinces, plays an important role in determining the species richness at the monument. Also important is the wide range of conditions at the site. The diversity of plants results from a wide variety of soil types and aspects (from the cool, moist Cliff Dweller Canyon to dry mesa slopes) and an abundance of water from the West Fork of the Gila River. In turn, the vertebrate communities respond to this diversity of vegetation, topography, and microsites. For example, for each taxonomic group we found species that were only associated with a single community type, most often the riparian areas along the West and Middle forks of the Gila River.

We found cause for significant concern with regard to loss of species in the last few decades. One species of amphibian (Chiricahua leopard frog) is certainly extirpated from the area. Three other species of amphibians (Mexican spadefoot, Woodhouse's toad, and red-spotted toad), reported as being "common" in the area

Table 1. Summary results of vascular plant and vertebrate inventories at Gila Cliff Dwellings NM, 20002003.

\begin{tabular}{|c|c|c|c|}
\hline Taxonomic group & $\begin{array}{c}\text { Number of } \\
\text { species recorded }\end{array}$ & $\begin{array}{c}\text { Number of } \\
\text { non-native species }\end{array}$ & $\begin{array}{l}\text { Number of new species } \\
\text { added to monument list }\end{array}$ \\
\hline Plants & 387 & 32 & 264 \\
\hline Amphibians and Reptiles & 21 & 1 & 15 \\
\hline Birds & 107 & 0 & 107 \\
\hline Mammals & 37 & 0 & 25 \\
\hline Totals & 552 & 33 & 411 \\
\hline
\end{tabular}

a Species that had not been observed or documented by other studies at or near the monument. 
in 1971, were not found during our surveys. In addition, we did not find three species of rodents that were found in 1965: silky pocket mouse, Ord's kangaroo rat, and southern grasshopper mouse. The monument's aquatic vertebrate component, in particular, may be at a critical juncture whereby other species, such as gartersnakes, may be poised for extirpation. Declining abundance of native fish species has been demonstrated from long-term monitoring of these communities along the Middle Fork of the Gila River.

This report includes lists of species recorded by us or species likely to be recorded with additional survey effort. It also includes management implications from our work - how the monument staff might better maintain or enhance the unique biological resources of the monument. This study is the first step in a long-term process of compiling information on the biological resources of the monument and its surrounding areas. We recommend additional inventory and monitoring studies and identify components of our effort that could be improved upon, either through the application of new techniques or by extending the temporal and/or spatial scope of our work. 


\section{Chapter 1: Introduction to the Biological Inventories}

\section{The natural resources of the small monument are notable for their beauty, but little has yet been done to document them. (Russell 1992)}

\section{Project Overview}

Inventory: A point-in-time effort to document the resources present in an area.

In the early $1990 \mathrm{~s}$, responding to criticism that it lacked basic knowledge of natural resources within parks, the National Park Service (NPS) initiated the Inventory and Monitoring Program (NPS 1992). The purpose of the program is to increase scientific research in NPS units and to detect long-term changes in biological resources. At the time of the program's inception, basic biological information, including lists of plants and animals, were absent or incomplete for many park units (Stohlgren et al. 1995).

Species inventories have both direct and indirect value for management. Species lists facilitate resource interpretation and visitor appreciation of natural resources. Knowledge of which species are present, particularly sensitive species, and where they occur is critical for making management decisions (e.g., locating new facilities). Inventories are also a cornerstone of long-term monitoring. Thorough biological inventories provide a basis for choosing parameters to monitor and can provide initial data (i.e., a baseline) for monitoring ecological populations and communities. Inventories can also test sampling designs, field methods, data collection protocols, and provide estimates of variation that are essential in prospective power analyses.

\section{Goals}

The purpose of this study was to complete basic inventories for vascular plants and vertebrates at Gila Cliff Dwellings NM. This effort was part of a larger biological inventory of eight NPS units in southern Arizona and southwestern New Mexico (Davis and Halvorson 2000, Powell et al. 2005a). The results presented in this report supersede those reported by Powell et al. (2002, 2003, and 2005b).

The goals of our biological inventory of Gila Cliff Dwellings NM were to:
1. Conduct field surveys to documenting at least $90 \%$ of all species of vascular plants and vertebrates expected to occur at the monument.

2. When appropriate, use repeatable sampling designs and survey methods that allow estimation of parameters of interest with associated estimates of precision.

3. Compile historic occurrence data from three sources: museum records (specimen vouchers), previous studies, and monument records.

4. Create resources useful to monument managers including detailed species lists, maps of study sites, and high-quality digital images for use in resource interpretation and education.

The bulk of our effort addressed the first two goals. To maximize efficiency (i.e., the number of species recorded by effort) we used field techniques designed to detect multiple species. We did not undertake single-species surveys for threatened or endangered species. Lastly, we did not survey for fish, as there is an active monitoring program for fish in both the West Fork and Middle Fork of the Gila River (Propst et al. 1998, Propst 2000).

\section{Administrative History}

The original study plan for this project was developed, and an inventory of one SDN park (Tumacácori National Historical Park) was completed, through a cooperative agreement among NPS, UA, and the USGS. This project was funded through Task Agreements UAZ-03, -05, -06, and (under Colorado Plateau CESU cooperative agreement number 1200-99-009). The National Park Service thereafter obligated additional funds through the Colorado Plateau CESU (UAZ-07) and the Desert Southwest CESU (cooperative agreement number CA1248-00-002, reference UAZ-39, UAZ-77, UAZ-87, UAZ-97, and UAZ-128) for administration and management 
of the biological inventories. The Desert Southwest CESU allocated additional project funds for a separate, but complementary effort, the Biological Inventory and Interpretive Project at Gila Cliff Dwellings NM (cooperative agreement number CA1248-00-002, UAZ-04 and UAZ-27). Information from that effort supplemented our species lists/surveys and facilitated our biological inventories.

\section{Report Format and Data Organization}

This report is intended to be useful for internal planning and outreach and education. We report only common names (listed in phylogenetic sequence for vertebrates) unless we reference a species that is not listed later in an appendix; in this case we present both common and scientific names. For each taxonomic group we include an appendix of all species that we recorded in the monument (Appendices A-D), and species that were likely present historically or that we suspect are currently present and may be recorded with additional survey effort (except for plants; Appendices E-G). Species lists are in phylogenetic sequence and include taxonomic order, family, genus, species, subspecies or variety (if applicable) and common name. Scientific and common names used throughout this document are current according to accepted authorities for each taxonomic group: Integrated Taxonomic Information System (ITIS 2004) and the PLANTS database (USDA 2004; including designation of plants as "non-native") for plants; Stebbins (2003) for amphibians and reptiles; American Ornithologist Union (AOU 1998, 2003) for birds; and Baker et al. (2003) for mammals. To maintain consistency throughout the document, we do not capitalize the first letter of common names unless they are proper names. In this document we use the International System of Units for measurements.

\section{Spatial Data}

Most spatial data are geographically referenced to facilitate mapping of study plots and locations of plants or animals. Coordinates were stored in the Universal Transverse Mercator (UTM) projection (Zone 12), using the North American Datum of 1983 (NAD 83). We recorded most UTM coordinates using hand-held Garmin EMap $^{\circledR}$ Global Positioning System (GPS) units (Garmin International Incorporated, Olathe, KS; horizontal accuracy about $10-30 \mathrm{~m}$ ) because of their convenience and relative simplicity. We obtained some plot or station locations by using more accurate Trimble Pathfinder ${ }^{\mathbb{B}}$ GPS units (Trimble Navigation Limited, Sunnyvale, CA; horizontal accuracy about $1 \mathrm{~m}$ ). For each taxonspecific chapter of this document we mapped the location of all plots or stations overlaid on Digital Orthophoto Quarter Quads (DOQQ; produced by the U.S. Geological Survey). All study-site coordinates are stored at the same locations as for data archiving (below).

\section{Species Conservation Designations}

We indicate species conservation designations by the following agencies: U.S. Fish and Wildlife Service (responsible for administering the Endangered Species Act), Bureau of Land Management, U.S. Forest Service (Region 3), New Mexico Game and Fish Department, and Partners in Flight (a partnership of federal, state and local governments, non-governmental organizations, and private industry).

\section{Databases and Data Archiving}

We entered field data into taxon-specific databases (Microsoft Access version 97) and checked all data for transcription errors. From these databases we reproduced copies of the original field datasheets using the "Report" function in Access. The output looks similar to the original datasheets but data are easier to read. The databases, printouts, and other data such as digital photographs and GIS layers will be distributed to the monument and to the University of Arizona, Special Collections (Main Library, Tucson). Original copies of all datasheets will be given to the NPS SDN I\&M program office in Tucson and may be archived at another location (most likely at the Western Archaeological Conservation Center, Tucson; Andy Hubbard, pers. comm.). This redundancy in data archiving is to ensure that these valuable data are never 
lost. Along with the archived data we will include copies of the original datasheets and a guide to filling them out. This information, in conjunction with the text of this report, should enable future researchers to repeat our work.

\section{Verification and Assessment of Results}

\section{Photographic Vouchers}

Whenever possible we documented vertebrate species with analog color photographs. Many of these photos show detail on coloration or other characteristics of visual appearance, and they may serve as educational tools for the monument staff and visitors. Photographs will be archived with other data as described above.

\section{Specimen Vouchers}

With proper documentation, specimen vouchers are the most indisputable form of evidence of species occurrence. Before taking vertebrate voucher specimens, we searched for existing vouchers from Gila Cliff Dwellings NM in the collections at the University of Arizona and the Museum of Southwestern Biology at the University of New Mexico (Albuquerque). When we collected specimen vouchers, we tried to use individuals that were killed incidentally (e.g., roadkill) whenever possible, but we occasionally euthanized animals, particularly when identification was uncertain (e.g., many small mammal species exhibit subtle variations in pelage color patterns within species and external measurements overlap among species). The University of Arizona's Institution for Animal Care and Use approved all field protocols for euthanizing animals (Protocol Control Number 03-177). Specimens were prepared according to standardized techniques and accessioned into the appropriate vertebrate collection at the University of Arizona (vertebrate vouchers are listed in Appendix H).

For plants, we searched the University of Arizona and University of Texas at El Paso (UTEP) herbaria databases for existing specimens from the monument. In the field we collected specimens whenever flowers or fruit were present on plants (Appendix A). All specimens that we collected and mounted were accessioned into the University of Arizona herbarium.

\section{Assessing Inventory Completeness}

We evaluated inventory completeness by (1) examining the rate at which new species were recorded in successive surveys (i.e., species accumulation curves; Hayek and Buzas 1997) and (2) by comparing the list of species we recorded with a list of species likely to be present based on previous research and/or expert opinion. For all species accumulation curves, we randomized the order of the sampling periods to break up clusters of new detections that resulted from temporal conditions (e.g., monsoon initiation) independent of cumulative effort. We used the computer program Species Richness and Diversity III (Pisces Conservation Ltd., IRC House, Pennington, Lymington, UK) to calculate species accumulation curves.

\section{Technical Concepts}

\section{Sampling Design}

Sampling design is the process of selecting sample units from a population or area of interest (for a review, see Thompson [1992]). Random samples allow inference to the larger population from which those samples were drawn, and estimate the true value of a parameter. Non-random samples are less likely to be representative of the entire population, because the sample may (intentionally or not) be biased toward a particular characteristic, perhaps of interest or convenience.

We briefly address sampling design in each chapter. In general, our surveys were not randomly located because we were more interested in detecting the maximum number of species than in providing inference to a larger area. Thus, abundance estimates (relative abundance, useful as an index to true abundance) detailed in this report may be biased because we surveyed in areas likely to have high species richness; however, the nature or extent of that bias is difficult to characterize or quantify. If population estimates were a higher priority, avoiding this potential bias would have greater importance. 


\section{Estimates of Abundance}

Estimating population size is a common goal of biologists, generally motivated by the desire to reduce (e.g., pest species), increase (e.g., endangered species), maintain (e.g., game species) or monitor (e.g., indicator species) population size. Our surveys at the monument were generally focused on detecting species rather than estimating population size. In many cases, however, we present estimates of "relative abundance" by species, which is an index to population size; we calculate it as the number of individuals of a species recorded, scaled by survey effort. Some researchers (particularly plant, marine, and invertebrate ecologists) prefer to scale such frequency counts by the number of observations of other species, which provides a measure of community dominance; abundance relative to other species present. If we completed multiple surveys in comparable areas (e.g., anywhere within the monument), we included a measure of precision (usually standard error) with the mean of those survey results.

Indices of abundance are presumed to correlate with true population size but do not typically attempt to account for variation in detectability among different species or groups of species under different conditions. Metrics (rather than indices) of abundance do consider variation in detection probability, and these include density (number of individuals per unit area; e.g., two black-throated sparrow per hectare of semi-desert grassland), and absolute abundance (population size; e.g., 15 black-tailed rattlesnakes at the monument). These latter techniques are beyond the scope of our research. While it is true that indices to abundance have often been criticized (and with good reason, c.f. Anderson 2001), the abundance information that we present in this report is used to characterize the commonness of different species rather than to quantify changes in abundance through space (e.g., habitat-use studies) or time (e.g., monitoring). As such, relative abundance estimates are more useful than (1) detectability-adjusted estimates of density for only a few species or (2) raw count data for all species without scaling counts by search effort. For a review of methods used to estimate abundance, see Lancia et al. (1996). 


\section{Chapter 2: Monument Overview}

\section{Monument Area and History}

Gila Cliff Dwellings National Monument (NM) is located approximately $75 \mathrm{~km}$ northwest of Silver City, New Mexico (Fig. 2.1). The monument includes sections of both the West and Middle forks of the Gila River and is surrounded by the Gila National Forest and Gila Wilderness, both administered by the U.S. Forest Service (USFS). The area is sparsely inhabited and the monument is located at the end of a minor highway that connects the monument to Silver City and the town of Mimbres, New Mexico. Recent annual visitation at the monument has exceeded 53,000 (NPS 2004).

Gila Cliff Dwellings NM was established in 1907 to preserve $15^{\text {th }}$ century Mogollon cliff dwellings. The USFS originally managed the monument, but control was transferred in 1933 to the National Park Service (NPS; Russell 1992). The administration of the monument shifted a number of times in the $20^{\text {th }}$ Century between the NPS and USFS, but as of early 2003, an NPS Park Superintendent, who works closely with USFS staff, has managed the monument.

When originally founded, the monument encompassed 65 ha, but it was expanded to 215 ha (with 43 ha of joint USFS/NPS area) in 1962 (Russell 1992). The monument consists of two separate units: the West unit is 194 ha and consists of the "contact station" and the cliff dwellings (Fig 2.2). The "TJ Ruins" unit is 21 ha and is adjacent to the joint USFS/NPS visitor center. We conducted few surveys at the TJ Ruins unit because of access issues to the site, particularly in 2002. Therefore, most study sites were in the main unit.

\section{Natural Resources Overview}

\section{Physiography, Geology, and Soils}

Gila Cliff Dwellings NM and the associated Gila Wilderness are located in the Rocky Mountains Volcanic Province. Elevation at the monument ranges from approximately 1,700 to $1,900 \mathrm{~m}$. The monument and surrounding wilderness lie within a large caldera that collapsed approximately 28 million years ago due to an enormous volcanic eruption (USFS 2003). Plateaus dominated by rhyolite, andesite, basalt, and welded tuffs are interbedded with Gila Conglomerate, while shallow floodplain deposits characterize the valleys. Soils derive predominantly from the Tertiary volcanics of the area. Volcanism in the area continues today, as demonstrated by the presence of geothermal springs (with water temperatures ranging from $32-65^{\circ} \mathrm{C}$ ) such as Lightfeather Hotsprings, located approximately $0.8 \mathrm{~km}$ upstream of the monument's headquarters (Sprouse et al. 2002).

\section{Hydrology}

The Continental Divide rises along the eastern boundary of the Gila Wilderness, and the Gila River's West and Middle forks, straddled by the monument, drain $4,200 \mathrm{~km}^{2}$ of the southern Rocky Mountains at an average rate of $5 \mathrm{~m}^{3} / \mathrm{s}$ (Sprouse et al. 2002). Flooding is significant and recurrent, with major erosion events, particularly after thawing of the snowmelt each spring. In the canyon that contains the monument's namesake cliff dwellings, there is a similarly named perennial spring, Cliff Dweller Canyon Spring.

\section{Climate}

Gila Cliff Dwellings NM experiences an annual bimodal pattern of precipitation which is characterized by heavy summer (monsoonal) storms from the Gulf of Mexico, and less intense frontal storms from the Pacific Ocean in the winter. On average, approximately one-half of the annual precipitation falls from July through September (Table 2.1; WRCC 2004). The area's hot season occurs from April through October; maximum temperatures in July can exceed $35^{\circ} \mathrm{C}$. Winter temperatures are cold and snow is common.

Average annual precipitation totals during the course of our study were similar in the two 


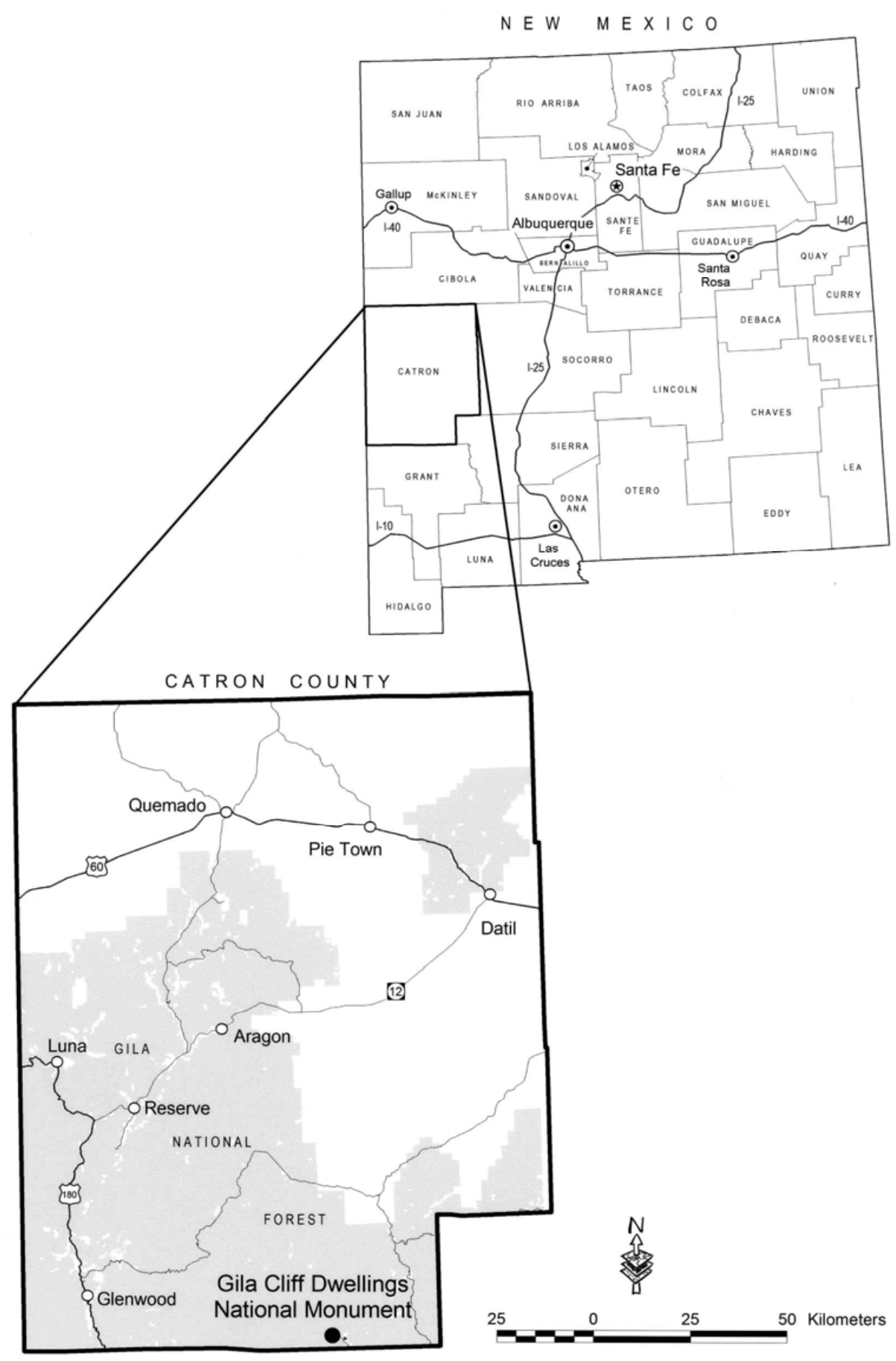

Figure 2.1. Location of Gila Cliff Dwellings NM in western New Mexico. 


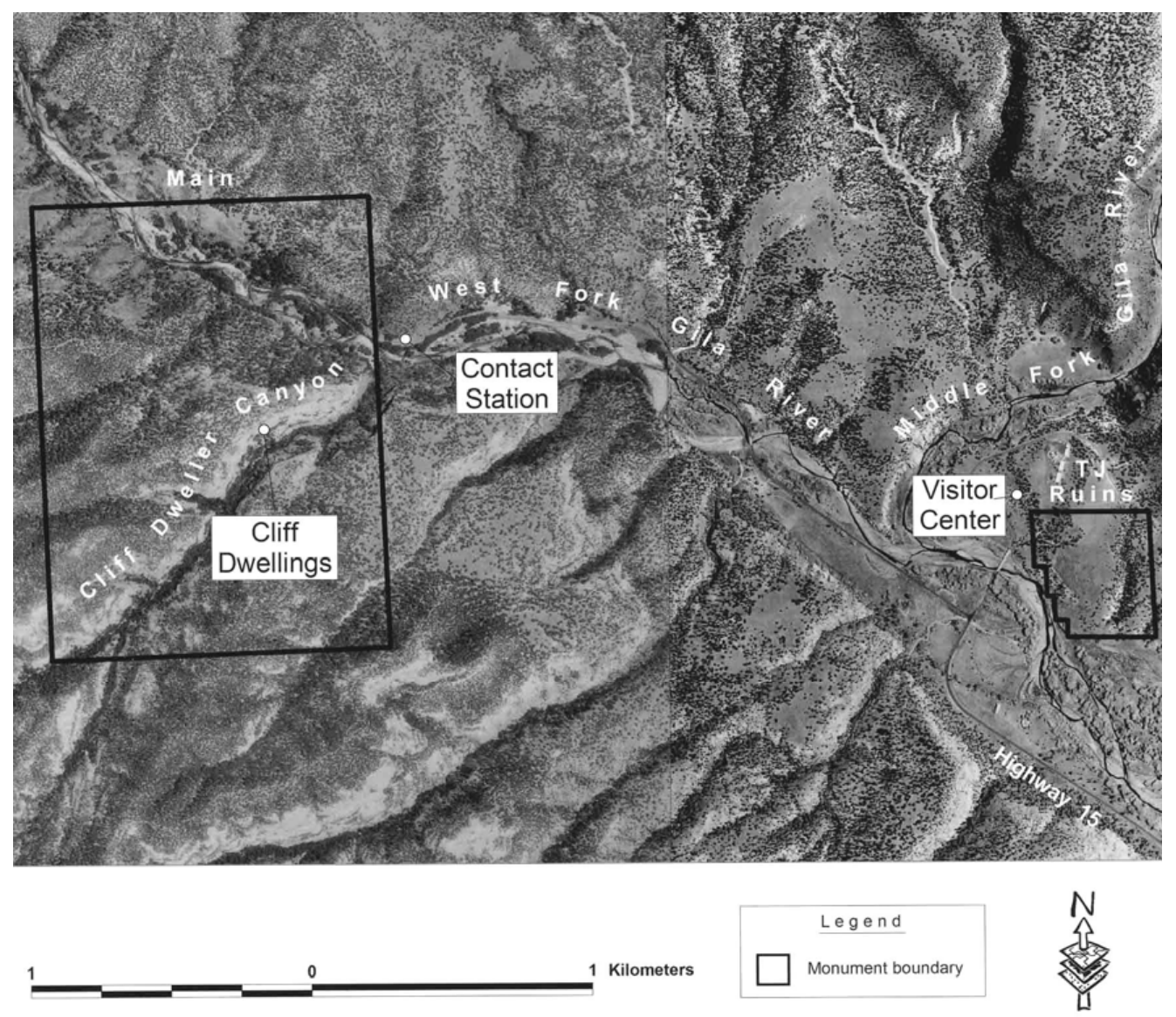

Figure 2.2. Study area and monument boundaries, Gila Cliff Dwellings NM. Digital Orthophoto Quarter Quad image from 1996.

years $(31.9 \mathrm{~cm}$ in 2001 and $32.2 \mathrm{~cm}$ in 2002) but well below the long-term mean of $40.7 \mathrm{~cm}$ (Fig. 2.3; WRCC 2004). In the fall of 2000, rainfall was above average (Fig. 2.3); this rain may have increased annual plant seed germination and growth prior to our 2001 plant surveys. Average annual temperatures during both years of our study were slightly below the long-term mean of $11.61{ }^{\circ} \mathrm{C}\left(11.37\right.$ and $11.35^{\circ} \mathrm{C}$ in 2001 and 2002 , respectively; WRCC 2004).

\section{Vegetation}

Vegetation at the monument consists of Madrean evergreen woodland with oaks, pinyon, and juniper on the mesa above the cliff dwellings and on the south-facing slopes of the TJ Ruins unit; coniferous forests of ponderosa pine and Douglas fir on the north-facing slopes and in Cliff Dweller
Canyon; and deciduous riparian vegetation consisting of narrowleaf cottonwood, ash, and walnut in the canyon bottoms and on the floodplain of the West Fork of the Gila River (see Figure 2.4).

\section{Other Inventories - Fish Surveys}

We did not survey for fish because of an active monitoring program by New Mexico Game and Fish Department from 1988-present on both the West and Middle forks of the Gila River (reviewed in Propst 2000). On the West Fork site (in the monument boundary) there have been seven species of native fishes and five species of non-native fishes observed. The most abundant species at the site were the native speckled dace (Rhinichthys osculus) and Sonora sucker (Catostomus insignis). Other native species were 
Table 2.1. Average monthly climate data for Gila Hot Springs, New Mexico, 1915-2004. Data from WRCC (2004).

\begin{tabular}{lccccccccccccc}
\hline & \multicolumn{10}{c}{ Month } \\
\cline { 2 - 12 } Characteristic & Jan & Feb & Mar & Apr & May & Jun & Jul & Aug & Sep & Oct & Nov & Dec & Annual \\
\hline Maximum temperature $\left({ }^{\circ} \mathrm{C}\right)$ & 12.6 & 14.8 & 17.8 & 22.3 & 26.7 & 31.4 & 31.4 & 29.8 & 27.7 & 23.2 & 17.3 & 12.7 & 22.3 \\
Minimum temperature $\left({ }^{\circ} \mathrm{C}\right)$ & -7.6 & -6.0 & -3.9 & -1.1 & 2.4 & 6.7 & 12.1 & 11.7 & 7.6 & 1.2 & -4.5 & -7.4 & 0.9 \\
\hline Precipitation $(\mathrm{cm})$ & 2.4 & 2.3 & 2.1 & 1.2 & 1.3 & 1.7 & 7.1 & 7.8 & 5.1 & 3.9 & 2.4 & 3.4 & 3.4 \\
\hline
\end{tabular}
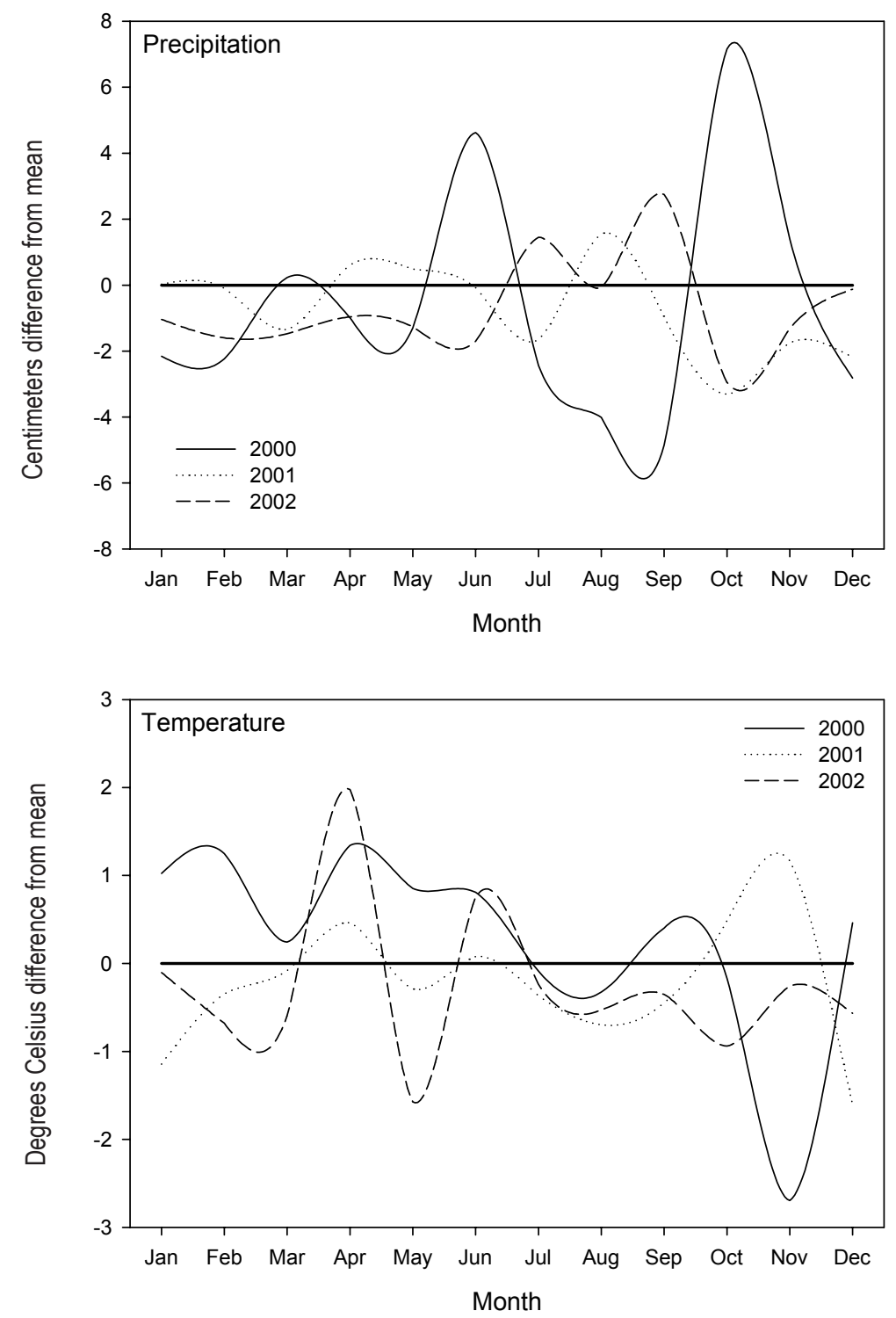

Figure 2.3. Comparison of monthly weather data during the time of the inventory (20002002) compared to the mean (1915-2004; thick solid line in both figures), Gila Hot Springs, New Mexico. Data from WRCC (2004). 
longfin dace (Agosia chrysogaster), roundtail chub (Gila robusta), spikedace (Meda fulgida), loach minnow (Tiaroga cobitis), and desert sucker (Catostomus clarki). The loach minnow and spikedace are listed as Threatened under the Endangered Species Act by the US Fish and Wildlife Service, and the roundtail chub is being considered for coverage under the Endangered Species Act (BISON 2004). Non-native fish species found in the monument were: rainbow trout (Oncorhynchus mykiss), brown trout (Salmo trutta), yellow bullhead (Ameiurus natalis), western mosquitofish (Gambusia affinis), and smallmouth bass (Micropterus salmoides). All non-native species were rare or uncommon in all years with only the rainbow trout observed in each survey year (Propst 2000). Although densities of all fish were highly variable among years, there did not appear to be declines of native fish populations.

At the Middle Fork site near the TJ Ruins unit, monitoring of fish populations found significant declines of most native species (Propst 2000). At that site there were seven native (same species as at the West Fork site) and eight nonnative species (all of the species at the West Fork site and flathead minnow [Pimephales promelas], green sunfish [Lepomis cyanellus], and bluegill [Lepomis macrochirus]). The proportion of native fish in the community declined from a high of $94 \%$ in 1988 to a low of $15 \%$ in 1999 (Propst 2000). Densities of the non-native yellow bullhead and smallmouth bass increased dramatically during that time.

\section{Natural Resource Management Issues}

Gila Cliff Dwellings NM is located at the end of a two-lane access road and is surrounded by wilderness. As a result, the monument likely has the fewest number of human-encroachment-related threats to its natural resources of any park unit in the Sonoran Desert Network (Hubbard et al. 2003). However, there have been only qualitative assessments of the threats to the monument's resources (Russell 1992). The U.S. Forest Service has not permitted cattle grazing on a large area of the Gila Wilderness adjacent to the monument since 1952. Although the monument is buffered from many natural resource problems found in other park units, there are a number of issues that require attention (Steve Riley, pers. comm.).

\section{Visitor Use}

Visitor use at the monument has steadily increased each year, causing monument staff to call for a study of visitor carrying capacity (NPS 1987). Staff have expressed concern that visitors are causing direct damage to the dwellings by climbing on, leaning on, and touching them and indirect damage by generating vibrations (Russell 1992). No visitor impact study has been undertaken and damage to the cliff dwellings is still a significant management concern (Steve Riley, pers. comm.).

Visitors may also be harming natural resources such as soil stability and vegetation structure through off-trail hiking and trampling; erosion has occurred on the steep slopes along the trails to the cliff dwellings (NPS 1987). It is unknown whether visitor and maintenance activities along the trails and in the sensitive riparian area affect animal movement patterns, but monument staff and volunteers have long been concerned about the protection of the black-tailed rattlesnakes along the trail to the cliff dwellings (Emily Bennett, pers. comm.). This concern was heightened in 2001 when a visitor killed a blacktailed rattlesnake along the trail.

Other disturbances from visitors may include disruption of bird nesting activities. Continual disturbances (e.g., from nearby recreational hiking) may cause some bird species to alter their activity and feeding patterns, and even to abandon their nests or fail to defend the nest against predators (Hockin et al. 1992, Theobald et al. 1997, Swarthout and Steidl 2003). The presence of humans can alter activity patterns of other wildlife as well, especially medium- and large-sized mammals. Visitors may also introduce non-native plant species by dispersing seed attached to clothing or automobiles.

\section{Forest Fires}

Two fires have burned in and around the monument in the last ten years and there is potential for an extreme fire in the area (NPS 2003). Fires can damage sensitive cultural sites, 

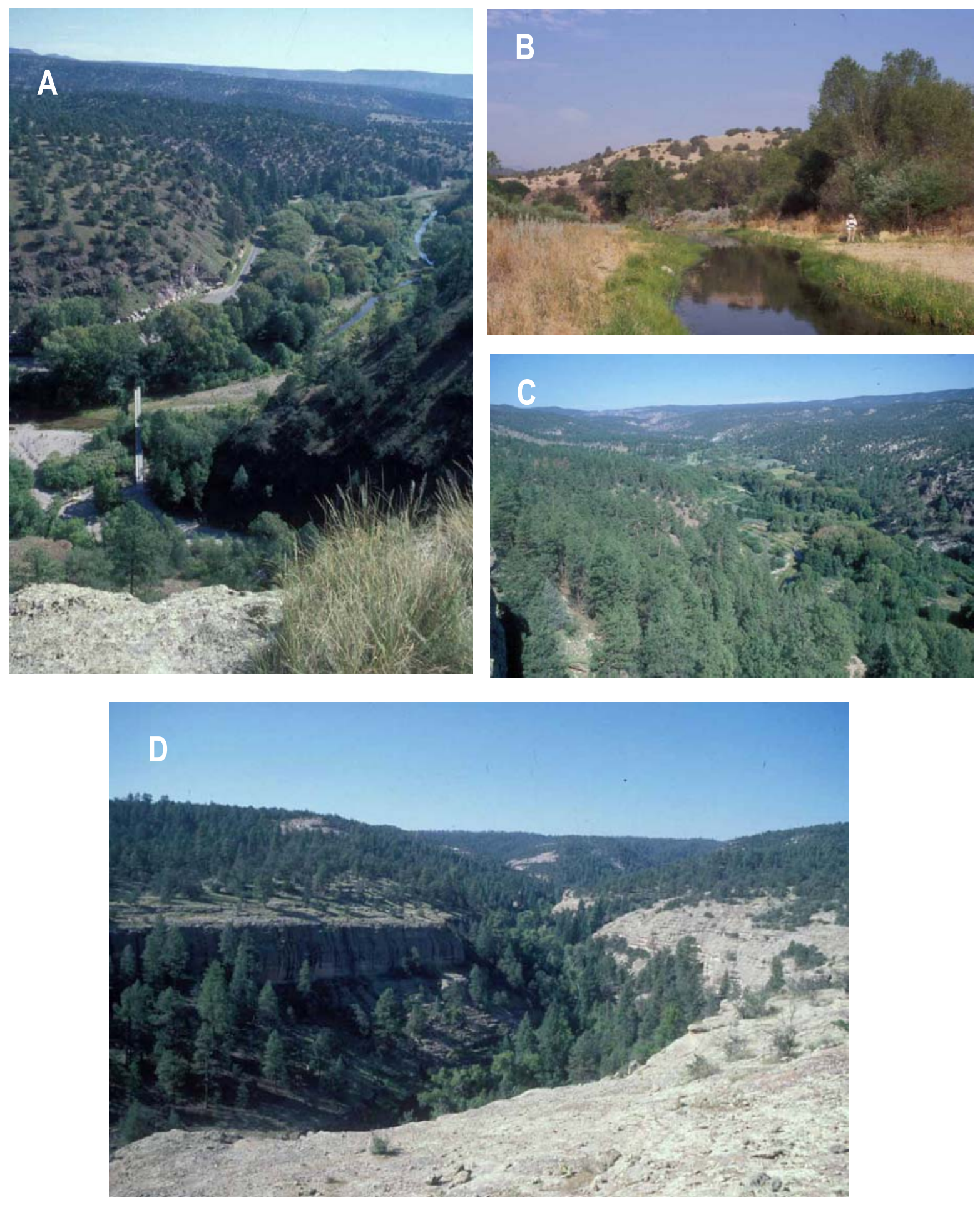

Figure 2.4. Photographs of Gila Cliff Dwellings NM. $A=$ looking at the main access road and foot bridge crossing the West Fork of the Gila River; $B=$ Middle Fork of the Gila River upstream of the visitor center; $\mathrm{C}=$ looking northwest along the West Fork of the Gila River with dense Ponderosa pine forest in the left foreground and riparian vegetation in the valley bottom; $D=$ looking southwest into Cliff Dweller Canyon from the ridge above the cliff dwellings. 
cause air quality problems, and lead to soil erosion (NPS 2003). They can also increase sediment flow, causing fish mortalities (Rieman and Clayton 1997). Yet fire is a natural part of the ecosystem and implementation of historic fire regimes may have an overall long-term positive impact on the ecosystem. The monument recently completed a fire management plan (in cooperation with the Gila National Forest; NPS 2003).

\section{Air Quality}

Smoke from forest fires can adversely affect the air quality at the monument (Russell 1992), but no monitoring data exist for these pollutants at the monument. Air quality affects plant communities by altering regeneration, species composition, and productivity (Coulston et al. 2004). Poor air quality can also restrict views from the monument (Russell 1992).

\section{Non-native Species}

The monument and surrounding lands have lacked a list of non-native plants and animals until this inventory effort. There are a number of fish species that are federally threatened or are "species of concern" at the monument, including spikedace
(Meda fulgida), speckled dace, longfin dace (Agosia chrysogaster), Loach minnow (Tiaroga cobitis), Sonora sucker, and roundtail chub (Gila robusta) (Propst 2000). These species may be negatively impacted by several non-native fish species known to be present at the monument, such as yellow bullhead and smallmouth bass (Propst 2000; see Fish Surveys above). Non-native fish compete with native species for food and space, adding to the decline of many native species (e.g., Propst and Bestgen 1991). American bullfrogs, a non-native amphibian, may also be negatively impacting native amphibian, reptile, and fish species (see Chapter 4 for more details).

\section{Aircraft Noise}

Commercial and low-flying military and emergency aircraft pass over the monument occasionally (Russell 1992, NPS 1994). Vibrations from these aircraft may damage the walls of the dwellings (Russell 1992). Both vibrations and noise generated by these aircraft may also affect the natural quiet and wildlife at the monument (NPS 1994). Aircraft overflights can produce changes in the physiology and behavior of some wildlife species (Luz and Smith 1976, Weisenberger et al. 1996). 


\section{Chapter 3: Plant Inventory}

\section{Previous Research}

To our knowledge, the only other plant inventory work at or near the monument took place in the mid 1970s when Sherman Lambert, then a graduate student at UTEP, collected specimens (reviewed in Appendix A). He collected plants representing a variety of growth forms (trees, shrubs, forbs, and grasses) but did not collect some of the most common plants of the area (e.g., ponderosa pine). Because there was no documentation for his study we attempted to contact Mr. Lambert but were unsuccessful. The most complete collection (204 species) from Lambert's study is at the UTEP herbarium, but some duplicate specimens currently reside at the monument. We obtained data about the UTEP herbarium's collection from the monument, but made no attempt to validate species identifications (see Chapter 8). We evaluated the duplicate specimens at the monument for possible accessioning into the University of Arizona herbarium but the specimens were in poor condition. We found no specimens from the monument in the University of Arizona herbarium.

\section{Methods}

We surveyed for plants by general botanizingopportunistically collecting plants when they were flowering or fruiting (when possible). We also sampled vegetation associated with VCP bird stations (see Chapter 5 for methods).

For this report, statistics such as the number of species collected or percentage of nonnative species exclude specimens that we could not identify to species $(n=27)$ unless there were no other specimens identified to species for that genus ( $n=4$; e.g., Cyperus sp.; Appendix A). We report multiple subspecies and/or varieties as "species" in the summary statistics. However, occasionally we collected a specimen that was identified to species and a specimen that was identified by subspecies (e.g., Oenothera caespitosa). Barring additional information, we consider these to represent two species. Finally, comparing our results to the collection at UTEP, five species were common to both studies where each species is represented by a specimen identified to species and a specimen identified to subspecies or variety (e.g., Frangula betulifolia). Without any additional information, we consider these to be separate species in our analyses.

\section{Spatial Sampling Designs}

General botanizing surveys were a mixture of intensive surveys and opportunistic collecting. A crew of up to three individuals intensively surveyed and collected in all areas of the monument (both units) for up to three days in 2001. In 2001 and 2002 we opportunistically collected specimens along the most traveled routes. We conducted a three-day survey in 2003 that covered most areas of the monument. We also collected species in areas outside the monument, particularly along the road leading to the monument and near the visitor center. We include these species in the flora of the monument because they may have been present in the monument, but the collector first observed and collected it outside of the monument.

\section{General Botanizing}

\section{Field Methods}

Whenever possible we collected at least one representative specimen (with reproductive structures) for each plant species that we encountered. We also maintained a list of species observed but not collected. This list, along with the list of collected species, comprises a "flora" for the monument (Appendix A). When we collected a specimen, we assigned it a collection number and recorded the flower color, associated dominant vegetation, date, collector names, and UTM coordinates. We pressed and processed the specimens on site. Specimens remained pressed for two to three weeks and were later frozen for 48 hours or more to prevent infestation by insects and pathogens. Mounted specimens were accessioned into the University of Arizona herbarium. 
Effort

We collected or recorded species on 66 days during the course of 12 months: March and May to September 2001, May to September 2002, and June 2003 (Table 3.1). The intensity of surveys ranged from two trips (with up to three field personnel for up to three days) to a single species collected in a day. Emily Bennett, naturalist in residence, collected 161 species in 52 days of collecting. Most of our collecting was opportunistic; although we had extraordinary spatial and temporal coverage, this type of collecting precludes quantifying survey effort.

\section{$\underline{\text { Analysis }}$}

We present a variety of summary statistics: total number of species found and number and percent of native and non-native species. To estimate inventory completeness we graph the number of new species by the month and year of their first collection.

\section{Results and Discussion}

We found 388 species in 2001-2003 (Appendix A). All but 12 species were collected within the monument boundary, and of those 12 species, we collected 11 within $1 \mathrm{~km}$ of either unit. Compared to the UTEP collection, we found 264 species (including 24 non-native species), which had not been collected previously for the monument. There were 123 species (including eight nonnative species) common to both collections, and 84 species (including five non-native species) unique to the UTEP collection. Of those that we did not find, 4 species are shrubs or trees (common hoptree, Mexican cliffrose, fragrant sumac, and dewstem willow) and others can take the form of subshrubs. We found no ornamental species (i.e., planted for landscaping). The percentage of nonnative species was higher for our study $(8.5 \%)$ than for the UTEP collection (6.3\%) though we don't know if Steve Lambert did a comprehensive inventory. Based on the two collections, a total of 471 species (including 33 non- native species) have been recorded in the monument and surrounding lands. These results indicate high species richness of plants for such a small park unit at its elevation and geographic location.

Plant species richness plays an important role in determining the diversity of the other taxonomic groups that we studied, particularly amphibians, birds, and small mammals (see respective chapters for additional information). The diversity of the plant species is due to the diversity of soil conditions, microsites (from floodplain on the West Fork of the Gila River to the shady Cliff Dweller Canyon to the open mesa tops), and availability of water.

We did not find four species of rare or endangered plants that may occur in the area (based on Sivinski and Lightfoot 1992): Hess' fleabane (Erigeron hessii) is known from the Gila Wilderness, and Chenopod brickellbush (Brickellia chenopodina), Gila manroot (wild cucumber; Marah gilensis), and Penstemon linaroides ssp. maquirei are all known from the Gila River Valley.

Table 3.1. Field survey effort for general botanizing surveys, Gila Cliff Dwellings NM, 2001-2003.

\begin{tabular}{|c|c|c|c|}
\hline Year & Month & Number of collection days & Number of species collected/observed \\
\hline \multirow{6}{*}{2001} & March & 1 & 13 \\
\hline & May & 3 & 216 \\
\hline & June & 7 & 27 \\
\hline & July & 9 & 53 \\
\hline & August & 6 & 94 \\
\hline & September & 2 & 8 \\
\hline \multirow[t]{5}{*}{2002} & May & 2 & 5 \\
\hline & June & 5 & 12 \\
\hline & July & 5 & 8 \\
\hline & August & 15 & 54 \\
\hline & September & 8 & 37 \\
\hline 2003 & June & 3 & 101 \\
\hline
\end{tabular}




\section{Inventory Completeness}

Despite consistent collecting, concentrated in a two-year-period (2001 and 2002), it appears, based on the species accumulation curve, that we did not reach the goal of documenting $90 \%$ of the species at the monument (Fig. 3.1). The numbers of new species that we collected after the start of monsoons (early July) were roughly equal in 2002 and 2001, indicating that additional surveys during a post-monsoon period with above-average rainfall would likely yield many additional species for collecting.

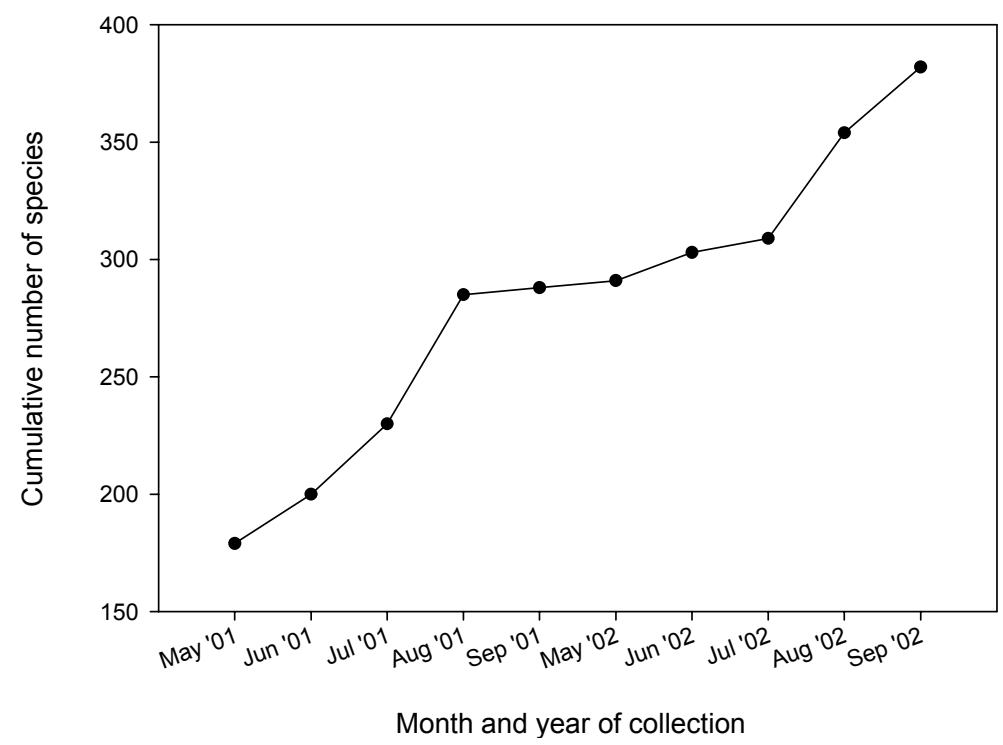

Figure 3.1. Species accumulation curve for the number of new plant species collected by month and year of the most intensive collections, Gila Cliff Dwellings NM, May-September2001 and 2002. Figure excludes minor collecting that took place in March 2001 (11 species) and June 2003 (6 species). 


\section{Chapter 4: Amphibian and Reptile Inventory}

\section{Previous Research}

To our knowledge, previous work related to amphibians and reptiles ("herpetofauna") at Gila Cliff Dwellings NM is limited to the brief survey of the area by Hayward and Hunt (1972). There have been some specimens collected in the area (see Appendix I). Painter (1985) studied herpetofauna throughout the region and compiled museum records from New Mexico State University, Western New Mexico University, and University of New Mexico.

\section{Study Area}

Due to the relatively small size of the monument, we expanded the boundaries of our study area to include the watershed of Cliff Dweller
Canyon (Fig. 4.1). Because management of the surrounding land is similar to that of the monument, we enlarged the study area to allow a greater number of survey plots and routes to increase the likelihood of detecting species that are present in the monument (e.g., snakes with large home ranges may regularly move across the monument boundaries) and provide more precise estimates of relative abundance (see Chapter 1). All species we recorded in this expanded study area were also recorded within the legislated monument boundaries.

\section{Methods}

We surveyed for herpetofauna in 2001 and 2002 using four methods representing plot-based and more flexible, non-plot-based methods (Table 4.1).

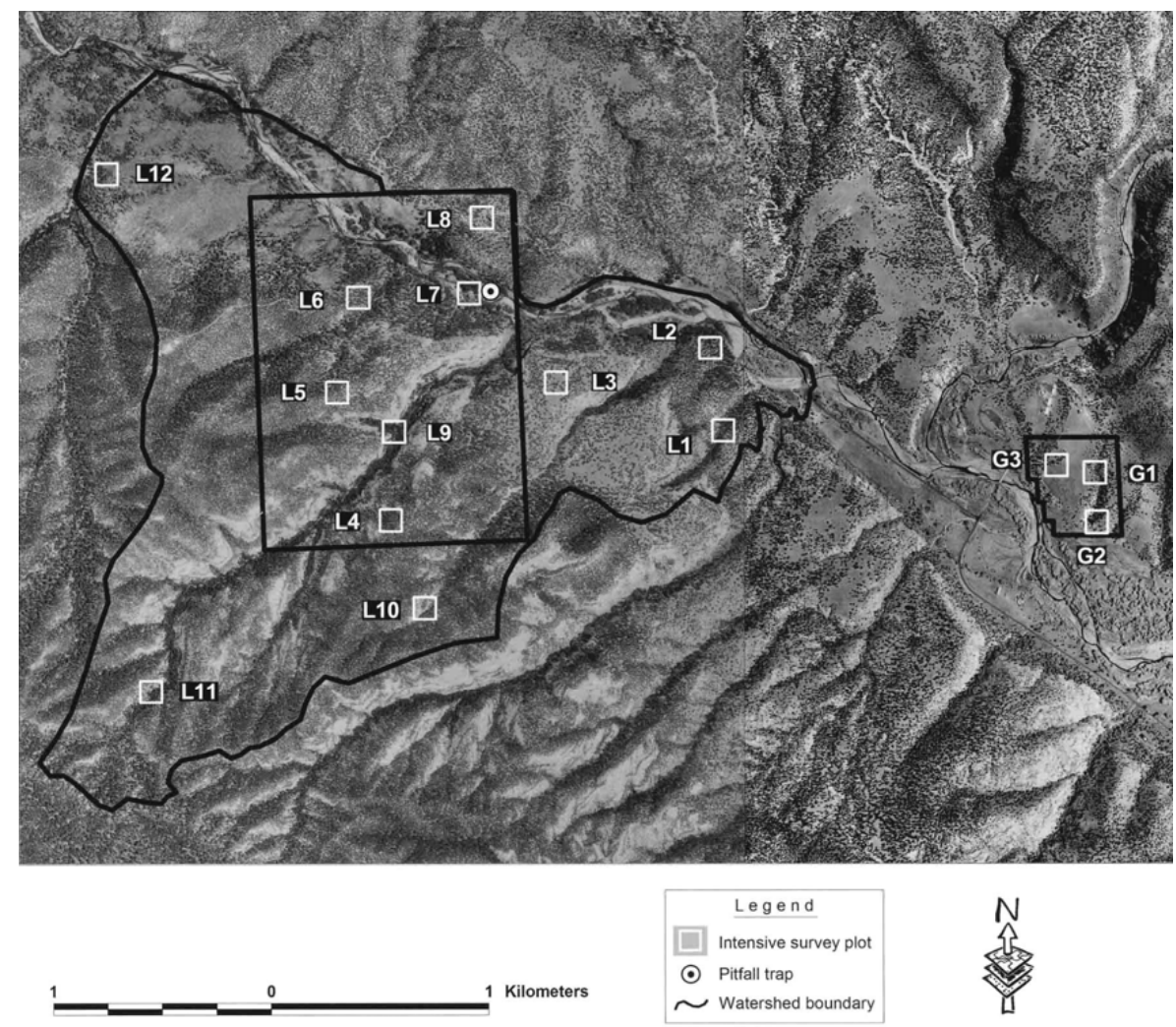

Figure 4.1 Survey plot locations for herpetofauna, Gila Cliff Dwellings NM, 2001 and 2002. 
Table 4.1. Herpetofaunal survey effort by method, Gila Cliff Dwellings NM, 2001 and 2002.

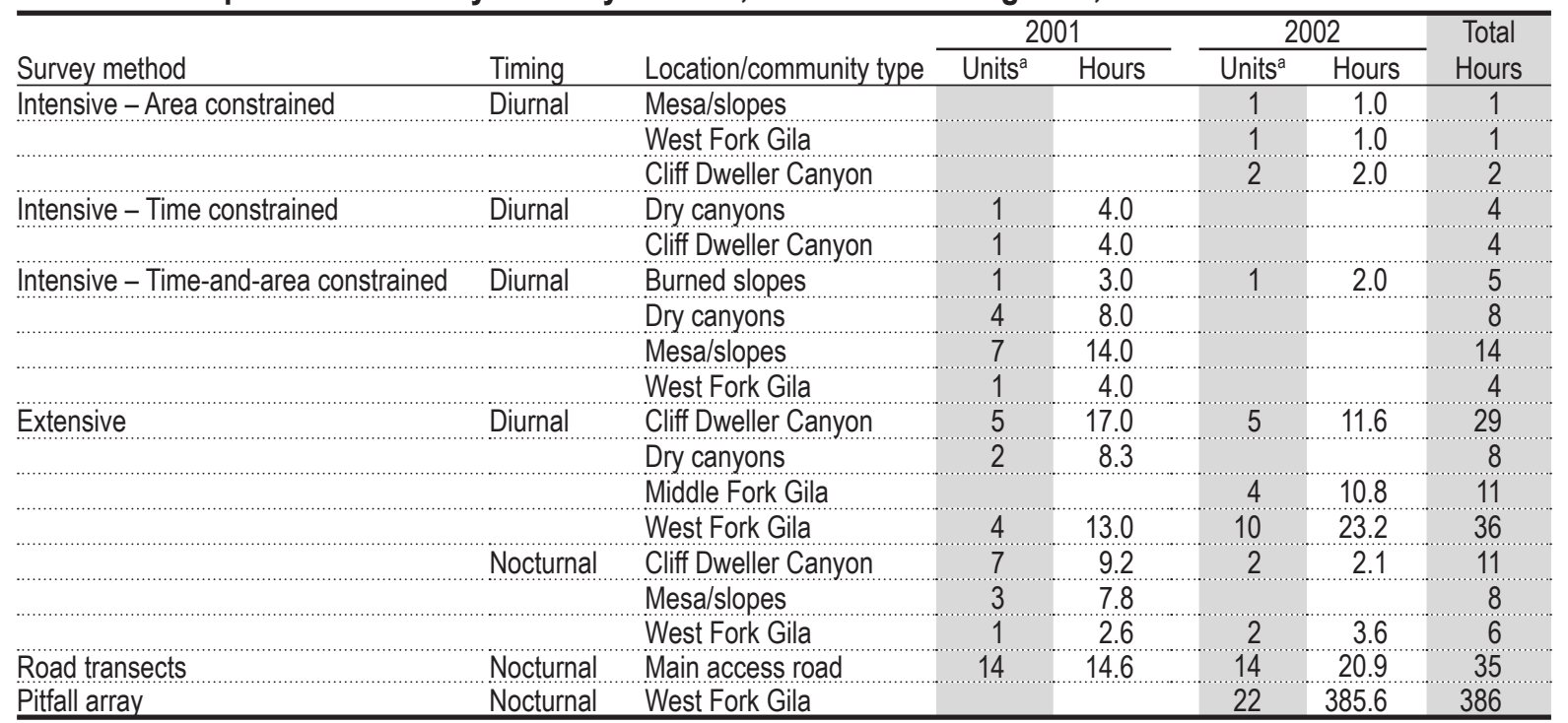

a Survey units: number of surveys for extensive and road surveys, number of nights for pitfall array, and number of plots for intensive surveys (1 hour duration).

The latter approach allowed observers to respond to environmental conditions, such as temperature and precipitation, and adjust search time, intensity, and location accordingly. This flexibility was important for detecting rare, elusive, or ephemeral species most likely missing from existing records. We used non-plot-based methods diurnally and nocturnally in an effort to detect species with restricted periods of activity (Ivanyi et al. 2000). We consider amphibians and reptiles together in this report because we used the same search methods for both groups.

\section{Notes on Species Identifications}

Whiptail lizards (Cnemidophorus [Aspidoscelus by some sources] spp.) are notoriously difficult to identify in the field because of the similarity in appearance for several sympatric species (Stebbins 2003). Many parthenogenetic (non-sexually reproducing) whiptails may have arisen as hybrids from the same diploid, sexually reproducing parent species (Degenhardt et al. 1996). Several undescribed "parthenospecies" may exist in the desert Southwest (Wright and Vitt 1993, Cole and Dessauer 1994). Of the whiptails that we found, adults commonly had many spots and greenish/ blue tails while juveniles had few to no spots and orange tails; we considered all of these to be
Chihuahuan spotted whiptails. We recorded a few $(n=6)$ unknown whiptails, which were likely juvenile Chihuahuan spotted whiptails. Although the desert grassland whiptail may be present in the area (Degenhardt et al. 1996, Appendix E), our survey crews were familiar with the appearance of this species and are likely to have recognized it if seen.

\section{Spatial Sampling Design}

For all methods, we surveyed for herpetofauna in preferential (non-random) locations because we wanted to detect as many species as possible. To determine locations for intensive survey plots, we examined a topographic map of the area and selected areas that represented the community types in the monument and surrounding USFS lands.

\section{Community Types and Locations}

We felt that it was important to compare herpetofauna communities among sites in and around the monument where possible. Because of extreme differences in environmental conditions (e.g., soils, vegetation, and aspect) in the area and the difficulty in delineating these environmental boundaries, we established a system for assigning 
animals, found during extensive surveys, to locations or community types. The following are descriptions of the locations/community types that we used:

- West Fork Gila River: perennial riparian area in the river bottom; dominated by narrowleaf cottonwood and other deciduous trees.

- Middle Fork Gila River: similar to West Fork but with less vegetation, more open pools, and warmer water due to hot spring.

- Cliff Dweller Canyon: shady, moist, southwest to northeast tending canyon with perennial water; dominated by walnut, oak, Douglas fir, and cottonwood.

- Mesa/Slopes: xeric, open forest of juniper and pinyon pine with rocky soils.

- Burned Slopes: similar to mesa/slopes but burned within the last 15 years; more open understory.

- Dry Canyons: all canyons except Cliff Dweller; dominated by ponderosa pine and oak.

\section{Intensive Surveys}

To provide a standardized survey method, we used visual encounter surveys (described by Crump and Scott [1994]) that were constrained by time (time-constrained searches; TCS), by area (area-constrained transects; ACS), and by both time and area (time-and-area constrained plots; TACS). The primary reason for completing intensive surveys was to use repeatable methods with consistent effort for precise estimation of the relative abundance of common species. For timeconstrained and time-area-constrained surveys, we visited each plot twice in a morning (with different observers) to increase the probability that a survey occurred during a period of peak activity for diurnal lizards. Inference to associated community type is speculative because plot location was selected subjectively rather than randomly. In 2002 we completed fewer intensive surveys because of the relatively low number of species and individuals recorded and instead focused our efforts on other methods, particularly extensive surveys (discussed later).

\section{Field Methods}

We recorded the starting and stopping endpoints for area-constrained transects using Garmin Emap GPS units, but we did not stake the endpoints with rebar. For other plots, we determined UTM coordinates for each of the four plot corners (and end points for time-constrained plots) using a Trimble GPS unit and marked the southwest corner of plots with rubber-capped rebar stakes. Because we did not want to place survey stakes in areas where they would be visible, we occasionally staked corners other than the standard southwest plot corner. At the start of each survey, regardless of method, we wrote a brief description of the vegetation and physical environment of the area. Before and after each survey we recorded weather information: temperature, relative humidity ( $\%)$, cloud cover $(\%)$, wind speed $(\mathrm{km} / \mathrm{h})$, and an overall description of the conditions. For each animal that we observed, we recorded species (using a four-letter code), sex and age class if known, and comments regarding characteristics or behavior of interest.

\section{Effort}

Area-constrained transects: Transects were 100 $\mathrm{m}$ in length and the observer searched $1.0 \mathrm{~m}$ on each side of and above (in vegetation) this line from 0900 to 1400 hours. A single observer visited each of the four transects twice for one-half hour, except for one Cliff Dweller Canyon transect that was visited only once and for one hour. A single observer completed all surveys from 13 June to 1 August 2002 ( $n=7$ visits).

Time-constrained searches: Although search area was constant between visits to a single plot (both plots were located in steep-sided canyons), survey area was difficult to quantify and varied among plots. Search time was constant among all surveys (1 person-hour), and each plot was visited twice in a morning (with different observers) from 0800 to 1215 hours, 27 and 28 May 2001 and 21 and 22 August $2001(n=8$ visits).

Time-area-constrained plots: These plots were all 1 ha $(100 \times 100 \mathrm{~m})$ in size, and one person completed each survey in one hour from 0730 to 1300 hours. We used Garmin E-map GPS units to 
ensure that we stayed within the plot boundaries during the search. We visited each plot $(n=13)$ twice in a morning (plot L12 three times), with different observers, from 26 to 30 May 2001. We returned to visit plot L07 twice on the morning of 21 August 2001, and plot L12 twice on the morning of 26 June 2002.

\section{Analysis}

We calculated species richness as the sum of species recorded, by community type, in each year, and we estimated relative abundance of species by community type in each year as the mean number of detections per survey (except for area-constrained transects, which were the mean number of detections per person hour), across all surveys.

\section{Extensive Surveys}

We designed extensive surveys to enable us to visit most areas of the monument and to search areas that, based on our field experience, were likely to have high species richness or species not previously recorded. Extensive surveys, a type of visual-encounter survey (Crump and Scott 1994), differed from intensive surveys in that they were not constrained by area or time. In 2002 we used this method almost exclusively because of its efficiency. In general, we focused extensive surveys during the cooler morning, evening, and nighttime periods to maximize the chance of encountering snakes and amphibians, which would likely be active during these times (Ivanyi et al. 2000), and as a complement to our intensive surveys, which more often occurred during the warmer late-morning and midday hours.

\section{Field Methods}

We used the extensive survey method for both diurnal and nocturnal surveys. Nocturnal surveys were defined as those beginning after 1700 hours, often including the crepuscular period. Search times varied from approximately 0.5 to 5.75 hours (mean $=2.4, \mathrm{SD}=1.3$ ) depending on conditions and logistical constraints. Before and after each survey we recorded weather information: temperature, relative humidity (\%), cloud cover $(\%)$, wind speed $(\mathrm{km} / \mathrm{h})$, and an overall description of the conditions. For each animal that we observed, we recorded species (using a four-letter code), sex and age class if known, and comments regarding characteristics or behavior of interest. We recorded UTM coordinates to define the boundaries of our search area or the path we followed during our surveys.

\section{Effort}

We spent 109 hours on 47 extensive surveys from 26 May to 23 August 2001 and from 26 June to 16 September 2002 (Table 4.1). Most of the surveys ( $n=29$ of 47 ) were initiated during the cooler evening, nighttime, or morning hours (0500 to 1000 hours). It is not possible to accurately quantify search effort (total number of person-hours of searching) because more than one observer participated in some searches, and observers were occasionally close enough to one another to influence findings (i.e., an observer may have recorded an animal that was flushed by another observer). Also, volunteer observers sometimes accompanied crew members; and although they likely increased the number of observations (by "foot flushing"), they were not as skilled at finding or identifying animals as were crew members.

\section{Analysis}

We calculated species richness as a count of species recorded by community type in each year (diurnal and nocturnal surveys combined), and we estimated relative abundance of species by community type in each year as the mean number of detections per survey hour (typically these were person-hours), across all diurnal and nocturnal surveys. It should be noted, however, that community type designations were applied to entire surveys based on where the majority of survey time was spent, and that community type was not established with the aid of a vegetation map. Thus some "West Fork" surveys, for example, included exploration of adjacent dry tributaries as well as the river's aquatic and riparian components. 
Pitfall Traps

Pitfall traps, a live-trap, passive sampling technique, is especially useful in detecting species that may be difficult to observe because of rarity, limited activity periods, or inconspicuous behavior (Corn 1994).

\section{Field Methods}

We constructed the pitfall trap array by placing three 19-L buckets roughly $8 \mathrm{~m}$ away and at angles of approximately 120 degrees each from a central bucket (Gibbons and Semlitsch 1981). Between buckets we dug shallow trenches in which we placed drift fences (7.6-m long, 0.5-m tall aluminum-flashing, supported with rebar) that connected each of the three outside buckets to the central bucket. Buckets were buried so that the lip of the bucket was at ground level. We placed cover boards (50 x $50 \mathrm{~cm}$ pieces of plywood) over the buckets to keep the animals cool during the day, to minimize mortality, and to attract additional animals (Corn 1994).

In an attempt to capture large snakes and other animals that are able to escape from pitfall trap buckets (Corn 1994); we placed one wiremesh funnel trap (tube with inwardly-directed cones at each end) at the midpoint along each side of the drift fences (total of six funnel traps). Animals entering via the funnels would fall to the bottom of the tube and be unable to escape. We typically opened the pitfall and funnel traps around sunset, then checked and closed the traps the next morning. For each animal captured, we recorded species, sex, and age class (if known).

\section{Effort}

We established one pitfall trap array (with four pitfall traps and six funnel traps) in the floodplain adjacent to the West Fork Gila River (Fig. 4.1). We operated the pitfall trap array for a total of 386 hours (22 nights) from 6 August to 16 September 2002 (Table 4.1).

\section{Analysis}

We report the total number of animals caught; numbers were too low to calculate relative abundance.

\section{Road Surveys}

Driving slowly on roads at night is recognized as an excellent method for surveying some groups of reptiles, particularly nocturnal snakes (e.g., Rosen and Lowe 1994). Before and after each survey we recorded weather information: temperature $\left({ }^{\circ} \mathrm{C}\right)$, relative humidity (\%), cloud cover $(\%)$, and wind speed $(\mathrm{km} / \mathrm{h})$. For each amphibian and reptile observed, we recorded species, sex and age class (if known), whether the animal was alive or dead, and location (as measured by distance from the start point of the survey). For all surveys we drove the same section of road from the visitor center to the contact station.

\section{Effort}

We completed 14 road surveys in both 2001 and 2002 (Table 4.1).

\section{Analysis}

We report the total number of animals observed during both years and for each year and calculate relative abundance of animals as the mean $( \pm \mathrm{SE})$ number of individuals per hour of survey.

\section{Incidental Observations}

In 2001 we recorded as incidentals all animals seen when observers were not actively surveying using other survey types. We modified our approach in 2002, however, to include amphibians and reptiles observed outside of formal surveys. In both years we recorded the species, sex and age class (if known), time of observation, and UTM coordinates of the animal. Incidental detections recorded by other survey crews (e.g., bird crew) and by the herpetofaunal crew in 2002 were not accompanied by route descriptions. We collected incidental observations from 25 April to 24 September 2001, and from 30 April to 16 September 2002. We also collected incidental sightings from monument staff and volunteers and made a concerted effort to ensure correct identifications by asking detailed questions about each unusual sighting.

\section{Effort and Analysis}

Because we did not quantify search effort with this method, we do not present an analysis of 
relative abundance nor compare results among species. Rather, we simply report the number of observations.

\section{Results}

We recorded three amphibian and 16 reptile species at Gila Cliff Dwellings NM (Appendix B) and an additional two reptile species within $5 \mathrm{~km}$ of the monument (Appendix E). Species recorded include the narrow-headed gartersnake and the Arizona toad, which are regionally recognized as "Sensitive" species (BISON 2004, see summary in Appendix B). The narrow-headed gartersnake is listed as threatened by the State of New Mexico.

\section{Intensive Surveys}

We recorded 10 species during intensive surveys; the fewest species $(n=0-2)$ in the Mesa/slopes and Burned Slopes community types and the most $(n=6)$ in the West Fork community type (Table 4.2, 4.3), though there was less sampling effort in that area (Table 4.1). The West Fork was the only area where we recorded snakes or the American bullfrog (Tables 4.2, 4.3). The ornate tree and eastern fence lizards were the most widespread species (based on their presence in all community types and areas) and were the most abundant in all areas except the West Fork, where the American bullfrog was most dominant. The crevice spiny and greater short-horned lizards were only recorded in the Mesa/slopes and Dry Canyon community types (Table 4.3).

\section{Extensive Surveys}

We recorded 13 species during 109 hours of extensive surveys (Table 4.4). We observed three species in all community types and in both years (crevice spiny, eastern fence, and ornate tree lizards), whereas we observed three species in only one community type (canyon treefrog, striped whipsnake, and narrow-headed gartersnake). Excluding results from dry mesas/slopes, species richness changed little among community types/ areas (eight or nine species) despite significant differences in the amount of time spent surveying in each community type/area. Survey effort in
Cliff Dweller Canyon in 2001 and 2002 was similar (Table 4.1), yet species composition between years was very different. Of the total of nine species found in the canyon, only four were found in both years (Table 4.4). By contrast, we found only slight inter-annual differences in species composition along the West Fork of the Gila River. Despite a doubling of search effort in 2002 only one species (represented by one individual) was found in 2002 that was not found in 2001.

The American bullfrog in the Middle Fork area had the highest relative abundance of any species in all community types (Table 4.4). The Arizona toad and Chihuahuan spotted whiptail were also abundant on surveys along the Middle Fork. The American bullfrog and Arizona toad had a large standard error associated with their relative abundance estimates, however, indicating that their numbers were temporally variable. Despite being present in all but one community type/area, the Chihuahuan spotted whiptail reached a mean relative abundance that was five times higher along the Middle Fork than in any other area.

\section{Incidental Observations}

We recorded 18 species in the monument and two species outside of the monument by way of incidental observations (Table 4.4, Appendix E). Of these 20 species, five had not been recorded during the course of other surveys: eastern collared lizard, Clark's spiny lizard, ring-necked snake, mountain patch-nosed snake, and western box turtle.

\section{Pitfall Traps}

In almost 400 hours of pitfall trap operation, we caught only 31 animals representing four species: 28 Arizona toads, two Chihuahuan spotted whiptails, and one western terrestrial gartersnake.

\section{Road Surveys}

We found five species during 28 road surveys (Table 4.5). The number of species found on each survey ranged from zero to three $($ mean $=1.3, \mathrm{SD}$ $=1.05$ ). We found no animals on seven surveys. 
Table 4.2. Number of observations $(\mathrm{N})$ and relative abundance (mean $\pm \mathrm{SE}$ ) of herpetofauna detected during area-constrained transects and time-constrained searches, Gilā Cliff Dwellings NM, 2001 and 2002. See Table 4.1 for search effort used in calculating relative abundance.

\begin{tabular}{|c|c|c|c|c|c|c|c|c|c|c|}
\hline \multirow[b]{3}{*}{ Species } & \multicolumn{5}{|c|}{ Area-constrained transects $(2002)^{a}$} & \multicolumn{5}{|c|}{ Time-constrained searches (2001) } \\
\hline & \multirow[b]{2}{*}{$\mathrm{N}$} & \multicolumn{2}{|c|}{$\begin{array}{l}\text { West Fork } \\
\text { Gila River }\end{array}$} & \multicolumn{2}{|c|}{$\begin{array}{c}\text { Cliff Dweller } \\
\text { Canyon }\end{array}$} & \multirow[b]{2}{*}{$\mathrm{N}$} & \multicolumn{2}{|c|}{ Dry canyons } & \multicolumn{2}{|c|}{$\begin{array}{c}\text { Cliff } \\
\text { Dweller Canyon }\end{array}$} \\
\hline & & Mean & SE & Mean & SE & & Mean & SE & Mean & $\mathrm{SE}$ \\
\hline Arizona toad & 5 & 2.5 & 2.50 & & & 3 & 0.3 & 0.25 & 0.5 & 0.50 \\
\hline American bullfrog & 11 & 5.5 & 1.50 & & & & & & & \\
\hline eastern fence lizard & & & & & & 8 & 1.8 & 0.48 & 0.3 & 0.25 \\
\hline ornate tree lizard & 6 & 2.0 & 1.00 & 0.7 & 0.67 & 15 & 2.0 & 0.41 & 1.8 & 1.03 \\
\hline western terrestrial gartersnake & & & & & & 1 & & & 0.3 & 0.25 \\
\hline Species richness & & 3 & & & & & 3 & & & \\
\hline Total no. detections & & 2 & & & & & 10 & & & \\
\hline
\end{tabular}

a We found no animals in two surveys on the mesa/slopes.

Table 4.3. Number of observations $(\mathrm{N})$ and relative abundance (mean $\pm \mathrm{SE}$ ) of herpetofauna detected during time-and-area constrained searches, by community type, Gila Cliff Dwellings NM, 2001 and 2002. See Table 4.1 for search effort used in calculating relative abundance.

\begin{tabular}{|c|c|c|c|c|c|c|c|c|c|c|c|}
\hline \multirow[b]{3}{*}{ Species } & \multirow[b]{3}{*}{$\mathrm{N}$} & \multirow{2}{*}{\multicolumn{2}{|c|}{$\begin{array}{c}\text { West Fork Gila River } \\
2001\end{array}$}} & \multicolumn{4}{|c|}{ Burned Slopes } & \multirow{2}{*}{\multicolumn{2}{|c|}{$\frac{\text { Dry Canyons }}{2001}$}} & \multirow{2}{*}{\multicolumn{2}{|c|}{$\frac{\text { Mesas/slopes }}{2001}$}} \\
\hline & & & & \multicolumn{2}{|c|}{2001} & \multicolumn{2}{|c|}{2002} & & & & \\
\hline & & Mean & SE & Mean & SE & Mean & SE & Mean & SE & Mean & $\mathrm{SE}$ \\
\hline American bullfrog & 8 & 2.0 & 0.71 & & & & & & & & \\
\hline crevice spiny lizard & 6 & & & & & & & 0.6 & 0.38 & 0.1 & 0.07 \\
\hline eastern fence lizard & 69 & 0.8 & 0.48 & 8.3 & 0.67 & 6.0 & 2.00 & 1.6 & 0.63 & 1.1 & 0.48 \\
\hline ornate tree lizard & 58 & 1.5 & 0.50 & 1.3 & 1.33 & 1.5 & 0.50 & 3.9 & 0.74 & 1.0 & 0.51 \\
\hline greater short-horned lizard & 1 & & & & & & & & & 0.1 & 0.07 \\
\hline Chihuahuan spotted whiptail & 14 & 0.8 & 0.48 & & & 0.5 & 0.50 & 1.0 & 0.42 & 0.1 & 0.10 \\
\hline western terrestrial gartersnake & 6 & 1.5 & 0.50 & & & & & & & & \\
\hline black-tailed rattlesnake & 1 & 0.3 & 0.25 & & & & & & & & \\
\hline Species richness & & & & 2 & & 3 & & & 4 & & \\
\hline Total no. detections & & & & 2 & & 16 & & 5 & 7 & & \\
\hline
\end{tabular}

Table 4.4. Number of observations $(\mathrm{N})$ and relative abundance (mean $\pm \mathrm{SE}$ ) of herpetofauna detected during extensive surveys (diurnal and nocturnal surveys), by community type, and total number of incidental observations, Gila Cliff Dwellings NM, 2001 and 2002. See Table 4.1 for summary of effort.

\begin{tabular}{|c|c|c|c|c|c|c|c|c|c|c|c|c|c|c|c|c|}
\hline \multirow[b]{3}{*}{ Species } & \multirow[b]{3}{*}{$\mathrm{N}$} & \multicolumn{4}{|c|}{ Cliff Dweller Canyon } & \multicolumn{4}{|c|}{ West Fork Gila River } & \multirow{2}{*}{\multicolumn{2}{|c|}{$\begin{array}{c}\text { Middle Fork } \\
2002 \\
\end{array}$}} & \multirow{2}{*}{\multicolumn{2}{|c|}{$\frac{\text { Dry canyons }}{2001}$}} & \multirow{3}{*}{\multicolumn{2}{|c|}{$\begin{array}{c}\text { Mesas/ } \\
\text { slopes } \\
2001 \\
\text { Mean SE }\end{array}$}} & \multirow[b]{3}{*}{ Incidentals } \\
\hline & & \multicolumn{2}{|c|}{2001} & \multicolumn{2}{|c|}{2002} & \multicolumn{2}{|c|}{2001} & \multicolumn{2}{|c|}{2002} & & & & & & & \\
\hline & & Mean & $\overline{\mathrm{SE}}$ & Mean & SE & Mean & SE & Mean & SE & Mean & SE & Mean & SE & & & \\
\hline Arizona toad & 182 & & & 0.1 & 0.11 & 0.3 & 0.18 & 2.7 & 1.12 & 5.0 & 3.47 & & & 0.3 & 0.26 & 18 \\
\hline canyon treefrog & 1 & $<0.1$ & 0.03 & & & & & & & & & & & & & 3 \\
\hline American bullfrog & 211 & 0.1 & 0.06 & & & 3.0 & 1.95 & 1.0 & 0.38 & 11.6 & 5.19 & 0.2 & 0.17 & & & 64 \\
\hline eastern collared lizard & & & & & & & & & & & & & & & & 4 \\
\hline crevice spiny lizard & 33 & $<0.1$ & 0.05 & 0.4 & 0.16 & 0.2 & 0.12 & 0.1 & 0.07 & 0.5 & 0.24 & 0.2 & 0.17 & 1.3 & 0.25 & 10 \\
\hline Clark's spiny lizard & & & & & & & & & & & & & & & & 3 \\
\hline eastern fence lizard & 137 & 0.9 & 0.25 & 0.8 & 0.30 & 2.3 & 1.04 & 1.3 & 0.36 & 0.1 & 0.13 & 1.3 & 0.10 & 0.9 & 0.12 & 72 \\
\hline ornate tree lizard & 222 & 2.0 & 0.62 & 2.7 & 0.75 & 1.7 & 0.63 & 1.9 & 0.42 & 0.2 & 0.12 & 2.3 & 2.33 & 0.9 & 0.14 & 80 \\
\hline greater short-horned lizard & & & & & & & & & & & & & & & & 5 \\
\hline Chihuahuan spotted whiptail & 73 & $<0.1$ & 0.03 & 0.1 & 0.05 & 0.8 & 0.41 & 0.3 & 0.15 & 4.3 & 0.91 & 0.3 & 0.26 & & & 22 \\
\hline Madrean alligator lizard & 2 & $<0.1$ & 0.03 & & & & & & & & & 0.2 & 0.20 & & & 5 \\
\hline ring-necked snake & & & & & & & & & & & & & & & & 2 \\
\hline striped whipsnake & 2 & & & 0.2 & 0.16 & & & & & & & & & & & 4 \\
\hline mountain patch-nosed snake & & & & & & & & & & & & & & & & 2 \\
\hline gopher snake & & & & & & & & & & & & & & & & 10 \\
\hline narrow-headed gartersnake & 1 & & & & & & & $<0.1$ & 0.04 & & & & & & & 14 \\
\hline western terrestrial gartersnake & 5 & & & & & 0.3 & 0.11 & 0.1 & 0.04 & & & & & & & 6 \\
\hline black-necked gartersnake & 10 & & & & & 0.1 & 0.09 & $<0.1$ & 0.04 & 0.2 & 0.12 & 0.3 & 0.11 & 0.4 & 0.23 & \\
\hline black-tailed rattlesnake & 2 & & & & & & & & & 0.1 & 0.08 & 0.2 & 0.20 & & & 12 \\
\hline Species richness & & 7 & & 6 & & 8 & & 9 & & 8 & & 8 & & 5 & & 18 \\
\hline Total no. detections & & 98 & & 57 & & 14 & & 26 & & 24 & & 49 & & 2 & & 340 \\
\hline
\end{tabular}


The Arizona toad was the most abundant and at least one individual of this species was observed during 19 surveys (when present, the number of individuals ranged from one to 57). Despite the same survey effort during both 2001 and 2002, we found no American bullfrogs in 2001, yet we found them on six of the 14 surveys in 2002.

\section{Voucher Specimens and Photographs}

We documented the presence of species in or near the monument with specimen (15 species) and photographic vouchers (16 species; Appendix H). We obtained specimen or photographic vouchers for all but two species (Sonoran mountain kingsnake [Appendix E] and ring-necked snake).

\section{Inventory Completeness}

Based on a review by Rosen (Appendix J), range maps, habitat descriptions by Degenhardt et al. (1996), and our species accumulation curve (Fig. 4.2), we believe that we found all of the common species and most of the species that are expected to occur at the monument. Species that we did not find, but which may be present in the monument or surrounding lands (based on range maps and habitat descriptions in Degenhardt et al. [1996]) fall into three categories: (1) species that are "probable" based on range and/or habitat associations, (2) species that may occur but which are typically found at lower or higher elevations or environments (e.g., deserts or spruce-fir forests,

Table 4.5. Number of observations $(\mathrm{N})$ and relative abundance (mean \pm SE) of herpetofauna detected during road transect surveys, Gila Cliff Dwellings NM, 2001 and 2002. See Table 4.1 for summary of effort.

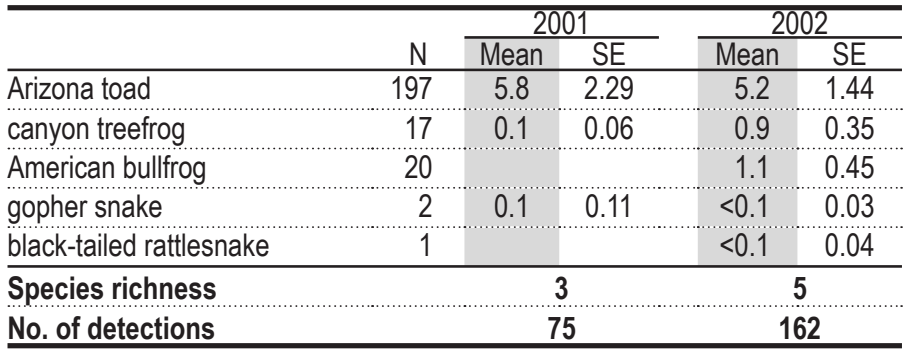

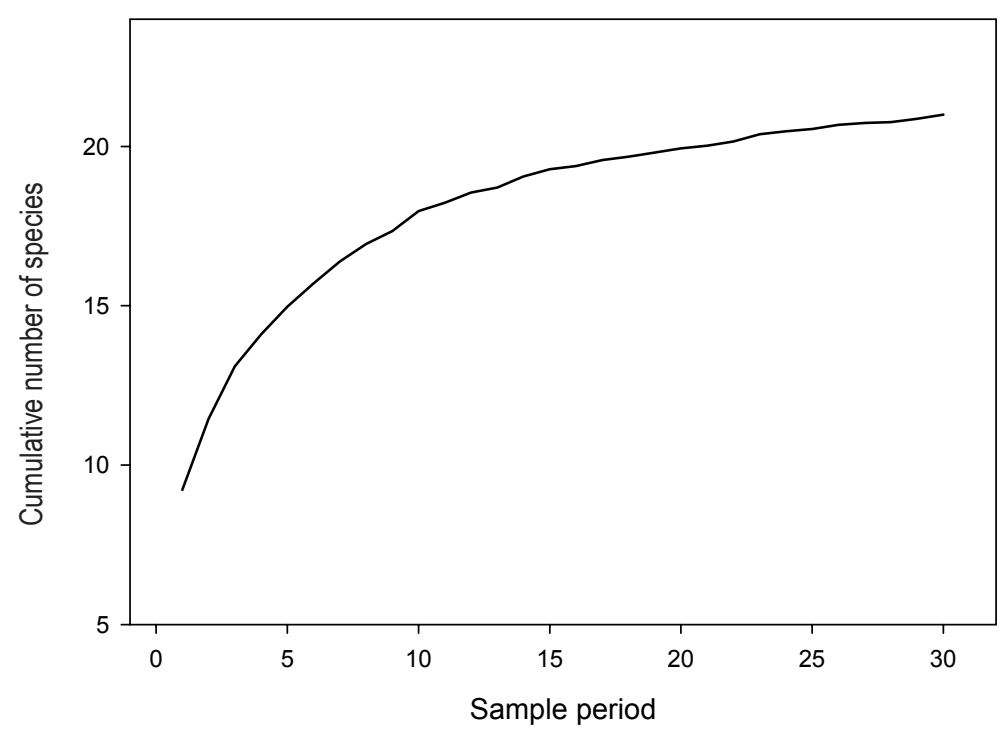

Figure 4.2 Species accumulation curves for intensive and extensive amphibian and reptile surveys, Gila Cliff Dwellings NM, 2001 and 2002. 
respectively), and (3) likely extirpated species (Appendix E; see also Discussion section below).

We believe there are five species that are likely to occur in the monument or surrounding lands that we did not find. Tiger salamander needs pools of water to breed, so habitat seems abundant, particularly along the West and Middle forks of the Gila River. The Museum of Southwestern Biology has a specimen obtained approximately 20 $\mathrm{km}$ from the monument, and Hayward and Hunt (1972) report that they found the salamander in "almost every stock tank in the [Gila] wilderness." Red-spotted toads are likely in rock outcrops in areas along the West and Middle forks, and Hayward and Hunt (1972) report that they were "common" near the visitor center. There appears to be an abundance of habitat for Sonoran mud turtles, particularly along the Middle Fork of the Gila River where there are large pools of water created by the American beaver. Although we searched for mud turtles, we did not use turtle traps, and therefore may have missed this species. Hayward and Hunt (1972) report that they photographed an individual not far from the monument in 1971. Many-lined skinks are probably rare but likely to be found along the West and Middle forks. Checkered gartersnake, like the black-necked gartersnake, is not restricted to the aquatic environment and may be found in any area of the monument. The western rattlesnake is possible in rocky outcrops and dry stream beds, particularly on the mesa and dry canyons to the west of the cliff dwellings.

A number of additional species that are "possible" include species that typically live in high elevation and rockier environments (mountain treefrog, western chorus frog, and rock rattlesnake) and some typically associated with lower elevation (broad valley) environments (spiny softshell turtle, desert spiny lizard, desert grassland whiptail, and night snake).

\section{Discussion}

As with the other taxonomic groups, this effort is the first comprehensive inventory of the area. Although search effort was not uniform among community types/area, we nevertheless were meticulous in maintaining records of our search effort, which allows us to draw conclusions about the relative abundance of species in the monument and surrounding lands.

Overall, the herpetofauna community at Gila Cliff Dwellings NM is relatively diverse for an area of its size, elevation, and geographic location. The wide variety of environmental conditions (e.g., soil types, topography, and vegetation) are reflected in the herpetofauna community. In particular, the lush canyon bottoms of the West and Middle forks of the Gila River contained a number of species not found in other community types/areas, particularly the narrowheaded and western terrestrial gartersnakes (Table 4.4). The narrow-headed gartersnake, in particular, is highly aquatic and is thought to be undergoing population declines in other areas (Phil Rosen, Appendix J). Fernandez and Rosen (1996) believed these declines were because of predation by non-native crayfish (Orconectes spp.), which have been reported from the Middle Fork but not from the West Fork of the Gila River (David Propst, pers. comm.).

Two of the three amphibian species that we documented, Arizona toad and American bullfrog, were the most abundant species in these mesic areas, and based on their high relative abundance in all survey types (except time-andarea constrained searches), they were the most abundant members of the community (Tables 4.2-4.4). The American bullfrog was very abundant along the West and Middle forks of the Gila River (Tables 4.2-4.4) where there appeared to be ample habitat for adults and tadpoles. The American bullfrog was exceptionally abundant in side channels with slow-moving water in both areas. The areas around and downstream of the hotspring along the Middle Fork, in particular, were teeming with American bullfrog tadpoles. (Observers noted the presence of tadpoles, and in some cases attempted to quantify them (e.g., " $1,000 \mathrm{~s}$ ") but our surveys were not well designed to count tadpoles). The American bullfrog is native to eastern North America but have been introduced throughout the western U.S. for food production and sport (Stebbins 2003). Bullfrogs are a species of management concern at the monument because bullfrog adults and tadpoles are voracious predators (Kiesecker and Blaustein 1997) and competitors (Kupferberg 1997) and are thought to be partially responsible for the decline 
of some native fish (Minckley and Deacon 1991), and many reptiles (Schwalbe and Rosen 1988), and amphibians (particularly other Ranid frogs; Hayes and Jennings 1986, Lawler et al. 1999) in the Southwest. Hayward and Hunt (1972) note that American bullfrogs were "common" in the area around the visitor center in 1971. We noted American bullfrog adults during road surveys in 2002 only; they are known to travel great distances in search of food or breeding habitat (Dennis Suhre, unpublished data).

Despite a concerted effort to find Chiricahua leopard frogs along the Middle and West forks of the Gila River, we found none. Historically, the Chiricahua leopard frog was found in and adjacent to the monument (Appendix J) where they were probably common. Their apparent absence from the area is troubling and may have been caused by the abundance of American bullfrogs. Other explanations for the extirpation of Chiricahua leopard frog may include (1) habitat alteration, (2) drought, (3) increases in ultraviolet radiation, and (4) chytrid fungus (Sredl et al. 2000), (5) non-native fishes, and (5) introduced crayfish. Among these other possible explanations, only chytrid fungus seems plausible here, although with a warm spring present, even this seems unlikely (Phil Rosen, pers. comm.). Indeed, the widespread occurrence and abundance of the American bullfrog point to it as the key cause of decline - or at least of final extirpation - for the Chiricahua leopard frog in the area around Gila Cliff Dwellings NM.

There are three other species of amphibians that Hayward and Hunt (1972) reported as being "common" in 1971 near the visitor center: Mexican spadefoot, Woodhouse's toad, and red-spotted toad. Of these, we could only find a voucher specimen for Woodhouse's toad (Appendix I). It is possible that we missed red-spotted toads in the rocky outcrops near the West and Middle forks of the Gila River, but it should have appeared along the river or other canyon bottoms. However, the two other species, Mexican spadefoot and Woodhouse's toad, should have been recorded during one of our 28 road surveys. The absence of these species is cause for concern (see Chapter 7), although there is no independent confirmation or voucher for the Hayward and Hunt (1972) records for the redspotted toad and Mexican spadefoot. While these species may all be part of a general amphibian decline, that conclusion would be premature, and probably could only be evaluated with a broader survey, of the West and Middle Forks of Gila River.

The certain extirpation of the Chiricahua leopard frog and possible extirpation of three other species of amphibian indicate an aquatic system that is in serious trouble. Some reptiles may be on their way out as well, including narrow-headed and black-necked gartersnakes (Don Swann, pers. comm.). Given the large populations of non-native fishes, American bullfrogs, and crayfish, it is likely that these species will continue to have devastating impacts on the native herpetofauna community (see Chapter 7 for more information).

Arizona toads are thought to be highly sensitive to habitat alteration, and unlike most Bufo species in New Mexico, they are generally not found in agricultural areas (Degenhardt et al. 1996). They require permanent water and do not need monsoon rains to initiate breeding, which would explain why we saw them throughout both summers. The abundance of the Arizona toad in the presence of a large American bullfrog population may be explained by the fact that the toads have toxins in their skins, which could make them inedible to bullfrogs (Degenhardt et al. 1996).

An unexpected herpetological observation of our study was a single western box turtle, which was found approximately $5 \mathrm{~km}$ from the monument. No other specimens exist for the region, though Hayward and Hunt (1972) note that Bill Rogers, an amateur naturalist, saw them on two occasions near the monument. Phil Rosen (Appendix J) considers the individual that we found to be "questionable or peripheral" because the individual may have been translocated as a captive. He suggests that confirmation of additional individuals (especially young) would clarify their status in the area. 


\section{Chapter 5: Bird Inventory}

\section{Previous Research}

To our knowledge there have been no comprehensive bird surveys at the monument or surrounding area. Joan Day-Martin banded hummingbirds at the visitor center in 2001. Dale Zimmerman (1995) completed a checklist for the Gila National Forest, but he did not indicate how the list was created.

\section{Methods}

We surveyed for birds at the West unit in 2001 and 2002. We used three field methods: variable circular-plot counts for diurnal breeding-season birds, nocturnal surveys for owls and nightjars, and incidental observations for all birds. We concentrated our survey effort during the breeding season because bird distribution is relatively uniform due to territoriality among birds (Bibby et al. 2002). This survey timing increased our precision in estimating relative abundance and enabled us to document breeding activity. Our survey period included peak spring migration times for most species, which added many migratory species to our list.

We sampled vegetation associated with diurnal survey stations. Vegetation structure and plant species composition are important predictors of bird species richness and the presence of particular species (MacArthur and MacArthur 1961, Rice et al. 1984, Strong and Bock 1990, Powell and Steidl 2000).

\section{Spatial Sampling Design and General Vegetation Characteristics}

We subjectively determined the location of all survey stations as a matter of convenience or logistical necessity. Because of its small size, we surveyed most areas of the monument and some of the surrounding Gila National Forest lands (Fig. $5.1)$.

We established two transects with six stations each: one along the West Fork of the Gila River ("Riparian") and another transect with three stations in Cliff Dweller Canyon and three stations on the ridge above the canyon ("Canyon"; Table
5.1; Fig. 5.1). The vegetation along the Riparian transect is dominated by narrowleaf cottonwood and willow along the West Fork of the Gila River (Table 5.1). Juniper and ponderosa pine dominate the adjacent slopes. Stations in the cool, moist Cliff Dweller Canyon (Canyon transect stations 4-6) are dominated by juniper, Gambel oak, and narrowleaf cottonwood with many herbaceous plants in the canyon bottom. Stations on the ridge above Cliff Dweller Canyon (Canyon transect stations 1-3) were more xeric and had pine and juniper with little understory vegetation.

\section{VCP Surveys}

\section{Field Methods}

We used the variable circular-plot method (VCP) to survey for diurnally active birds during the breeding season (Reynolds et al. 1980, Buckland et al. 2001). Conceptually, these surveys are similar to traditional "point counts" (Ralph et. al 1995) during which an observer spends a standardized length of time at one location and records all birds seen or heard and the distance to each bird or group of birds.

Stations along each transect were a minimum of $250 \mathrm{~m}$ apart to help maintain independence among observations at each station. Each year we surveyed from April through July, the period of peak breeding activity. The number of annual visits to each station varied slightly in some cases, but we maintained a minimum of 10 days between surveys. On each visit we alternated observers and the order in which we surveyed stations to minimize bias by observer, time of day, and direction of travel. We began bird surveys approximately 30 minutes before sunrise and concluded no later than four hours after sunrise, or when bird activity decreased markedly. We did not survey when winds exceeded $15 \mathrm{~km} / \mathrm{h}$ or when precipitation exceeded an intermittent drizzle.

We recorded a number of environmental variables prior to beginning each transect: wind speed category (Beaufort scale), presence and severity of rain (qualitative assessment), air temperature $\left({ }^{\circ} \mathrm{F}\right)$, relative humidity $(\%)$, and cloud cover (\%). After arriving at a station, we 

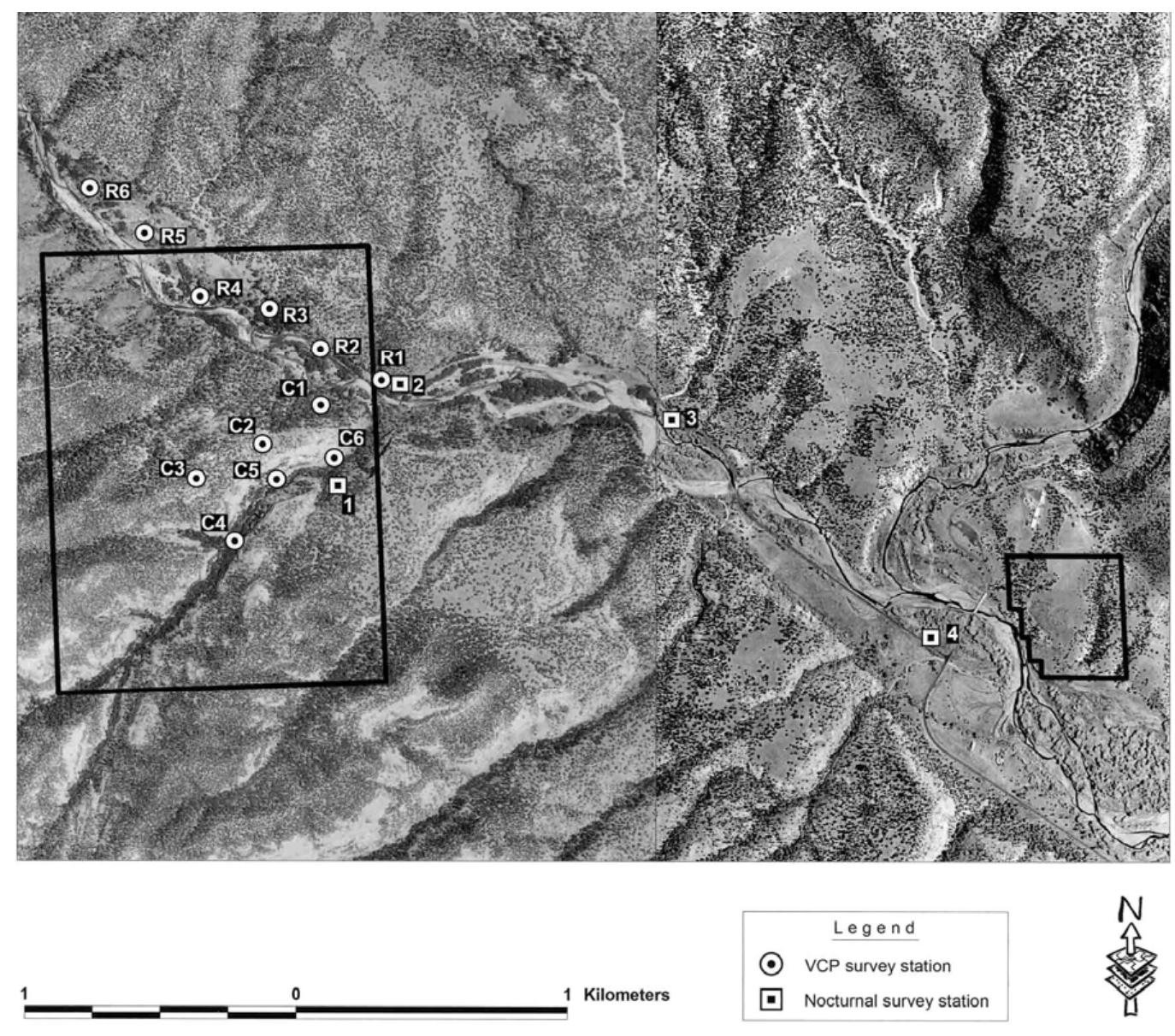

Figure 5.1. Location of bird survey stations, Gila Cliff Dwellings NM, 2001 and 2002. "C" = Canyon transect, "R" = Riparian transect.

waited for one minute before beginning the count to allow birds to resume their normal activities. We identified (to species) all birds seen or heard during an eight-minute "active" period. For each detection, we recorded its distance in meters from the observer (measured with laser range finder when possible), time of detection (measured in one-minute intervals beginning at the start of the active period), and the sex and/or age class (adult or juvenile) if known. We did not measure distances to birds that were seen flying overhead, nor did we use techniques to attract birds (e.g., "pishing"). We made an effort to avoid doublecounting individuals that had been recorded at previous stations. If we observed a species during the "passive" count period (between the eight-minute counts) that had not been recorded previously at a station on that visit, we recorded its distance to the nearest station.

\section{Effort}

We surveyed each of the six stations of the Riparian transect five times in both 2001 and 2002, and each of the six stations of the Canyon transect four times in 2001. In 2002 we surveyed most stations (numbers 1-4) of the Canyon transect five times, but surveyed two stations (numbers 5 and 6) four times because of problems with gaining access to Cliff Dweller Canyon.

\section{Analyses}

We calculated relative abundance of each species (on each transect) as the number of detections at all stations and visits divided by sample size (number of visits multiplied by number stations). To estimate our mean and standard error, we included visits to stations for which we did not detect birds. We reduced our full collection of observations $(\mathrm{N}$ 


\begin{tabular}{|c|c|c|c|c|c|c|c|c|}
\hline Transect & Station & $\begin{array}{l}\text { juniper } \\
\text { species }^{\mathrm{a}}\end{array}$ & $\begin{array}{l}\text { Two-needle } \\
\text { pinyon pine }\end{array}$ & $\begin{array}{l}\text { Ponderosa } \\
\text { pine }\end{array}$ & $\begin{array}{l}\text { narrowleaf } \\
\text { cottonwood }\end{array}$ & $\begin{array}{l}\text { Gambel } \\
\text { oak }\end{array}$ & gray oak & $\begin{array}{l}\text { willow } \\
\text { species }\end{array}$ \\
\hline \multirow[t]{6}{*}{ Riparian } & 1 & 5.4 & & 2.5 & 14.9 & & 0.4 & 18.7 \\
\hline & 2 & 64.3 & 41.8 & 25.5 & 43.8 & & 64.3 & 418.5 \\
\hline & 3 & 28.0 & & 7.8 & 114.2 & & & \\
\hline & 4 & 0.5 & & 0.7 & 181.6 & & & 120.2 \\
\hline & 5 & 0.2 & & 1.6 & 8.5 & & & 3.2 \\
\hline & 6 & 31.4 & & 1.1 & 45.3 & \multirow{4}{*}{11.7} & & 23.2 \\
\hline \multirow{6}{*}{ Canyon } & 1 & 77.0 & 19.2 & 174.3 & & & & \\
\hline & 2 & 52.0 & 11.0 & 11.8 & & & 0.7 & \\
\hline & 3 & 91.3 & 60.6 & 0.3 & & & 0.3 & \\
\hline & 4 & 100.3 & & & & 65.4 & 19.0 & \\
\hline & 5 & 38.5 & 13.4 & 8.1 & 30.1 & 15.0 & 34.4 & \\
\hline & 6 & 2.7 & 5.8 & 2.7 & 11.4 & 16.9 & & \\
\hline
\end{tabular}

a alligator, Utah, and Rocky Mountain juniper.

$=1,333)$ to a subset of data $(n=551 ; 380$ for the Riparian transect and 171 for the Canyon transect) that was more appropriate for estimating relative abundance. First, we used only those detections that occurred $\leq 75 \mathrm{~m}$ from count stations ( $n=469$ observations) because detectability is influenced by conspicuousness of birds (i.e., loud, large, or colorful species are more detectable than others) and environmental conditions (dense vegetation can reduce likelihood of some detections); truncating detections may reduce the influence of these factors (Verner and Ritter 1983; for a review of factors influencing detectability, see Farnsworth et al. 2002). We also excluded birds that were observed flying over the station (174 observations), birds observed outside of the eight-minute count period (231 observations), and unknown species (23 observations). Some observations met more than one of these criteria for exclusion from analysis.

\section{Nocturnal Surveys}

\section{Field Methods}

To survey for owls we broadcasted commercially available vocalizations (Colver et al. 1999) using a compact disc player and broadcaster (Bibby et al. 2002), and we recorded other nocturnal species (nighthawks and poorwills) when observed. We established one nocturnal transect (four stations) along the access road and into Cliff Dweller
Canyon (Fig. 5.1). Stations were a minimum of $300 \mathrm{~m}$ apart. As with other survey methods, we varied observers and direction of travel along transects and did not survey during periods of excessive rain or wind. We began surveys at approximately 45 minutes after sunset.

We began surveys at each station with a three-minute "passive" listening period during which time we broadcast no calls. We then broadcasted vocalizations for a series of twominute "active" periods. We used vocalizations of owl species we thought might be present, based on habitat requirements and range: elf, northern pygmy, flamulated, western screech, barn, and long-eared. We broadcast recordings of owls in sequence from smallest to largest size species so that smaller species would not be inhibited by the "presence" of larger predators or competitors (Fuller and Mosher 1987). During active periods, we broadcast owl vocalizations for 30 seconds followed by a 30 -second listening period. This pattern was repeated two times for each species. We excluded great horned owl from the broadcast sequence because of its aggressive behavior toward other owls. We did not survey for the federally threatened Mexican spotted owl because that would have required a specific protocol. During the count period we used a flashlight to scan nearby vegetation for visual detections. If we observed a bird during the three-minute passive period, we recorded the minute of the passive 
period in which the bird was first observed, the type of detection (aural, visual, or both), and the distance to the bird. If we observed a bird during the two-minute active periods, we recorded in which interval(s) it was detected and the type of detection (aural, visual, or both). As with other survey types, we attempted to avoid doublecounting individuals recorded at previous stations. We also used multiple observers, alternated direction of travel, and did not survey during inclement weather.

\section{Effort}

We established one transect of four stations and visited each station four times in 2001 and five times in 2002.

\section{Analysis}

We report the total number of detections because sample size was inadequate for developing meaningful estimates of relative abundance.

\section{Incidental and Breeding Observations}

\section{Field Methods}

When we were not conducting formal surveys and encountered a rare species, a species in an unusual location, or an individual engaged in a breeding behavior, we recorded UTM coordinates, time of detection, and (if known) the sex and age class of the bird. We recorded all breeding behavior observations using the standardized classification system (developed by the North American Ornithological Atlas Committee; NAOAC 1990). This system classifies breeding behavior into one of nine categories: adult carrying nesting material, nest building, adult performing distraction display, used nest, fledged young, occupied nest, adult carrying food, adult feeding young, or adult carrying a fecal sac. We made breeding observations during both standardized surveys and incidental observations.

\section{Analysis}

We report frequency counts of incidental and breeding observations; we cannot calculate relative abundance (as for VCP surveys) because we did not standardize survey effort.

\section{Vegetation Sampling at Diurnal VCP Stations}

We sampled vegetation near each VCP survey station to characterize community composition and structure. These data could be used to help determine habitat associations for bird species and identify important features of species-rich communities at the monument. We sampled vegetation at five plots located at a modifiedrandom direction and distance from each station. Each plot was located within a $72^{\circ}$ range of the compass from the station (e.g., Plot 3 was located from $145^{\circ}$ to $216^{\circ}$ ) to reduce clustering of plots. We randomly placed plots from 0 to $75 \mathrm{~m}$ from each station to correspond with truncation of bird data used in estimating relative abundance.

At each plot we used the point-quarter method (Krebs 1998) to sample vegetation by dividing the plot into four quadrants along cardinal directions. We applied this method to plants in four size categories: sub-shrubs $(0.5-1.0 \mathrm{~m})$, shrubs $(>1.0-2.0 \mathrm{~m})$, trees $(>2.0 \mathrm{~m})$, and potential cavity-bearing vegetation $(>20 \mathrm{~cm}$ diameter at breast height). If there was no vegetation in a given category within $25 \mathrm{~m}$ of the plot center, we indicated this in the species column. For each individual plant we recorded distance from the plot center, species, height, and maximum canopy diameter (excluding errant branches). Association of a plant to a quadrant was determined by the location of its trunk, regardless of which quadrant contained the majority of the plant; no plant was recorded in $>1$ quadrant. Standing dead vegetation was only attributed to the "potential cavity-bearing tree" category. On rare occasions when plots overlapped we repeated the selection process for the second plot.

Within a 5-m radius around the center of each plot, we visually estimated (1) percent ground cover by type (bare ground, litter, or rock [loose rocks or stones]) and (2) percent aerial cover of vegetation in each quadrant using three height categories: $0-0.5 \mathrm{~m},>0.5-2 \mathrm{~m}$, and > $2 \mathrm{~m}$.

\section{Analysis}

Using point-quarter data, we calculated mean density (number of stems/ha) for all species in 
each of the four height/size categories using the computer program "Krebs" (Krebs 1998). We collected these data to quantify vegetation characteristics around survey stations. The detailed results of these surveys will be archived in the same locations as indicated in Chapter 1.

\section{Results}

We observed 107 species, all but three of which (peregrine falcon, yellow-headed blackbird, and indigo bunting) were observed inside the monument boundary (Appendix C). We found no non-native species and observed only one species of high conservation concern: peregrine falcon, listed as a "species of conservation concern" by the U.S. Fish and Wildlife Service. Five other species, including the common black hawk and Bell's vireo, have additional conservation designations (see Appendix C).

\section{VCP Surveys}

We recorded 91 species during VCP surveys in 2001 and 2002. From these we were able to calculate relative abundance for 62 species (Tables 5.2, 5.3). After excluding birds observed $>75 \mathrm{~m}$ from stations and birds seen flying over stations, we found 50 species on the Riparian transect and 39 on the Canyon transect. Among these species, we observed 23 at the Riparian transect that we did not observe at the Canyon transect, and 12 species at the Canyon transect not observed at the Riparian transect (Tables 5.2, 5.3). Abundance ranks among species that we found on both transects changed markedly. In order of abundance, from first to third most abundant species for the Canyon transect were the painted redstart, spotted towhee, and cordilleran flycatcher, but for the Riparian transect the three most abundant were the spotted towhee, house wren, and American robin.

We observed 36 species that were consistent members of the breeding-season bird community at Gila Cliff Dwellings NM (at least one individual present during at least five of the six two-week periods from 1 May to 31 July, both years; Appendix K). Other species were either less common or migratory (e.g., many warbler species).

There were marked intra-transect differences in the number of individuals recorded at each point in each transect. Along the Riparian transect, we observed 16 species at only one station and in only one year whereas we observed 14 species at $\geq 75 \%$ of the stations in both years. Along the Canyon transect we observed 20 species at only one station and in only one year, whereas eight species were found at $\geq 75 \%$ of the stations in both years. The violet green swallow was the only species observed at least once at all stations in both transects in 2001 and 2002.

\section{Nocturnal Surveys}

Despite consistent effort throughout the two years of the study, we recorded only five observations of four species of nocturnal birds: one observation each of the western screech owl, great horned owl, and common poorwill, and two observations of the common nighthawk (Appendix C).

\section{Incidental and Breeding Observations}

We observed 81 species during incidental observations including 13 species that were not recorded using the other two survey types (Appendix C). We made 66 observations, representing 31 species that confirmed breeding in or near the monument (Table 5.4). Breeding behavior was observed most often for the American robin.

\section{Inventory Completeness}

Based on the species accumulation curve (Fig. 5.2) and our knowledge of the bird community, we documented at least $90 \%$ of the species that bred on or immediately adjacent to the monument during the time of our study. We also base this assertion on the extensive nest searching and incidental observations reported by our field crews. Because our surveys were a snapshot-in-time of the bird community, there may be as many as 40 additional species that may breed at the monument (Appendix F) in any given year (based on a list compiled by Zimmerman [1995]). Many of those species, such as the Mexican jay and crissal thrasher, are associated with drier conditions; others such the sharp-shinned hawk, brown creeper, red-breasted nuthatch, and pine siskin would typically be found at higher elevations. The 
Table 5.2. Number of observations (sum) and relative abundance (mean \pm SE) of birds observed within $75 \mathrm{~m}$ of stations along the Riparian transect, Gila Cliff Dwellings NM, 2001 and 2002. See Methods section for details on estimation of relative abundance.

\begin{tabular}{|c|c|c|c|c|c|c|c|c|c|}
\hline \multirow[b]{3}{*}{ Species } & \multicolumn{9}{|c|}{ Year } \\
\hline & \multicolumn{3}{|c|}{$\begin{array}{c}2001 \\
(n=30)\end{array}$} & \multicolumn{3}{|c|}{$\begin{array}{c}2002 \\
(n=30)\end{array}$} & \multicolumn{3}{|c|}{$\begin{array}{c}2001 \text { and } 2002 \\
(n=60)\end{array}$} \\
\hline & Sum & Mean & SE & Sum & Mean & SE & Sum & Mean & SE \\
\hline great blue heron & 1 & 0.03 & 0.033 & & & & 1 & 0.02 & 0.017 \\
\hline turkey vulture & & & & 1 & 0.03 & 0.033 & 1 & 0.02 & 0.017 \\
\hline American kestrel & 3 & 0.10 & 0.100 & & & & 3 & 0.05 & 0.050 \\
\hline mourning dove & 6 & 0.20 & 0.101 & 12 & 0.40 & 0.113 & 18 & 0.30 & 0.076 \\
\hline black-chinned hummingbird & 1 & 0.03 & 0.033 & 1 & 0.03 & 0.033 & 2 & 0.03 & 0.023 \\
\hline broad-tailed hummingbird & 2 & 0.07 & 0.046 & 1 & 0.03 & 0.033 & 3 & 0.05 & 0.028 \\
\hline rufous hummingbird & 1 & 0.03 & 0.033 & & & & 1 & 0.02 & 0.017 \\
\hline acorn woodpecker & 4 & 0.13 & 0.079 & 4 & 0.13 & 0.063 & 8 & 0.13 & 0.050 \\
\hline hairy woodpecker & & & & 1 & 0.03 & 0.033 & 1 & 0.02 & 0.017 \\
\hline northern flicker & 2 & 0.07 & 0.067 & 8 & 0.27 & 0.095 & 10 & 0.17 & 0.059 \\
\hline western wood-pewee & 1 & 0.03 & 0.033 & 4 & 0.13 & 0.063 & 5 & 0.08 & 0.036 \\
\hline cordilleran flycatcher & 1 & 0.03 & 0.033 & & & & 1 & 0.02 & 0.017 \\
\hline black phoebe & 1 & 0.03 & 0.033 & 1 & 0.03 & 0.033 & 2 & 0.03 & 0.023 \\
\hline ash-throated flycatcher & 4 & 0.13 & 0.079 & 1 & 0.03 & 0.033 & 5 & 0.08 & 0.043 \\
\hline Cassin's kingbird & 1 & 0.03 & 0.033 & & & & 1 & 0.02 & 0.017 \\
\hline plumbeous vireo & 3 & 0.10 & 0.056 & 3 & 0.10 & 0.074 & 6 & 0.10 & 0.046 \\
\hline warbling vireo & 11 & 0.37 & 0.140 & 11 & 0.37 & 0.112 & 22 & 0.37 & 0.089 \\
\hline Steller's jay & 2 & 0.07 & 0.046 & 4 & 0.13 & 0.079 & 6 & 0.10 & 0.046 \\
\hline Lincoln's sparrow & & & & 2 & 0.07 & 0.046 & 2 & 0.03 & 0.023 \\
\hline western scrub-jay & 1 & 0.03 & 0.033 & 2 & 0.07 & 0.046 & 3 & 0.05 & 0.028 \\
\hline purple martin & 11 & 0.37 & 0.200 & 17 & 0.57 & 0.321 & 28 & 0.47 & 0.188 \\
\hline violet-green swallow & 3 & 0.10 & 0.100 & 19 & 0.63 & 0.367 & 22 & 0.37 & 0.192 \\
\hline bridled titmouse & & & & 3 & 0.10 & 0.100 & 3 & 0.05 & 0.050 \\
\hline bushtit & 3 & 0.10 & 0.074 & 4 & 0.13 & 0.133 & 7 & 0.12 & 0.076 \\
\hline white-breasted nuthatch & 1 & 0.03 & 0.033 & & & & 1 & 0.02 & 0.017 \\
\hline pygmy nuthatch & & & & 6 & 0.20 & 0.200 & 6 & 0.10 & 0.100 \\
\hline Bewick's wren & 1 & 0.03 & 0.033 & 1 & 0.03 & 0.033 & 2 & 0.03 & 0.023 \\
\hline house wren & 29 & 0.97 & 0.217 & 23 & 0.77 & 0.141 & 52 & 0.87 & 0.129 \\
\hline blue-gray gnatcatcher & 1 & 0.03 & 0.033 & & & & 1 & 0.02 & 0.017 \\
\hline Townsend's solitaire & & & & 1 & 0.03 & 0.033 & 1 & 0.02 & 0.017 \\
\hline American robin & 12 & 0.40 & 0.113 & 16 & 0.53 & 0.171 & 28 & 0.47 & 0.102 \\
\hline gray catbird & & & & 1 & 0.03 & 0.033 & 1 & 0.02 & 0.017 \\
\hline Virginia's warbler & 3 & 0.10 & 0.056 & 11 & 0.37 & 0.102 & 14 & 0.23 & 0.060 \\
\hline yellow warbler & 2 & 0.07 & 0.046 & 1 & 0.03 & 0.033 & 3 & 0.05 & 0.028 \\
\hline Wilson's warbler & & & & 1 & 0.03 & 0.033 & 1 & 0.02 & 0.017 \\
\hline painted redstart & 2 & 0.07 & 0.046 & 3 & 0.10 & 0.056 & 5 & 0.08 & 0.036 \\
\hline yellow-breasted chat & 8 & 0.27 & 0.082 & 11 & 0.37 & 0.089 & 19 & 0.32 & 0.061 \\
\hline hepatic tanager & 2 & 0.07 & 0.067 & 1 & 0.03 & 0.033 & 3 & 0.05 & 0.037 \\
\hline western tanager & 1 & 0.03 & 0.033 & 4 & 0.13 & 0.063 & 5 & 0.08 & 0.036 \\
\hline green-tailed towhee & & & & 2 & 0.07 & 0.046 & 2 & 0.03 & 0.023 \\
\hline spotted towhee & 37 & 1.23 & 0.171 & 38 & 1.27 & 0.135 & 75 & 1.25 & 0.108 \\
\hline canyon towhee & 6 & 0.20 & 0.121 & & & & 6 & 0.10 & 0.062 \\
\hline white-crowned sparrow & & & & 2 & 0.07 & 0.067 & 2 & 0.03 & 0.033 \\
\hline dark-eyed junco & 2 & 0.07 & 0.046 & & & & 2 & 0.03 & 0.023 \\
\hline black-headed grosbeak & 6 & 0.20 & 0.088 & 16 & 0.53 & 0.142 & 22 & 0.37 & 0.086 \\
\hline blue grosbeak & 10 & 0.33 & 0.121 & 1 & 0.03 & 0.033 & 11 & 0.18 & 0.065 \\
\hline Brewer's blackbird & 3 & 0.10 & 0.074 & 6 & 0.20 & 0.088 & 9 & 0.15 & 0.057 \\
\hline brown-headed cowbird & 2 & 0.07 & 0.046 & 3 & 0.10 & 0.056 & 5 & 0.08 & 0.036 \\
\hline Bullock's oriole & & & & 4 & 0.13 & 0.104 & 4 & 0.07 & 0.052 \\
\hline lesser goldfinch & 3 & 0.10 & 0.074 & & & & 3 & 0.05 & 0.037 \\
\hline
\end{tabular}


Table 5.3. Number of observations (sum) and relative abundance (mean $\pm \mathrm{SE}$ ) of birds observed within $75 \mathrm{~m}$ of stations along the Canyon transect, Gila Cliff Dwellings NM, 2001 and 2002. See Methods section for details on estimation of relative abundance.

\begin{tabular}{|c|c|c|c|c|c|c|c|c|c|}
\hline \multirow[b]{3}{*}{ Species } & \multicolumn{9}{|c|}{ Year } \\
\hline & \multicolumn{3}{|c|}{$2001(n=24)$} & \multicolumn{3}{|c|}{$2002(n=28)$} & \multicolumn{3}{|c|}{$\begin{array}{c}2001 \text { and } 2002 \\
(n=52)\end{array}$} \\
\hline & Sum & Mean & SE & Sum & Mean & SE & Sum & Mean & SE \\
\hline mourning dove & 3 & 0.13 & 0.092 & 6 & 0.21 & 0.079 & 9 & 0.17 & 0.060 \\
\hline northern pygmy-owl & 1 & 0.04 & 0.042 & & & & 1 & 0.02 & 0.019 \\
\hline black-chinned hummingbird & & & & 1 & 0.04 & 0.036 & 1 & 0.02 & 0.019 \\
\hline broad-tailed hummingbird & 1 & 0.04 & 0.042 & 1 & 0.04 & 0.036 & 2 & 0.04 & 0.027 \\
\hline acorn woodpecker & 3 & 0.13 & 0.125 & & & & 3 & 0.06 & 0.058 \\
\hline hairy woodpecker & & & & 2 & 0.07 & 0.050 & 2 & 0.04 & 0.027 \\
\hline northern flicker & 1 & 0.04 & 0.042 & & & & 1 & 0.02 & 0.019 \\
\hline western wood-pewee & & & & 1 & 0.04 & 0.036 & 1 & 0.02 & 0.019 \\
\hline gray flycatcher & 1 & 0.04 & 0.042 & & & & 1 & 0.02 & 0.019 \\
\hline cordilleran flycatcher & 7 & 0.29 & 0.127 & 6 & 0.21 & 0.094 & 13 & 0.25 & 0.077 \\
\hline ash-throated flycatcher & 2 & 0.08 & 0.058 & 3 & 0.11 & 0.079 & 5 & 0.10 & 0.050 \\
\hline plumbeous vireo & 2 & 0.08 & 0.058 & 6 & 0.21 & 0.094 & 8 & 0.15 & 0.058 \\
\hline warbling vireo & 2 & 0.08 & 0.058 & 1 & 0.04 & 0.036 & 3 & 0.06 & 0.033 \\
\hline Steller's jay & 3 & 0.13 & 0.069 & 2 & 0.07 & 0.050 & 5 & 0.10 & 0.041 \\
\hline western scrub-jay & & & & 1 & 0.04 & 0.036 & 1 & 0.02 & 0.019 \\
\hline common raven & 1 & 0.04 & 0.042 & 2 & 0.07 & 0.050 & 3 & 0.06 & 0.033 \\
\hline violet-green swallow & & & & 1 & 0.04 & 0.036 & 1 & 0.02 & 0.019 \\
\hline mountain chickadee & 1 & 0.04 & 0.042 & 1 & 0.04 & 0.036 & 2 & 0.04 & 0.027 \\
\hline bushtit & 5 & 0.21 & 0.134 & 6 & 0.21 & 0.130 & 11 & 0.21 & 0.092 \\
\hline white-breasted nuthatch & & & & 1 & 0.04 & 0.036 & 1 & 0.02 & 0.019 \\
\hline pygmy nuthatch & & & & 4 & 0.14 & 0.143 & 4 & 0.08 & 0.077 \\
\hline rock wren & & & & 2 & 0.07 & 0.050 & 2 & 0.04 & 0.027 \\
\hline canyon wren & 2 & 0.08 & 0.058 & 4 & 0.14 & 0.067 & 6 & 0.12 & 0.045 \\
\hline Bewick's wren & 1 & 0.04 & 0.042 & 1 & 0.04 & 0.036 & 2 & 0.04 & 0.027 \\
\hline house wren & 1 & 0.04 & 0.042 & 1 & 0.04 & 0.036 & 2 & 0.04 & 0.027 \\
\hline blue-gray gnatcatcher & 1 & 0.04 & 0.042 & 1 & 0.04 & 0.036 & 2 & 0.04 & 0.027 \\
\hline American robin & 5 & 0.21 & 0.085 & 5 & 0.18 & 0.074 & 10 & 0.19 & 0.055 \\
\hline olive warbler & & & & 1 & 0.04 & 0.036 & 1 & 0.02 & 0.019 \\
\hline Virginia's warbler & & & & 1 & 0.04 & 0.036 & 1 & 0.02 & 0.019 \\
\hline yellow-rumped warbler & & & & 1 & 0.04 & 0.036 & 1 & 0.02 & 0.019 \\
\hline black-throated gray warbler & 4 & 0.17 & 0.078 & 2 & 0.07 & 0.050 & 6 & 0.12 & 0.045 \\
\hline Townsend's warbler & 1 & 0.04 & 0.042 & & & & 1 & 0.02 & 0.019 \\
\hline Grace's warbler & & & & 1 & 0.04 & 0.036 & 1 & 0.02 & 0.019 \\
\hline red-faced warbler & 4 & 0.17 & 0.078 & 1 & 0.04 & 0.036 & 5 & 0.10 & 0.041 \\
\hline painted redstart & 10 & 0.42 & 0.158 & 13 & 0.46 & 0.109 & 23 & 0.44 & 0.093 \\
\hline western tanager & 5 & 0.21 & 0.085 & 5 & 0.18 & 0.090 & 10 & 0.19 & 0.062 \\
\hline spotted towhee & 9 & 0.38 & 0.145 & 11 & 0.39 & 0.130 & 20 & 0.38 & 0.096 \\
\hline black-headed grosbeak & 5 & 0.21 & 0.085 & 3 & 0.11 & 0.060 & 8 & 0.15 & 0.051 \\
\hline brown-headed cowbird & & & & 1 & 0.04 & 0.036 & 1 & 0.02 & 0.019 \\
\hline
\end{tabular}


Table 5.4. Number of breeding-behavior observations for birds, Gila Cliff Dwellings NM, 2001 and 2002. Breeding behaviors follow NAOAC (1990).

\begin{tabular}{|c|c|c|c|c|c|c|c|c|c|c|}
\hline Species & $\begin{array}{c}\text { Nest } \\
\text { building }\end{array}$ & $\begin{array}{l}\text { Nest } \\
\text { with } \\
\text { eggs }\end{array}$ & $\begin{array}{l}\text { Nest with } \\
\text { young }\end{array}$ & $\begin{array}{c}\text { Occupied } \\
\text { nest }\end{array}$ & $\begin{array}{l}\text { Adults } \\
\text { carrying } \\
\text { food }\end{array}$ & $\begin{array}{c}\text { Adults } \\
\text { carrying } \\
\text { nesting } \\
\text { material }\end{array}$ & $\begin{array}{c}\text { Used } \\
\text { nest or } \\
\text { eggshells }\end{array}$ & $\begin{array}{c}\text { Adults } \\
\text { feeding } \\
\text { recently } \\
\text { fledged } \\
\text { young }\end{array}$ & $\begin{array}{c}\text { Recently } \\
\text { fledged } \\
\text { young }\end{array}$ & Total \\
\hline great blue heron & & & & & & & 2 & & & 2 \\
\hline American kestrel & & & & & & & & & 1 & 1 \\
\hline mourning dove & & & & 1 & & & & & & 1 \\
\hline common nighthawk & & 2 & & & & & & & & 2 \\
\hline hairy woodpecker & & & & & 1 & & & & & 1 \\
\hline black phoebe & & & 1 & & & & 1 & 1 & & 3 \\
\hline Say's phoebe & & & & & & & & & 1 & 1 \\
\hline plumbeous vireo & & & & & 1 & & & & 1 & 2 \\
\hline warbling vireo & 1 & & & & & & & & & 1 \\
\hline pinyon jay & & & & & & & & & 1 & 1 \\
\hline purple martin & & & & 1 & & & & & 1 & 2 \\
\hline violet-green swallow & & & & 1 & & & 1 & & 1 & 3 \\
\hline northern rough-winged swallow & & & & 1 & & & & & & 1 \\
\hline cliff swallow & & & & 2 & & & 1 & & & 3 \\
\hline 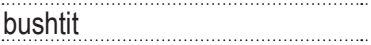 & & & & 2 & & & & & & 2 \\
\hline canyon wren & & 1 & & & & & & & 2 & 3 \\
\hline house wren & & & & & 1 & & & & 2 & 3 \\
\hline western bluebird & & & & & & & & & 1 & 1 \\
\hline American robin & 1 & & 1 & & 2 & & 2 & 2 & & 8 \\
\hline yellow warbler & & & & & 1 & & & 1 & & 2 \\
\hline black-throated gray warbler & & & & & & 2 & & & 1 & 3 \\
\hline painted redstart & & & 1 & & 2 & & & & 3 & 6 \\
\hline hepatic tanager & & & & & 1 & & & & & 1 \\
\hline western tanager & & & 1 & & & & & & & 1 \\
\hline chipping sparrow & & & & & & & & & 1 & 1 \\
\hline spotted towhee & & & & & 2 & & & & 2 & 4 \\
\hline canyon towhee & & & & & & & & & 2 & 2 \\
\hline black-headed grosbeak & & & & & & & & 1 & & 1 \\
\hline blue grosbeak & & & & & & & & & 1 & 1 \\
\hline Brewer's blackbird & & & & & & 2 & & & & 2 \\
\hline brown-headed cowbird & & & & & & & & & 1 & 1 \\
\hline Total & 2 & 3 & 4 & 8 & 11 & 4 & 7 & 5 & 21 & 66 \\
\hline
\end{tabular}

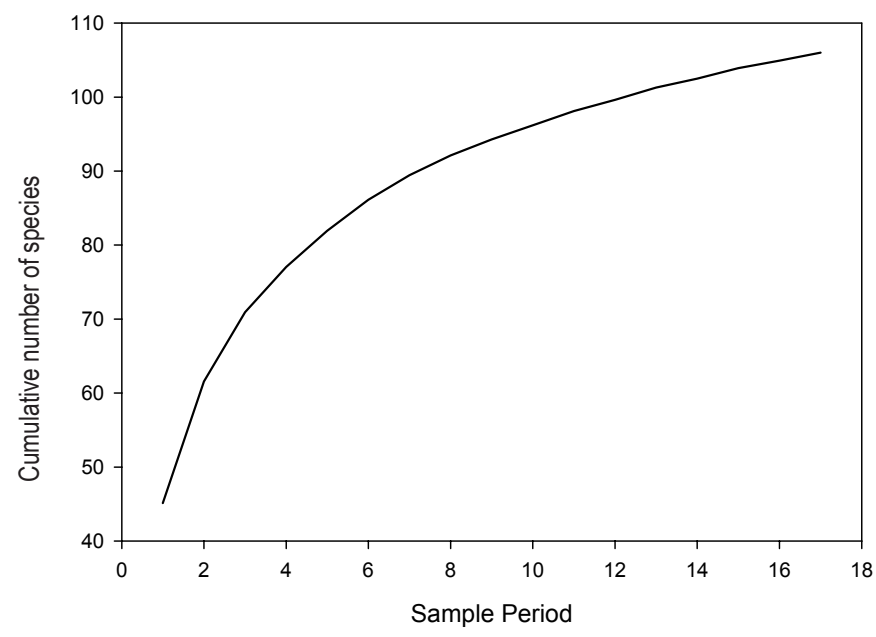

Figure 5.2. Species accumulation curves for detections from all bird surveys combined, Gila Cliff Dwellings NM, 2001 and 2002. Graph shows a completely randomized combination of observations from the three survey types (VCP, nocturnal, and incidental). Each sample period represents approximately 100 observations ( $N=1,714$ observations for all survey types). 
northern goshawk, American dipper, European starling, Hutton's vireo, black-chinned sparrow, and house sparrow are all species that we expected to, but did not, find during our surveys.

We did not survey for the endangered southwestern willow flycatcher (Empidonax traillii traillii) or Mexican spotted owls, although our survey crews were familiar with the calls characteristic of these birds, we did not find any individuals. Emily Bennett reported that Scott Stoleson (a regional expert on the southwestern willow flycatcher; USFS, Rocky Mountain Research Station, Albuquerque), visited the monument in 2002 and determined that the area was too high in elevation and did not have the necessary habitat components for the species. Mexican spotted owls have been reported from the monument (NPS 2003), and Gila National Forest personnel regularly conduct surveys for this species, primarily west of the monument.

We conducted surveys entirely during the peak of spring migration and during the breeding season. Although we would not expect winter surveys to be as productive as breedingseason surveys, there are a number of species that might overwinter at the monument, including the bald eagle, northern harrier, long-eared owl, and Cassin's finch (Appendix F). A host of other species likely use the monument and surrounding lands during the early spring and/or fall migration (Appendix F).

\section{Discussion}

This is the first comprehensive survey of birds at Gila Cliff Dwellings NM and the surrounding lands. As such it is an important step in understanding the structure of the bird community and the area's role in providing habitat for birds. The bird community at the monument has representative species from a wide range of families and genera, and for the size of the monument and our moderate search effort (approximately 20 field days over two years), we would characterize the community as moderately diverse. None of the 107 species (in over 1,700 observations) were non-native but we did find several species of conservation concern and a few species out of habitat or range including: a gray catbird found in late June 2002, the yellow-headed blackbird, Bell's vireo, and red crossbill (Appendix C). Further, we found few generalist (i.e., humanadapted) species. Except for mourning dove, those that we did find (such as the Brewer's blackbird, brown-headed cowbird, and house finch) were not abundant (Tables 5.2, 5.3, Appendix C).

The riparian area is probably the most important natural feature of the monument. The tall cottonwood gallery forest along the West Fork of the Gila River is rare in the southwest, and this type of vegetation community accounts for less than $1 \%$ of the landscape cover in the region (Ohmart 1994, Skagen et al. 1998). Riparian areas in arid regions support high bird species diversity due to their structural and floristic diversity as compared to surrounding areas (Lee et al. 1989, Strong and Bock 1990). This diversity translates into abundant insects for foraging and large trees for nesting (Powell and Steidl 2000). Bird species such as the common black hawk (Lee et al. 1989), yellow warbler, and yellow-breasted chat (Appendix C) prefer cottonwood/willow forests for nesting habitat. The presence of standing water provides habitat for a number of waterbirds such as the mallard, common merganser, and belted kingfisher.

We were encouraged to have found no non-native species at the monument or surrounding lands. The European starling and house sparrow are the most likely non-native species in the area. These species nest in cavities (and also on ledges in the case of house sparrows; Ehrlich et al. 1988) and are known to be aggressive toward native cavity-nesting species. Brown-headed cowbirds are not considered a non-native species, but they have expanded their range since the arrival of cattle into the southwest (Mehlman 1995). This is notable because cowbirds pose a threat to many native birds because they are brood parasites (i.e., lay their eggs in the nests of other, host species), and thereby reduce the productivity of host species. Brown-headed cowbirds were consistent members of the monument's bird community, particularly in the riparian area, but in that area there were 19 species that were more abundant (Table 5.2). Nevertheless, there are two riparian species at the monument that may be particularly susceptible to brown-headed cowbird parasitism: yellow-breasted 
chat and yellow warbler (see review in Schweitzer et al. 1998, Averill-Murray et al. 1999). We made one observation of a recently fledged brownheaded cowbird young (Table 5.4). An evaluation of the impact of cowbird parasitism was beyond the scope of this project.

During the breeding season, brownheaded cowbirds prefer edge communities, the abrupt interface of agricultural fields and human development with areas of dense vegetation, particularly along riparian areas (Rothstein 1994) such as those at the monument. The relative lack of human-induced fragmentation of the vegetation communities surrounding the monument may be one explanation for the low numbers of brownheaded cowbirds and lack of non-native species. In addition to affecting the species composition of bird communities, fragmentation also plays in a role in nesting success; nest predators such as skunks and domestic cats typically thrive in fragmented, human-dominated landscapes (Maestas et al. 2003). The natural edges (ecotones) between the vegetation communities at the monument do not appear to host an abundance of nest predators, and we found no feral cats (see Mammal chapter; Coleman and Temple 1993). Additional research would be needed to determine if the monument and surrounding areas are "source" populations (Pulliam 1988), but research in other areas has shown that birds in ecosystems with little or no unnatural fragmentation have higher nest success than those in fragmented landscapes (Donovan et al. 1995). 


\section{Chapter 6: Mammal Inventory}

\section{Previous Research}

Hayward and Hunt (1972) indicate that Bruce Hayward "trapped mammals and created a list" for the monument. Hayward netted bats at the monument in 1965; he indicated that there were no additional data (beyond species lists) from his efforts (pers comm. to Ronnie Sidner, 2001). Williams (1995) trapped small mammals approximately $15 \mathrm{~km}$ west of the monument during the spring, summer, and fall of 1995. To our knowledge no other mammal research has taken place at the monument and no mammal specimens have been collected from there.

\section{Methods}

We surveyed for mammals using six field methods: (1) netting and investigation of roost sites for bats, (2) live trapping for small terrestrial, nocturnal mammals (primarily rodents, herein referred to as "small mammals"), (3) trapping for pocket gophers, (4) pitfall trapping for shrews, (5) infrared-triggered photography for medium and large mammals, and (6) incidental observations for all mammals.

\section{Spatial Sampling Designs}

For small mammal plots we used a simple random design to assign plot locations for six plots: four plots in the West unit (L1, L3, L5, and L6) and two plots in the TJ ruins unit (G1 and G2) (Fig. 6.1 ). In addition, we subjectively placed 11 smallmammal trapping plots in the West unit: two in Cliff Dweller Canyon (CDC 1 and CDC 2), five in the floodplain of the West Fork of the Gila River (A, B, C, FW, and GRB), and four on the mesa above the cliff dwellings (Mesa D-G). For all other survey types we subjectively placed study sites based on (1) logistical constraints (bats) and (2) areas that we perceived would yield the most results (infrared-triggered cameras, pocket gopher trapping, and pitfall traps for shrews). We netted for bats and made incidental observations outside of the monument, but for all other survey types we established study sites within the monument boundary (Figs. 6.1, 6.2).

\section{Bats}

\section{Field Methods: Roost-site Visits}

We inspected suspected roost sites (for sign of live bats or guano) in two locations: under the automobile bridge over the Gila River (about $250 \mathrm{~m}$ south of the visitor center) and in the cliff dwellings.

\section{Field Methods: Mist Netting}

Most insectivorous bats congregate at water sites, so we set mist nets over water. We used three net sizes (5-m, 9-m, or 12-m) depending on the site and set nets singly or stacked, depending on conditions. For each bat captured, we recorded time of capture, species, and sex. When appropriate, we recorded relative age, reproductive condition, forearm length, mass, body condition, toothwear, presence of parasites and other measurements. We determined whether individuals were adult, subadult (by closure of epiphyses), or juvenile (by appearance). We determined age class by an estimation of tooth wear. For females, we recorded reproductive condition as pregnant (palpation for fetal bones), lactating (mammary gland with milk), previous evidence of lactation (misshapen or scarred nipples), or nulliparity (non-use of nipples). We determined reproductive condition for males by degree of swelling of testes or the presence of black epididymides. We recorded genera of parasites when known. We marked all captured bats with a temporary, non-lethal marker to prevent counting the same individual more than once in the same evening. We used sonar detectors (Anabat and/or QMC Mini) at all sites to aid in determining bat presence/absence and relative activity as compared to the visual or mist-net results. We listened passively for the call of the pallid bat, the only species of bat in western New Mexico that can be definitively identified by its directive call.

\section{Effort}

We investigated two roost sites and netted for bats at seven sites for approximately 55 hours of netting (Table 6.1). 


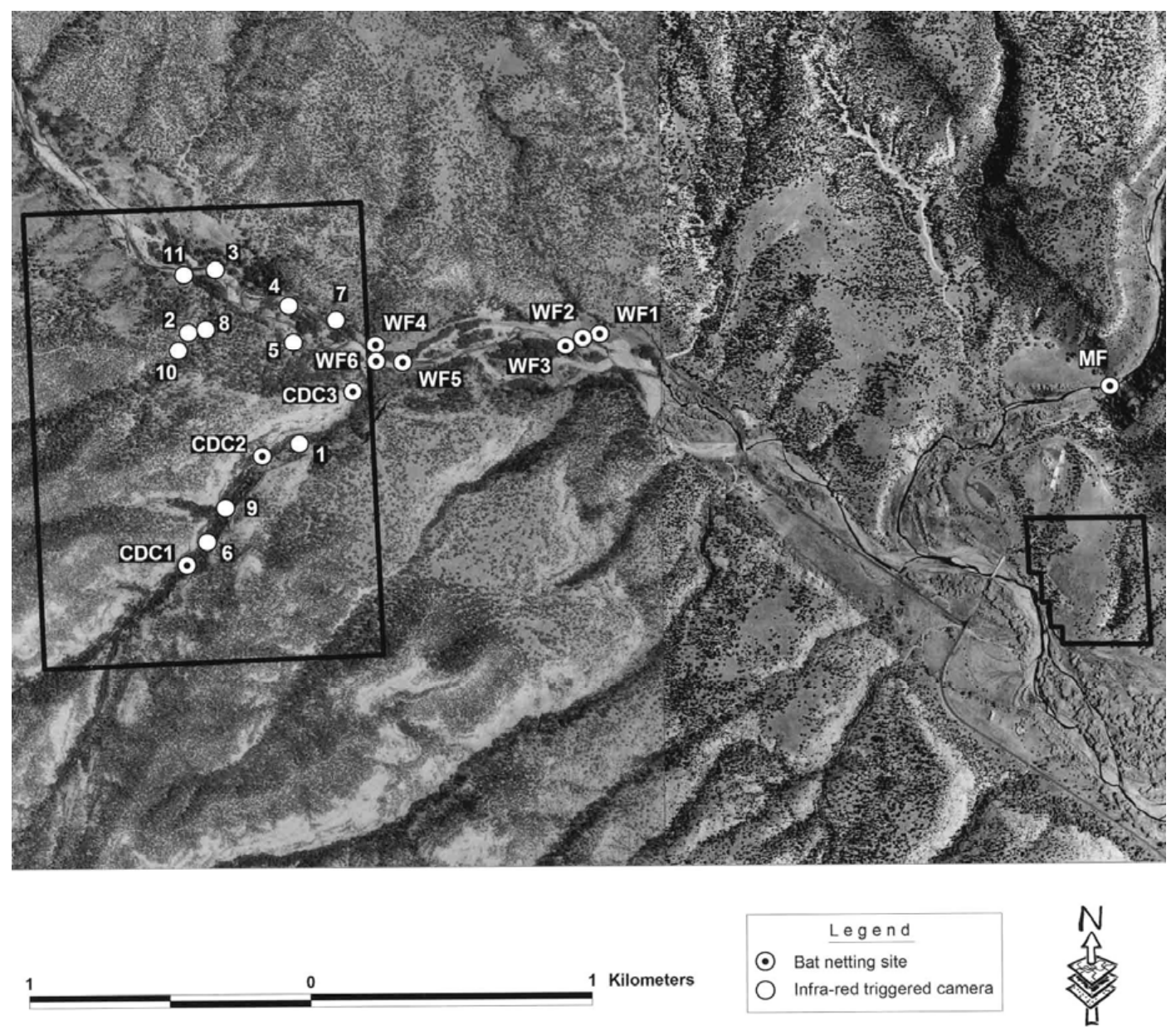

Figure 6.1. Locations of bat-netting sites and Trailmaster (infra-red triggered) cameras, Gila Cliff Dwellings NM, 2001 and 2002.

\section{Analyses}

We report the number of species and individuals caught by site, but because of the extreme differences in trapping effort among sites (Table 6.1), we calculated percent netting success (PNS) ${ }^{1}$ for comparisons among sites. We calculated PNS as the number of animals caught divided by effort (total length of net coverage multiplied by amount of time nets were open [Table 6.1]). Due to the low number of captures at all sites except WF6 and WF1, we can compare trapping success only for these two sites.

\footnotetext{
${ }^{1}$ Because netting bats is somewhat a function of chance (many more individuals and species can be present in an area than are caught), we do not attempt to present percent netting success as a measure of relative abundance.
}

\section{Small Mammals}

\section{Field Methods: Sherman Traps}

We trapped small mammals at both the TJ Ruins and West units in 2001 and at the West unit in 2002 (Table 6.2). We used Sherman ${ }^{\circledR}$ live traps (large, folding aluminum or steel, 3 x 3.5 x 9"; H. B. Sherman, Inc., Tallahassee, FL) set in grids (White et al. 1983), with 10-m spacing among traps arranged in configurations of five rows and five columns. On two plots in Cliff Dweller Canyon we placed 24 traps into two rows of 12 traps each because of the canyon's narrowness. We opened and baited traps in the evening (one tablespoon; 16 parts dry oatmeal to one part peanut butter), then checked and closed traps the following morning. We placed a small amount of polyester batting 


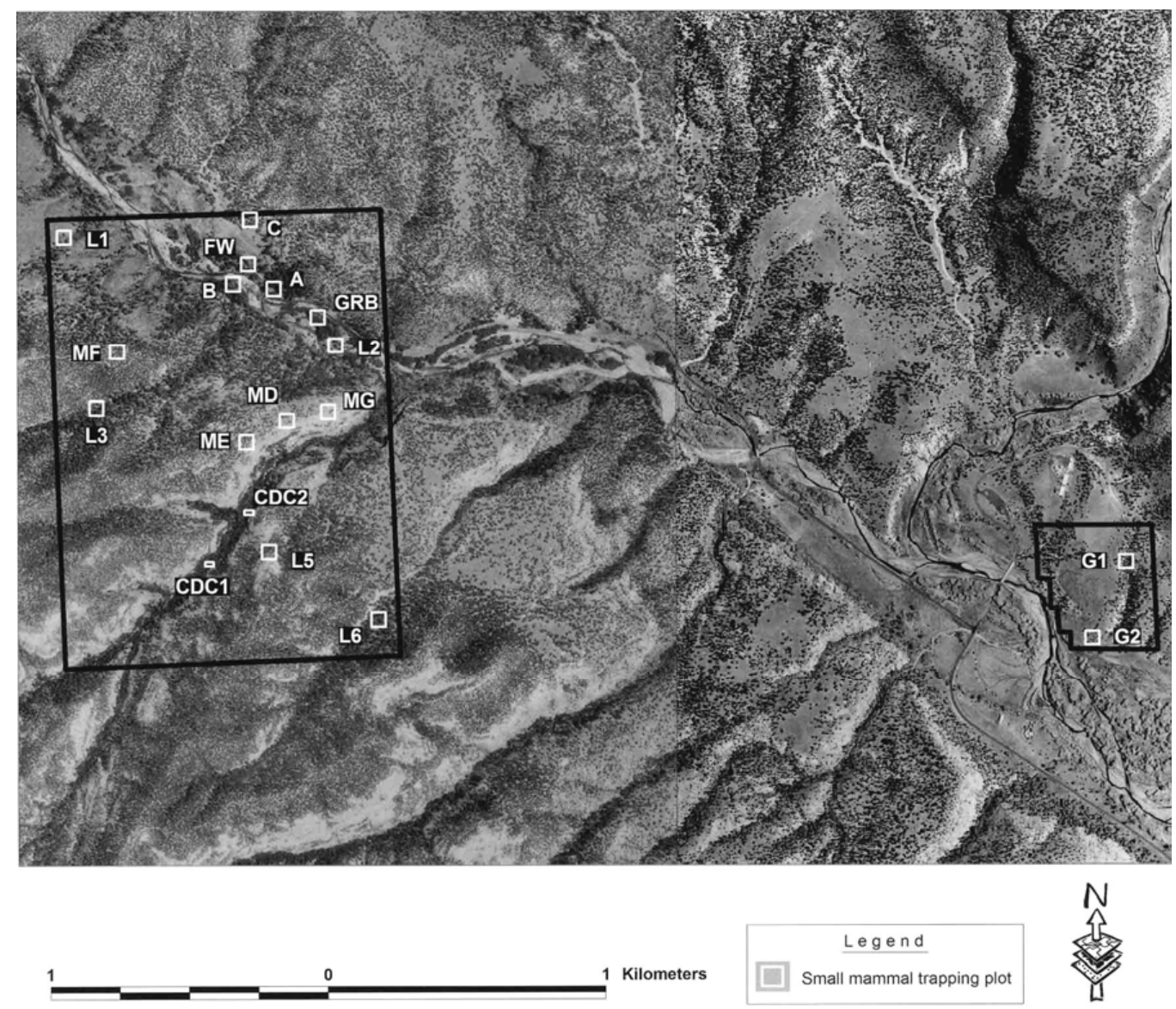

Figure 6.2. Locations of small-mammal trapping plots, Gila Cliff Dwellings NM, 2001 and 2002.

in each trap to prevent mortality from the cold. We marked each captured animal with a semipermanent marker to facilitate recognition; these "batch marks" appeared to last for the duration of the sampling period (one to three days). For each animal we recorded species, sex, age class (adult, subadult, or juvenile), reproductive condition, weight, and measurements for right-hind foot, tail, ear, head, and body. For males, we recorded reproductive condition as either scrotal or non-reproductive. For females we recorded reproductive condition as one or more of the following: non-reproducing, open pubis, closed pubis, enlarged nipples, small or non-present nipples, lactating, post lactating, or not lactating.

\section{Effort: Sherman Traps}

We trapped for a total of 1,675 trap nights: 9 plots in 2001 (962 trap nights) and 8 plots in 2002 (713 trap nights). The number of trap nights varied by plot and visit number (Table 6.2).

\section{Analysis: Sherman Traps}

We calculated relative abundance by plot and sampling period (i.e., 1-4 trapping nights at each plot) by dividing the number of captures by the number of trap nights (number of traps multiplied by number of nights they were open) after accounting for sprung traps (misfired or occupied; Beauvais and Buskirk 1999). Sprung traps reduce trap effort because they are no longer "available" to capture animals; we account for this by multiplying the number of sprung traps 
Table 6.1. Summary of bat survey effort, Gila Cliff Dwellings NM, 2001 and 2002.

\begin{tabular}{|c|c|c|c|c|c|c|c|}
\hline Site type & Site name & Abbreviation & Year & $\begin{array}{l}\text { Day/ } \\
\text { Month }\end{array}$ & $\begin{array}{l}\text { Total length of net } \\
\text { coverage }(m)^{\mathrm{a}}\end{array}$ & $\begin{array}{l}\text { Amount of time } \\
\text { nets open (hrs) }\end{array}$ & Effort $^{b}$ \\
\hline \multirow[t]{2}{*}{ Roosting } & Bridge over Gila River & BGR & 2001 & 29 May & & & $\mathrm{NA}$ \\
\hline & Cliff Dweller Canyon 3 & CDC3 & 2001 & $8 \mathrm{Jul}$ & & & NA \\
\hline \multirow[t]{13}{*}{ Netting } & Cliff Dweller Canyon 1 & CDC1 & 2001 & 13 Sep & 18 & 9.5 & 171.0 \\
\hline & Cliff Dweller Canyon 2 & CDC2 & 2001 & 29 May & 10 & 3.0 & 30.0 \\
\hline & Middle Fork Gila River & $\mathrm{MF}$ & 2001 & 28 May & 14 & 5.5 & 77.0 \\
\hline & West Fork Gila River 1 & WF1 & 2001 & 27 May & 18 & 4.0 & 72.0 \\
\hline & & & 2002 & 22 Jun & 5 & 5.6 & 28.0 \\
\hline & & & 2002 & 29 Aug & 19 & 3.0 & 57.0 \\
\hline & West Fork Gila River 4 & WF4 & 2002 & 27 Aug & 14 & 4.6 & 64.4 \\
\hline & West Fork Gila River 5 & WF5 & 2002 & 28 Aug & 5 & 1.0 & 5.0 \\
\hline & West Fork Gila River 6 & WF6 & 2001 & 25 May & 9 & 1.5 & 13.5 \\
\hline & & & & 26 May & 19 & 5.3 & 99.8 \\
\hline & & & & 12 Sep & 12 & 2.3 & 27.0 \\
\hline & & & 2002 & 21 Jun & 17 & 6.5 & 110.5 \\
\hline & & & & 20 Jun & 12 & 3.0 & 36.0 \\
\hline
\end{tabular}

a We usually used a combination of nets depending on the physical conditions and logistical constraints. Individual nets were either 5,9 , or 12 meters in length.

${ }^{\mathrm{b}}$ Total length of net coverage multiplied by amount of time nets were open.

Table 6.2. Small-mammal trapping effort, Gila Cliff Dwellings NM, 2001 and 2002.

\begin{tabular}{|c|c|c|c|c|c|c|c|c|}
\hline Area or community type ${ }^{a}$ & $\begin{array}{l}\text { Plot } \\
\text { name }\end{array}$ & $\begin{array}{c}\text { Visit } \\
\text { number }\end{array}$ & Year & Month & $\begin{array}{l}\text { Nights of } \\
\text { trapping }\end{array}$ & $\begin{array}{c}\text { Traps set per } \\
\text { night }\end{array}$ & $\begin{array}{l}\text { Sprung } \\
\text { traps }\end{array}$ & $\begin{array}{l}\text { Trap } \\
\text { nights }\end{array}$ \\
\hline \multirow[t]{3}{*}{ Cliff Dweller Canyon } & CDC 1 & 1 & 2001 & May & 4 & 24 & 2 & 95.0 \\
\hline & & 2 & 2001 & Sep & 3 & 24 & 12 & 66.0 \\
\hline & CDC 2 & 1 & 2002 & Jun & 1 & 10 & 3 & 8.5 \\
\hline \multirow[t]{11}{*}{ West Fork Gila River } & A & 1 & 2002 & Apr & 3 & 25 & 28 & 61.0 \\
\hline & B & 1 & 2002 & Apr & 3 & 25 & 39 & 55.5 \\
\hline & & 2 & 2002 & May & 3 & 25 & 52 & 49.0 \\
\hline & & 3 & 2002 & Jun & 2 & 25 & 28 & 36.0 \\
\hline & & 4 & 2002 & Jul & 3 & 25 & 35 & 57.5 \\
\hline & & 5 & 2002 & Aug & 3 & 25 & 39 & 55.5 \\
\hline & & 6 & 2002 & Sep & 3 & 25 & 34 & 58.0 \\
\hline & C & 1 & 2002 & May & 3 & 25 & 19 & 65.5 \\
\hline & FW & 1 & 2001 & Sep & 2 & 25 & 0 & 50.0 \\
\hline & GRB & 1 & 2001 & May & 2 & 25 & 10 & 45.0 \\
\hline & & 2 & 2001 & Sep & 3 & 25 & 5 & 72.5 \\
\hline \multirow[t]{4}{*}{ Mesa } & MD & 1 & 2002 & Aug & 3 & 25 & 33 & 58.5 \\
\hline & $\mathrm{ME}$ & 1 & 2002 & Sep & 3 & 25 & 4 & 73.0 \\
\hline & MF & 1 & 2002 & Sep & 3 & 25 & 8 & 71.0 \\
\hline & MG & 1 & 2002 & Sep & 3 & 25 & 22 & 64.0 \\
\hline \multirow[t]{8}{*}{ Random - West unit } & L1 & 1 & 2001 & May & 2 & 25 & 4 & 48.0 \\
\hline & & 2 & 2001 & Sep & 3 & 25 & 2 & 74.0 \\
\hline & L3 & 1 & 2001 & May & 4 & 25 & 5 & 97.5 \\
\hline & & 2 & 2001 & Sep & 3 & 25 & 2 & 74.0 \\
\hline & L5 & 1 & 2001 & May & 2 & 25 & 0 & 50.0 \\
\hline & & 2 & 2001 & Sep & 2 & 25 & 2 & 49.0 \\
\hline & L6 & 1 & 2001 & May & 2 & 25 & 0 & 50.0 \\
\hline & & 2 & 2001 & Sep & 2 & 25 & 0 & 50.0 \\
\hline \multirow[t]{2}{*}{ Random - TJ Ruins unit } & G1 & 1 & 2001 & May & 3 & 25 & 12 & 69.0 \\
\hline & G2 & 1 & 2001 & May & 3 & 25 & 6 & 72.0 \\
\hline
\end{tabular}

${ }^{a}$ Most groups or community types follow those established for amphibians and reptiles (see Chapter 4). 
by 0.5 (lacking specific information, we estimate sprung traps were available for half of the night; Nelson and Clark 1973). We provide summaries of trapping effort for each site (all sampling periods) and for each sampling period within sites.

\section{Field Methods: Gopher Traps}

Pocket gophers (Thomomys) are rarely captured in Sherman traps. Therefore, we used Victor ${ }^{\circledR}$ gopher kill-traps ('Easy Set Gopher Trap 0610'; Wildlife Management Supplies, Traverse City, MI) at one site near the West Fork of the Gila River. We selected the area based on the abundance of fresh pocket gopher mounds and for convenience in checking traps. For each of three traps, we uncovered a burrow in a fresh mound and placed the trap 10-25 cm deep in the burrow. For the first two nights of trapping we covered the trap with dirt; however, for the remaining 15 nights we left the burrows and traps uncovered. To prevent traploss, we tied a cord ( $45-60 \mathrm{~cm}$ long) to the base of the trap and attached it to a stake.

\section{Effort and Analysis: Gopher Traps}

We trapped for pocket gophers for 17 days in August 2002. We report the number of animals captured.

\section{Field Methods: Pitfall Traps}

To capture shrews, we set up three 1-L and three 5$\mathrm{L}$ pitfall buckets in the same general area as gopher traps. We placed the buckets adjacent to natural drift features (logs, rocks) and buried them flush with the ground surface. We opened the buckets in the evening and closed them the following morning. For an additional 20 days, we added three additional 5-L buckets and left them open continuously (1-L buckets were too small and we thought they might allow animals to escape). We did not bait the buckets.

\section{Effort and Analysis: Pitfall Traps}

We trapped for 26 nights in late August 2002.

\section{Medium and Large Mammals}

\section{Field Methods}

We used infrared-triggered cameras (Trailmaster ${ }^{\circledR}$; model 1500, Goodman and Associates, Inc, Lenexa, KS; Kucera and Barrett 1993) to record the presence of medium and large mammals. Trailmasters have three components: receiver, transmitter, and camera (Fig. 6.3). The transmitter sends an infrared beam to the receiver at a specified rate ( 5 times per second for this study). The receiver then sends a signal (via cable) to a camera mounted on a tripod 6-8 $\mathrm{m}$ away. When an animal blocks the infrared beam, the camera takes a picture. We placed the receiver and transmitter approximately $20 \mathrm{~cm}$ above the ground to ensure that medium and large mammals were captured on film but smaller animals such as rodents and birds were avoided. We cleared vegetation from the area to avoid disruption of the infrared beam and to minimize disturbance that might cause animals that regularly use an area to avoid it. We set cameras to take no more than one photograph every five minutes to reduce the chances of recording the same individual more than once on the same occasion. We placed cameras in areas that would capture the most species and highest numbers of animals, typically along animal trails and near water. We baited camera sites with a scent lure (ingredients included synthetic catnip oil, bobcat musk, beaver castorium, and propylene glycol as a preservative) or canned cat food. We checked cameras approximately every two weeks to change film and batteries and to ensure their proper function. We photographed a placard documenting the date and camera location on the first exposure of every new roll of film.

\section{Effort}

We placed Trailmaster cameras at 11 sites throughout the West unit (three sites each in Cliff Dweller Canyon and the unnamed canyon to the west of Cliff Dweller Canyon and five sites along the West Fork of the Gila River; Fig 6.2). The number of days that each camera was in operation ranged from 6 to 62 days (mean $=28 \pm 14.2$ [SD]) for a total of 308 days of operation. We operated one camera in 2001 and two cameras simultaneously in 2002.

\section{Analysis}

Infrared-triggered cameras are the most costeffective and definitive method for recording the presence of medium and large mammal species 
(Kucera and Barrett 1993, Cutler and Swann 1999). However, one drawback to this method is an inability to distinguish among individuals, which precludes unbiased estimates of abundance (i.e., one must attempt to determine if one animal has been photographed repeatedly or a new individual is in each photo). Notable exceptions are species with distinctive markings that can be differentiated among individuals, such as bobcats (Heilbrun et al. 2003). We were not able to use size or physical abnormality to differentiate individuals. Therefore, we report the number of times a species was photographed.

\section{Incidental Observations and Sign}

As with other taxa, we recorded UTM coordinates of mammal observations. Personnel from all field crews (e.g., bird crew as well as mammal crew) recorded mammal sightings and signs such as identifiable tracks or scat, and took photo vouchers when the sign alone was definitive. We also recorded incidental observations made on lands outside of the monument.

\section{Results}

We observed or documented 36 mammal species in or immediately adjacent to the monument in 2001 and 2002 (Appendix D). We observed the largest number of species by incidental observations, documented nine species each with Trailmaster cameras and small-mammal trapping, and trapped/ documented eight species of bats during netting. We found neither non-native species nor species with special conservation designations (BISON 2004).

\section{Bats}

We captured 65 individuals representing eight species during approximately 55 hours of trapping in 2001 and 2002 (Table 6.4). The Mexican free-tailed and silver haired bats were the two most commonly captured species. Three species were represented by two or fewer individuals: southwestern myotis, California myotis, and big freetail bat. The Mexican freetail bat was found at the most sites $(n=3)$; the California myotis and big freetail bat at the fewest number of sites

\section{(2) Receiver

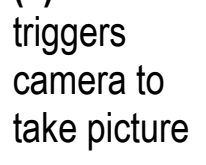

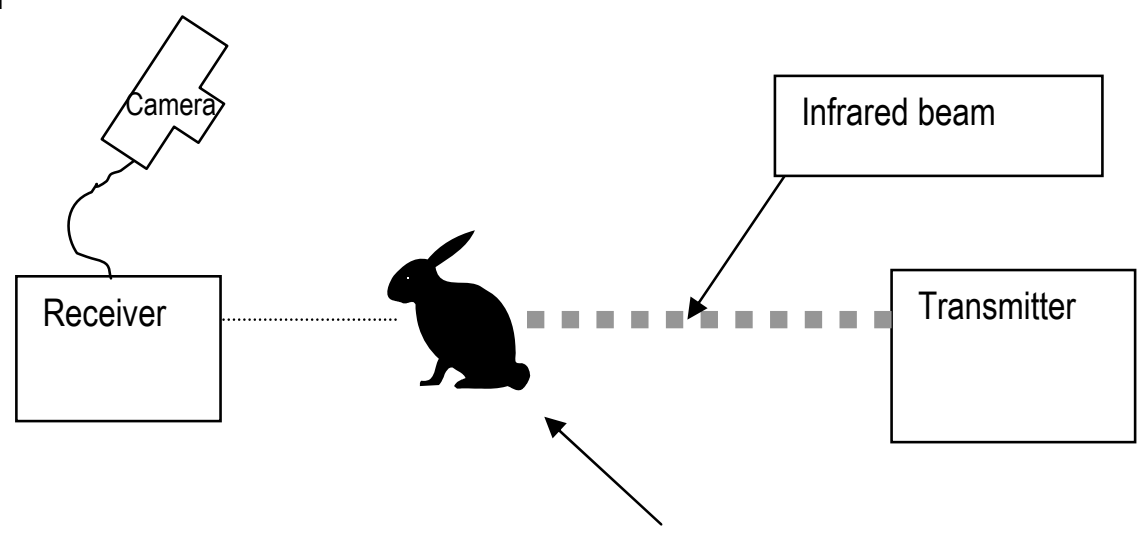

(1) Animal blocks infrared beam from getting to receiver

Figure 6.3. Diagram of Trailmaster camera set-up. Image based on Swann et al. (2004). 
Table 6.3. Summary of Trailmaster camera effort, Gila Cliff Dwellings NM, 2001 and 2002.

\begin{tabular}{|c|c|c|c|c|c|}
\hline \multirow{6}{*}{$\begin{array}{l}\text { General location } \\
\text { West Fork Gila River }\end{array}$} & Camera number & Year & Start date & End date & Number of days open \\
\hline & 3 & 2001 & 10 Oct & $11 \mathrm{Dec}$ & 62 \\
\hline & 4 & 2002 & $20 \mathrm{Apr}$ & 19 May & 29 \\
\hline & 5 & 2002 & 19 May & 08 Jun & 20 \\
\hline & 7 & 2002 & 02 Jul & $15 \mathrm{Jul}$ & 13 \\
\hline & 11 & 2002 & 26 Aug & 20 Sep & 25 \\
\hline \multirow[t]{3}{*}{ Cliff Dweller Canyon } & 1 & 2001 & 01 Jun & $01 \mathrm{Jul}$ & 30 \\
\hline & 6 & 2002 & 12 Jun & $19 \mathrm{Jul}$ & 37 \\
\hline & 9 & 2002 & 24 Jul & 21 Aug & 28 \\
\hline \multirow[t]{3}{*}{ Unnamed canyon west of Cliff Dweller Canyon } & 2 & 2001 & 01 Sep & 01 Oct & 31 \\
\hline & 8 & 2002 & $30 \mathrm{Jul}$ & 05 Aug & 6 \\
\hline & 10 & 2002 & 20 Aug & 16 Sep & 27 \\
\hline
\end{tabular}

$(n=1)$. All captured bats were adults, and males outnumbered females 49 to 17 (Appendix L).

We did not catch bats at four netting sites (CDC1, CDC2, MF, and WF5) or observe them at the two roost sites. We caught seven species at each of the two most sampled sites (WF6 and WF1) and, with the exception of one species at each site, the bat community was similar (Table 6.4). Across all sampling events (i.e., netting nights), WF1 was the most productive netting site; it had a higher mean netting success (2.6 \pm 2.14 [SD]) than WF6 (1.7 \pm 1.49$)$. Within these two sites there were considerable temporal differences in the number and species caught. On five sampling events at WF6 the number of species caught per sampling event ranged from zero to six (Appendix L). Hoary bats were captured on four sampling events and the Mexican freetail and big brown bats were captured on three sampling events. We found three species that were present at the site in both years and three species that were found in only a single year. On three sampling events at WF1, the complement of species changed drastically, particularly between 2001 and 2002, as only one of the seven species caught at the site was caught in both years (Appendix L).

\section{Small Mammals}

\section{Sherman Traps}

We trapped eight species in 1,675 trap nights at both units (Table 6.5). Despite having more trap nights in 2001 than in 2002, we found more species in 2002: six species in 2001 and those same species plus two more in 2002 (Appendix $\mathrm{M})$. The brush mouse was the most abundant species in plots along the West Fork of the Gila River (Table 6.5; Appendix M). The western harvest mouse was also abundant in those plots. Two species were found only in a single area each: piñon mouse in plots on the mesa (above the cliff dwellings) and the Mexican vole along the West Fork of the Gila River.

Table 6.4. Number of bats captured ( $n$ ) and percent netting success (PNS) at three mist-netting sites at Gila Cliff Dwellings NM, 2001 and 2002. See Table 6.1 for summary of netting effort by site, Appendix L for additional trapping data at each site and date.

\begin{tabular}{|c|c|c|c|c|c|c|}
\hline \multirow[b]{3}{*}{ Species } & \multicolumn{6}{|c|}{ Site } \\
\hline & \multicolumn{2}{|c|}{ WF1 } & \multicolumn{2}{|c|}{ WF4 } & \multicolumn{2}{|c|}{ WF6 } \\
\hline & $n$ & PNS & $n$ & PNS & $n$ & PNS \\
\hline Arizona myotis & 8 & 5.1 & & & 2 & 0.7 \\
\hline southwestern myotis & 1 & 0.6 & & & 1 & 0.3 \\
\hline California myotis & 1 & 0.6 & & & & \\
\hline big brown bat & 2 & 1.3 & & & 4 & 1.4 \\
\hline hoary bat & 2 & 1.3 & & & 6 & 2.1 \\
\hline silver-haired bat & 7 & 4.5 & & & 9 & 3.1 \\
\hline Mexican freetail bat & 8 & 5.1 & 1 & 1.6 & 12 & 4.2 \\
\hline big freetail bat & & & & & 1 & 0.3 \\
\hline
\end{tabular}


We found no species at two plots (L6 and FW) and as many as five species on a single plot in one visit (Mesa G; Appendix M). The most species that we found on a plot was six (plot B) over six visits and 17 trapping nights (Appendix M). Not accounting for the differences in trapping effort among sites, the mean number of species trapped per plot was $2.6 \pm 0.38(\mathrm{SD})$.

Considering all species, we had low trap success in random areas and much higher trap success on non-random sites, particularly along the West Fork of the Gila River (Table 6.5). Based on presence across plots, the brush mouse was the most widespread; it was found at 13 of the 17 plots (Appendix M). The western white-throated woodrat was the next most widespread; it was found on eight plots. All other species were found on four or fewer plots.

\section{Gopher and Pitfall Traps}

We captured one Botta's pocket gopher in 17 nights using gopher traps. We did not capture any shrews in 26 nights of pitfall-trap operation.

\section{Medium and Large Mammals}

We took 68 photographs of animals (67 mammals and one bird) in approximately 308 days of Trailmaster camera operation (Table 6.6). We took photographs of nine species of mammals

Table 6.5. Total number of small mammals trapped ( $\mathrm{n}$ ) and percent relative abundance (RA), excluding recaptures, by trapping group, Gila Cliff Dwellings NM, 2001 and 2002. Data summaries are for all sites, all visits, all trap nights within each group; see Appendix M for additional trapping data by site and visit. See Table 6.2 for trapping effort by site.

\begin{tabular}{|c|c|c|c|c|c|c|c|c|c|c|}
\hline \multirow[b]{3}{*}{ Species } & \multicolumn{10}{|c|}{ Group } \\
\hline & \multicolumn{2}{|c|}{$\begin{array}{l}\text { Random- } \\
\text { West unit }\end{array}$} & \multicolumn{2}{|c|}{$\begin{array}{l}\text { Random- } \\
\text { TJ Ruins unit }\end{array}$} & \multicolumn{2}{|c|}{ Mesa } & \multicolumn{2}{|c|}{ West Fork } & \multicolumn{2}{|c|}{$\begin{array}{c}\text { Cliff Dweller } \\
\text { Canyon }\end{array}$} \\
\hline & $n$ & RA & $n$ & $\mathrm{RA}$ & $n$ & $\mathrm{RA}$ & $n$ & RA & $n$ & RA \\
\hline cliff chipmunk & 1 & 0.2 & & & 2 & 0.8 & & & & \\
\hline western harvest mouse & 1 & 0.2 & & & & & 37 & 6.7 & & \\
\hline deer mouse & & & & & 2 & 0.8 & 2 & 0.4 & & \\
\hline brush mouse & 4 & 0.8 & 2 & 1.4 & 8 & 3.0 & 64 & 11.5 & 8 & 4.7 \\
\hline piñon mouse & & & & & 3 & 1.2 & & & & \\
\hline western white-throated woodrat & 1 & 0.2 & 2 & 1.4 & 11 & 4.1 & 12 & 2.2 & 1 & 0.6 \\
\hline Mexican woodrat & & & 1 & 0.7 & & & 1 & 0.2 & & \\
\hline Mexican vole & & & & & & & 3 & 0.5 & & \\
\hline
\end{tabular}

Table 6.6. Results from Trailmaster cameras, Gila Cliff Dwellings NM, 2001 and 2002. See Table 6.3 for effort.

\begin{tabular}{|c|c|c|c|c|c|c|c|c|c|c|}
\hline \multirow[b]{3}{*}{ Group } & \multirow[b]{3}{*}{ Species } & \multicolumn{8}{|c|}{ General location, camera number } & \multirow{3}{*}{$\begin{array}{c}\text { Number of } \\
\text { Photographs }\end{array}$} \\
\hline & & \multicolumn{4}{|c|}{ West Fork Gila River } & \multicolumn{3}{|c|}{ Cliff Dweller Canyon } & \multirow{2}{*}{$\frac{\text { Other }^{\mathrm{a}}}{2}$} & \\
\hline & & 3 & 5 & 7 & 11 & 1 & 6 & 9 & & \\
\hline Bird & wild turkey & & & & & & & & 1 & 1 \\
\hline Mammal & American black bear & & & & & & & & 2 & 2 \\
\hline & striped skunk & & 7 & & & 3 & & & & 10 \\
\hline & white-backed hog-nosed skunk & 9 & & & & & & & & 9 \\
\hline & common gray fox & & 7 & & & & 1 & & 4 & 12 \\
\hline & mountain lion & & & 1 & & & & 1 & & 2 \\
\hline & rock squirrel & & & & & 1 & & & & 1 \\
\hline & Abert's squirrel & & & & & 1 & & & & 1 \\
\hline & unknown white-footed mouse & & & & 8 & & & & & 8 \\
\hline & unknown woodrat & & & & 16 & & & 1 & & 17 \\
\hline & collared peccary & & 2 & & & & & & 1 & 3 \\
\hline & elk & & 2 & & & & & & & 2 \\
\hline Total & & 9 & 18 & 1 & 24 & 5 & 1 & 2 & 8 & 68 \\
\hline
\end{tabular}

a Unnamed canyon west of Cliff Dweller Canyon. 
that we were able to identify to species. The most frequently photographed species were the common gray fox, striped skunk, and whitebacked hog-nosed skunks. However, many of these photographs were on the same roll of film, suggesting that multiple photographs may have been of the same individual.

The number of photographs from each site ranged from zero (camera numbers 4,8 , and 10 ) to 24 (Table 6.6). Cameras located near or adjacent to the West Fork of the Gila River resulted in the greatest number of photographs and documented the most species. At the Cliff Dweller Canyon sites we took only eight photographs that could be identified to species, and we recorded five species.

\section{Specimen Vouchers and Photographs}

We collected 34 specimen vouchers representing 24 species while conducting inventories (Appendix H). We collected many of these specimens during the course of field work (e.g., small-mammal trapping). Others were found as bones; sometimes bones served as the sole documentation of a species, as in the case of the hooded skunk. We collected photographs of nine species from Trailmaster cameras (Table 6.6).

\section{Incidental Observations}

We recorded 43 sightings of 14 species outside of formal surveys and observed seven species that we did not find on any other survey type: coyote, American beaver, common muskrat, northern raccoon, black-tailed jackrabbit, mule deer, and white-tailed deer (Appendix D).

\section{Inventory Completeness}

Based on a list of species that have either been observed or are likely in the area (Appendix G), we believe that we recorded or documented most of the common species that occur in the monument. The only species known to have been in the area during the time of our inventory, but which we did not find, were the bobcat and Mexican gray wolf. To assess inventory completeness we address each group separately.

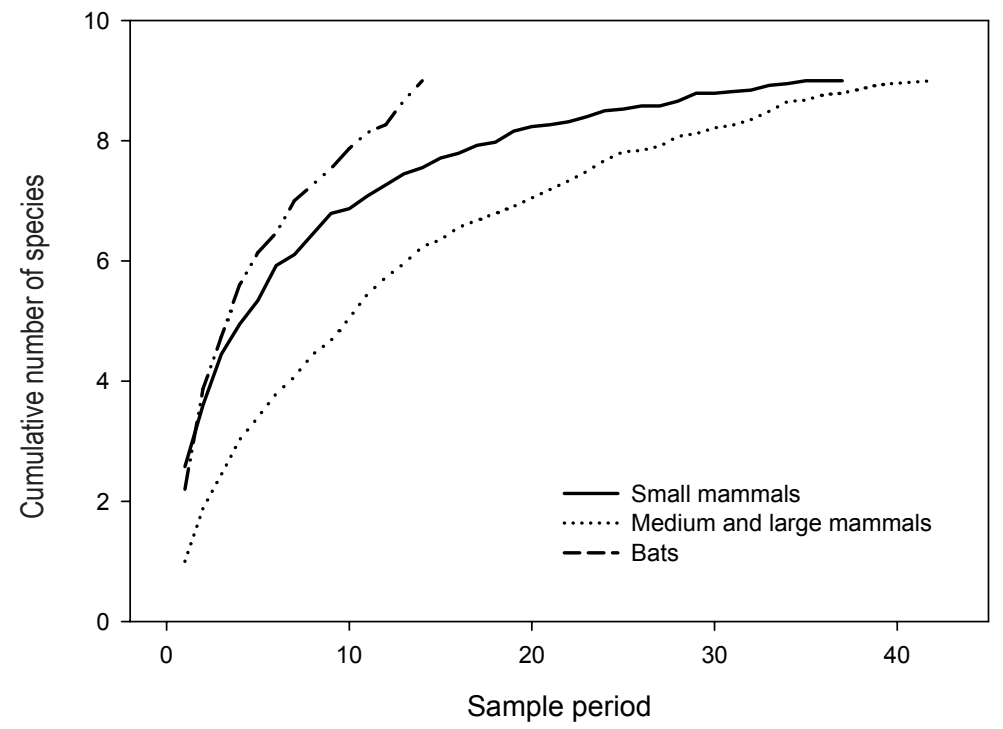

Figure 6.4. Species accumulation curve for mammal surveys, Gila Cliff Dwellings NM, 2001 and 2002. Each sampling period represents different sampling intensities for each group: one night of netting for bats, 1-3 days of trapping for small mammals, and individual photographs of medium and large mammals. The order of each sampling periods was randomized. 
Despite netting at sites throughout the monument during both 2001 and 2002, we believe that there are as many as 12 species of bats that may be found at the monument with additional survey effort, including three species that were found by Bruce Hayward in 1965 (Appendix G). Indeed, the species accumulation curve for bats shows little sign of leveling off (Fig. 6.4) and illustrates the difficulty in completing an inventory of bats, which can show up most places (few insectivorous bats have restricted foraging habitat requirements). Therefore, finding these additional species will require many additional nights of netting (but see Chapter 8 for recommendations).

\section{Small Mammals}

Based on the species accumulation curve (Fig. 6.4) and our sampling intensity, we believe that we recorded all but the most rare species of small mammals at the monument. Hayward and Hunt (1972) report that they trapped the silky pocket mouse, Ord's kangaroo rat, and southern grasshopper mouse on the TJ Ruins unit, but we did not record them there nor anywhere else in the monument. The gray squirrel was noted a few kilometers up the West Fork of the Gila River by Hayward and Hunt (1972).

\section{Medium and Large Mammals}

We recorded most of the common medium and large mammals. With the exception of the bobcat and Mexican gray wolf, all of the medium and large mammals that we did not record are considered rare or only possible in the area. Longtailed weasel may use the area during peak years (Bruce Hayward in pers. comm. to Ronnie Sidner, 2001). Despite a concerted effort, Hayward and Hunt (1972) did not find any porcupine in the Gila Wilderness during their surveys, though they believed the animal to be most likely in the areas such as Gila Cliff Dwellings NM. American badger is possible at the TJ Ruins unit. Both the porcupine and American badger may be experiencing declines throughout the region (Don Swann, pers. comm.) and this may be cause for management concern.
This effort is the most comprehensive mammal inventory effort undertaken at Gila Cliff Dwellings NM or in the surrounding area. Of all the taxonomic groups, we spent the most effort inventorying for mammals. Our work produced 36 species, which represented a wide range of families and genera and did not include any non-native species (Appendix D). Based on our work and reports by others (Appendix G), the mammal community at the monument contains an abundance of large mammal species: American black bear, Mexican gray wolf, mountain lion, elk, and mule and white-tailed deer.

A majority of our survey effort involved small mammal trapping at plots set throughout the monument, mostly in the West unit. We assigned plot locations using random and non-random study designs and altered trap configurations, number of trap nights per plot, and number of visits to each plot. These different survey designs provided valuable insights into the spatial and temporal structure of the small-mammal community at the monument. The high trap success along the riparian area of the West Fork of the Gila River suggest that this area is preferred habitat for a number of species, such as the western harvest mouse and brush mouse. Although we did not conduct vegetation sampling at small mammal trapping sites, we sampled vegetation at birdcount stations and found much higher vegetation volume (i.e., structure) at most of the Riparian transect stations (numbers 2-5) than at stations in the canyon transect that were on the mesa (station numbers 1 and 2). This result corresponded to our qualitative characterization of the sites in the floodplain: high vegetation volume close to the ground. Vegetation volume close to the ground, particularly grasses used for food and cover, along with loose soil types, is a consistent predictor of small mammal species richness and abundance in the southwest (Price 1978, Stamp and Ohmart 1979, Sureda and Morrison 1999).

Although the sites on the mesa (above the cliff dwellings) had lower trap success than the sites on the West Fork of the Gila River, they were productive for documenting the presence of small mammals. We trapped two species (cliff chipmunk 
and piñon mouse) that we found only on plots located on or near the mesa (Table 6.5).

Hayward and Hunt (1972) report that the brush mouse and western white-throated woodrat were common in the area around the visitor center. Our results concur; at plots in the TJ Ruins unit and along the West Fork of the Gila River, these two species were common (Table 6.5, Appendix M). However, Hayward and Hunt make no mention of the western harvest mouse. On our West Fork plots the western harvest mouse was almost as abundant as the brush mouse (Appendix M). We found no silky pocket mouse, Ord's kangaroo rat, or southern grasshopper mouse at the TJ Ruins unit, but Hayward and Hunt report that they trapped these species on the "TJ Mesa" (the location of the current TJ Ruins unit [Bruce Hayward, pers. comm.]). Given the high grass cover and scattered juniper on the TJ Ruins site, we were particularly concerned not to have found silky pocket mouse and Ord's kangaroo rat, in particular, because of their affinities for grasses and junipers (Hoffmeister 1986). No original data or specimens exist from the Hayward and Hunt effort, but Hayward's skill at species identification leave little doubt that these species were present there. Our attempt to trap these species may have been because of our limited trap effort or because the species may no longer be present (see suggestion for additional inventories).

Our bat-netting effort produced eight species of bats, all of them netted at sites over water along the West Fork of the Gila River (Table 6.4). Based on her knowledge of the area and the natural history of bats, Ronnie Sidner expected to find all of the species that we observed (Ronnie
Sidner, pers. comm.). Bruce Hayward trapped at sites in the monument in 1965 and found four of the species that we found (California myotis, silver-haired bat, big brown bat, and hoary bat) and three species that we did not (long-eared myotis, Townsend's big-eared bat, and pallid bat) (Bruce J. Hayward in pers. comm. to Ronnie Sidner, 2001). As with his small mammal trapping effort, no other data or specimens exist from Hayward's effort at the monument. We found no bats at four netting sites and even on the most sampled site (WFGR6) the number of species captured ranged from zero to six per trapping event (Appendix L). These numbers reflect the difficulty of conducting an inventory of bats; the chance of catching them may be as much a function of luck as of proper net placement.

We did not record the Mexican gray wolf during our inventory work but the species is known to occur in the area as a result of a reintroduction effort by the U.S. Fish and Wildlife Service. Visitors to the area noted three separate sightings of wolves during the time of our inventory effort (visitor center reports, 20 April, 10 May, and 1 June 2002). One sighting (10 May) was along the West Fork of the Gila River within the West unit. We believe that two species have been extirpated from the area in and around Gila Cliff Dwellings NM: grizzly bear (Ursus arctos) and black-tailed prairie dog (Cynomys ludovicianus). The last grizzly bear in New Mexico is believed to have been killed in the early 1930s, and the monument is in the area "of probable extirpation" for the black-tailed prairie dog (Findley et al. 1975). 


\section{Chapter 7: Management Implications}

Based on the data from this study and our knowledge of the natural resource issues at the monument, herein we address issues that affect management of the monument's natural resources.

\section{Species Loss}

A comparison of our data to past work in the area indicates that species loss is confirmed to have occurred for the Chiricahua leopard frog, and species loss has probably occurred for three additional species of amphibian, one reptile, and three species of small mammals. In particular, we are concerned about the native aquatic vertebrate community given the abundance of non-native fishes (see Propst 2000), American bullfrogs, and crayfish in the West and Middle forks of the Gila River. The possible loss of so many native species should warn managers that the native aquatic vertebrate community, particularly along the Middle Fork of the Gila River, may have experienced a loss of species and declining populations. In keeping with the NPS mission of maintaining natural environments for future generations, we urge managers to study this system more closely and investigate the possible removal of non-native species (see next section).

\section{Managing Invasive, Non-native Species}

There are some non-native plants and one vertebrate that may pose significant threats to the natural resources of the monument and surrounding lands. Plants of concern include red brome, bufflegrass, and cheatgrass. The only non-native vertebrate that we found, the American bullfrog, appears to be very abundant and could pose a threat to many aquatic species, particularly native fishes (Minckley and Deacon 1991) and herpetofauna. It is beyond the scope of this project to review specific control techniques for each species, but a management plan for the eradication of these species, and early detection of new species should help guide future management decisions.

\section{Coordination with National Forest Managers}

Gila Cliff Dwellings NM is a small monument that is completely surrounded by the Gila Wilderness and other National Forest lands. The Heart Bar Ranch, administered by the New Mexico Game and Fish Department is located within a kilometer of the monument. The natural resource management of these larger pieces of land will continue to have enormous influence on the monuments' resources and it would be beneficial if land management actions at the monument were coordinated with staff at the Gila National Forest, in particular. The recent collaboration with USFS personnel for the monument's fire management plan (NPS 2003) is an excellent example of this type of cooperation.

\section{Natural Resources and Monument Staff}

Current staff at Gila Cliff Dwellings NM includes no natural resource professionals. Thus the monument lacks an efficient means of meeting the inventory, monitoring, and management needs related to maintaining biodiversity as described in this report. With present staffing, the monument will likely not be able to effectively (1) coordinate monitoring activities with the SDN Inventory and Monitoring program, (2) work with adjacent landowners to establish compatible land-use practices, (3) manage non-native species, and (4) coordinate research related to other natural resources management issues at the monument. Establishment of a Park Superintendent at Gila Cliff Dwellings NM in 2003 demonstrates NPS' commitment to the monument. Our inventory effort was hampered by our lack of understanding of the chain-of-command that was in place during the transition period between the monument's management by USFS personnel and that by the NPS. The current system of reporting to the monument superintendent will significantly improve the efficiency of future research at the monument. 


\section{Visitor Impacts}

Gila Cliff Dwellings NM and the surrounding area are experiencing an unprecedented increase in the number of visitors, presumably due to the area's cultural and natural treasures. Aside from the impacts that visitors may have on cultural resources (e.g., degradation of the cliff dwellings), we identify a few of the potential impacts to the plants and vertebrates of the area. As the number of visitors increases, so does the number of automobiles on the roads, which in turn leads to the dispersal and establishment of new species, particularly non-native plant species (Seabloom et al. 2003). Increased precipitation runoff from roads may contribute to this apparent pattern (i.e., seeds are more likely to germinate in areas receiving more moisture), and soils along the main access road to the monument are more likely to be disturbed (facilitating seed germination and plant establishment) than are soils in other parts of the monument. Increased vehicular traffic will also likely increase the mortality of terrestrial vertebrates or result in the modification of their behavior (Rosen and Lowe 1994, Trombulak and Frissell 2000, Cain et al. 2003). Visitors hiking the trails in the monument, particularly the trail to the cliff dwellings, may also affect wildlife movement patterns or cause direct mortality (see Chapter 2). 


\section{Chapter 8: Additional Inventories}

No inventory is ever truly complete; species distributions expand and contract across boundaries, particularly at small park units such as Gila Cliff Dwellings NM. In general, we feel that we have succeeded in balancing our efforts between qualitative surveys designed to detect the maximum number of species with quantitative, repeatable surveys designed to estimate relative abundance with an associated measure of precision. Additional inventories could reach the $90 \%$ completion mark for some taxonomic groups. Given the small size of the monument, however, any study that investigates the monument's resources should be undertaken in the context of the larger landscape, as we did for amphibians and reptiles and for all groups through incidental observations. This approach, which places the natural resources in the monument into a larger spatial context, puts monument staff in a stronger position to maintain, enhance, or selectively eliminate natural resources from the monument and the surrounding areas.

In addition to completing more field work, we also advocate searching natural history collections for specimens that were collected from the area. Most major collections have digitized (or are in the process of digitizing) their databases, thereby making it easy to extract location information. This task may best be accomplished by Sonoran Desert Inventory and Monitoring personnel, who would be interested in obtaining this information for all network park units.

\section{Plants}

Additional general botanizing surveys, carried out again during a season of above-average monsoon rains, should increase the species list for annual plants and may possibly detect species that were not recorded by our field crews but were found by others (species in University of Texas-El Paso collection; Appendix A). We suggest that future surveys target areas where non-native plants are likely to become established, such as along the main access road.

Great care was taken when we identified and accessioned plants into the University of
Arizona Herbarium and we are fairly certain of the correct identification of our specimens. We recommend a project to inspect specimens in the UTEP collection to confirm their correct identification and update their taxonomy (e.g., Halvorson 2003). Finally, use of modular plots placed throughout the monument would be an effective tool for monitoring long-term vegetation changes (see Powell et al. 2005a).

\section{Amphibians and Reptiles}

As outlined in Chapter 4, there are a number of amphibian species that we did not find, but were observed by Hayward and Hunt (1972). We recommend additional, targeted surveys for these species on lands adjacent to the monument, particularly on the Heart Bar Ranch, and preferably farther afield to determine if the absence of these amphibians is a regional phenomenon. We also recommend targeted surveys for Sonoran mud turtles.

An effective way to increase the species list for amphibians and reptiles is to take highquality photographs of animals as they are seen. The collection of road-killed animals, particularly snakes and toads, from along the main access road will likely add species to the monument's list. Other inventory efforts in Sonoran Desert Network parks have benefited from collection of these indisputable forms of evidence (Don Swann, pers. comm.).

\section{Birds}

Additional surveys during the winter season and during the spring and fall migrations will pick up species missed by efforts at other times. It is important to note, however, that bird lists are difficult to complete because birds are highly mobile. Only sites that are visited regularly by avid bird watchers (e.g., Bosque del Apache National Wildlife Refuge in southern New Mexico) have bird lists that can be considered to be "complete." 


\section{Mammals}

The use of ultrasonic detectors to identify bat species is increasing, and many researchers are helping to refine these field techniques and improve the technology (e.g., Johnson et al. 2002, Gannon et al. 2003). This tool may aid in detecting those species for which additional netting would be cost prohibitive.

We recommend additional small-mammal trapping on and near the TJ Ruins unit to search for the three species of rodents that were found there by Hayward and Hunt (1972) but not by our effort. The absence of these species would mean a loss of species for the monument, but more work needs to be conducted before reaching this conclusion.
Further Trailmaster camera work will document the presence of additional medium and large terrestrial mammals (e.g., bobcat). Camera operation and maintenance are fairly simple and rewarding tasks for technically proficient staff members or volunteers. Care should be taken in determining where to place camera units because of the potential for cameras to be damaged (as happened to one of our cameras in Cliff Dweller Canyon in 2002) or stolen. Finally, we recommend an effort to obtain sightings or reports of porcupine and American badger from the area; these species may be extirpated and local residents may have information about them. 


\section{Chapter 9: Literature Cited}

American Ornithologists' Union (AOU). 1998. Checklist of North American birds, seventh edition. American Ornithologists' Union and Allen Press Inc., Lawrence, KS.

American Ornithologists' Union (AOU). 2003. Fortysecond supplement to the American Ornithologists' Union checklist of North American birds. Auk 117:847-858.

Anderson, D. R. 2001. The need to get the basics right in wildlife field studies. Wildlife Society Bulletin 29:1294-1297

Averill-Murray, A., S. Lynn, and M. L. Morrison. 1999. Cowbird parasitism of Arizona Bell's vireos (Vireo bellii arizonae) in a desert riparian landscape: implications for cowbird management and riparian restoration. Studies in Avian Biology 18:109-120.

Baker, R. J., L. C. Bradley, R. D. Bradley, J. W. Dragoo, M. D. Engstrom, R. S. Hoffmann, C. A. Jones, F. Reid, D. W. Rice, and C. Jones. 2003. Revised checklist of North American mammals north of Mexico, 2003. Occasional Papers of the Museum of Texas Tech University 229:1-23.

Beauvais, G. P., and S. W. Buskirk. 1999. Modifying estimates of sampling effort to account for sprung traps. Wildlife Society Bulletin 27:39-43.

Bibby, C. J., N. D. Burgess, and D. A. Hill. 2002. Bird census techniques. Academic Press, London, England.

Biota Information System of New Mexico (BISON). 2004. Administered by Natural Heritage New Mexico, University of New Mexico, Albuquerque. Accessed September 16, 2004: http://nmnhp.unm. edu/bisonm/bisonquery.php

Buckland, S. T., D. R. Anderson, K. P. Burnham, J. L. Laake, D. L. Borchers, and L. Thomas. 2001. Introduction to distance sampling: estimating abundance of biological populations. Oxford University Press, New York.

Cain, A. T., V. R. Touvila, D. G. Hewitt, and M. E. Tewes. 2003. Effects of a highway and mitigation projects on bobcats in southern Texas. Biological Conservation 114:189-197.

Cole, C. J., and H. C. Dessauer. 1994. Unisexual lizards (genus Cnemidophorus) of the Madrean Archipelago. Pp. 267-273. In Biodiversity and management of the Madrean Archipelago: the Sky Islands of Southwestern United States and northwestern Mexico. General Technical Report
RM-GTR-264. USDA Forest Service, Rocky Mountain Research Station, Ft. Collins, CO.

Coleman, J. S., and S. A. Temple. 1993. Rural residents' free-ranging domestic cats: a survey. Wildlife Society Bulletin 21:381-390.

Colver, K. J., D. Stokes, and L. Stokes. 1999. Stokes field guide to bird songs. Time Warner, New York, NY.

Corn, S. P. 1994. Straight-line drift fences and pitfall traps. Pp. 109-117. In W. R. Heyer, M. A. Donnelly, R. W. McDiarmid, L. C. Hayek, and M. S. Foster, editors. Measuring and monitoring biodiversity: standard methods for amphibians. Smithsonian Institution Press, Washington, D.C.

Coulston, J. W., K. H. Ritters, and G. C. Smith. 2004. A preliminary assessment of the Montréal Process indicators of air pollution for the United States. Environmental Monitoring and Assessment 95:5774.

Crump, M. L., and N. J. Scott. 1994. Visual encounter surveys. Pp. 84-92. In W. R. Heyer, M. A. Donnelly, R. W. McDiarmid, L. C. Hayek, and M. S. Foster, editors. Measuring and monitoring biodiversity: standard methods for amphibians. Smithsonian Institution Press, Washington, D.C.

Cutler, T. L., and D. E. Swann. 1999. Using remote photography in wildlife ecology: a review. Wildlife Society Bulletin 27:571-581.

Davis, K., and W. L. Halvorson. 2000. A study plan to inventory vascular plants and vertebrates: Sonoran Desert Network. National Park Service, Phoenix, AZ.

Degenhardt, W. G., C. W. Painter, and A. H. Price. 1996. Amphibians and reptiles of New Mexico. University of New Mexico Press, Albuquerque, NM.

Dick-Peddie, W. A. 1993. New Mexico vegetation, past, present, and future. University of New Mexico Press, Albuquerque, NM.

Donovan, T. M., F. R. Thompson, J. Faaborg, and J. R. Probst. 1995. Reproductive success of migratory birds in habitat sources and sinks. Conservation Biology 9:1380-1395.

Ehrlich, P. R., D. S. Dobkin, and D. Wheye. 1988. The birder's handbook: a field guide to the natural history of North American birds. Simon and Shuster, New York, NY. 
Farnsworth, G. L., K. H. Pollock, J. D. Nichols, T. R. Simons, T. R. Hines, and J. E. Sauer. 2002. A removal model for estimating detection probabilities from point-count surveys. Auk 119:414-425.

Fernandez, P. J., and P. C. Rosen. 1996. Final report: effects of the introduced crayfish Orconectes virilis on native aquatic herpetofauna in Arizona. Submitted to Arizona Game and Fish Department, Heritage Fund, Phoenix, AZ.

Findley, J. S., A. H. Harris, D. E. Wilson, and C. Jones. 1975. Mammals of New Mexico. University of New Mexico Press, Albuquerque, NM.

Fuller, M. R., and J. A. Mosher. 1987. Raptor survey techniques. Pp. 37-66. In B. A. Geron-Pendleton, B. A. Millsap, K. W. Cline, and D. M. Bird, editors. Raptor management techniques manual. National Wildlife Federation, Washington, D.C.

Gannon, W. L., R. E. Sherwin, and S. Haymond. 2003. On the importance of articulating assumptions when conducting acoustic studies of habitat use by bats. Wildlife Society Bulletin 31:45-61.

Gibbons, J. M., and R. D. Semlitsch. 1981. Terrestrial drift fence with pitfall traps: an effective technique for quantitative sampling of animal populations. Brimleyana 7:1-6.

Halvorson, W. L. 2003. Verification of plant specimens from Sonoran Desert parks. Report to the Desert Southwest Cooperative Ecosystem Studies Unit, University of Arizona, Tucson, AZ.

Hayek, L. C., and M. A. Buzas. 1997. Surveying natural populations. Columbia University Press, New York, NY.

Hayes, M. P., and M. R. Jennings. 1986. Decline of Ranid frog species in western North America: are bullfrogs (Rana catesbeiana) responsible? Journal of Herpetology 20:490-509.

Hayward, B. J., and D. L. Hunt, Jr. 1972. Vertebrate survey of the Wilderness Ranger District, Gila National Forest, New Mexico. Unpublished report to the U.S. Forest Service, Silver City, NM.

Heilbrun, R. D., N. J. Silvy, M. E. Tewes, and M. J. Peterson. 2003. Using automatically triggered cameras to identify individual bobcats. Wildlife Society Bulletin 31:748-755.

Hockin, D., M. Ounsted, M. Gorman, D. Hill, V. Keller, and M. A. Barker. 1992. Examination of the effects of disturbance on birds with reference to its importance in ecological assessments. Journal of Environmental Management 36:253-286.

Hoffmeister, D. F. 1986. Mammals of Arizona. The University of Arizona Press, Tucson, AZ.
Hubbard, J. A., T. M. Mau-Crimmins, B. F. Powell, E. W. Albrecht, N. Chambers, and L. Carder. 2003. National Park Service Sonoran Desert Network monitoring plan: phase II. Sonoran Desert Network, Tucson, AZ.

Integrated Taxonomic Information System (ITIS). 2004. Accessed on 20 March 2004 from: http:// www.itis.usda.gov/index.html.

Ivanyi, C., J. Perry, T. R. Van Devender, and H. Lawler. 2000. Reptile and amphibian accounts. Pp. 533585. In S. J. Phillips and P. W. Comus, editors. A natural history of the Sonoran Desert. ArizonaSonora Desert Museum Press, Tucson, AZ.

Johnson, J. B., M. A. Menzel, J. W. Edwards, and W. M. Ford. 2002. A comparison of 2 acoustical bat survey techniques. Wildlife Society Bulletin 30:931-936.

Kiesecker, J. M., and A. R. Blaustein. 1997. Population differences in responses of red-legged frogs (Rana aurora) to introduced bullfrogs. Ecology 78:1752-1760.

Kupferberg, S. J. 1997. Bullfrog (Rana catesbeiana) invasion of a California river: the role of larval competition. Ecology 78:1736-1751

Krebs, C. J. 1998. Ecological methodology. Second edition. Addison-Welsey Educational, Menlo Park, CA.

Kucera, T. E., and R. H. Barrett. 1993. The Trailmaster camera system for detecting wildlife. Wildlife Society Bulletin 21:505-508.

Lancia, R. A., J. D. Nichols, and K. H. Pollock. 1996. Estimating the number of animals in wildlife populations. Pages 215-253. In T. A. Bookhout, editor. Research and management techniques for wildlife and habitats. Allen Press, Lawrence, KS.

Lawler, S. P., D. Dritz, T. Strange, and M. Holyoak. 1999. Effects of introduced mosquitofish and bullfrogs on the threatened California red-legged frog. Conservation Biology 13:613-622.

Lee, L. C., T. A. Muir, and R. R. Johnson. 1989. Riparian ecosystems as essential habitat for raptors in the American West. Pp. 15-26. In B. G. Pendleton, editor. Western raptor management symposium and workshop. National Wildlife Federation, Washington, D.C.

Luz, G. A., and J. B. Smith. 1976. Reactions of pronghorn antelope to helicopter overflight. Journal of Acoustical Society of America 59:15141515 .

MacArthur, R. H., and J. W. MacArthur. 1961. On bird species diversity. Ecology 42:594-598. 
Maestas, J. D., R. L. Knight, and W. C. Gilbert. 2003. Biodiversity across a rural land-use gradient. Conservation Biology 17:1425-1434.

Mehlman, D. W. 1995. Notes on the increase of the brown-headed cowbird in New Mexico. Western Birds 23:59-63.

Minckley, W. L., and J. E. Deacon, editors. 1991. Battle against extinction: native fish management in the American West. University of Arizona Press, Tucson, AZ.

National Park Service (NPS). 1987. Resource management plan. Gila Cliff Dwellings National Monument, New Mexico.

National Park Service (NPS). 1992. NPS-75: Natural resources inventory and monitoring guidelines. U.S. Dept. of Interior, Washington, D.C.

National Park Service (NPS). 1994. Report on effects of aircraft overflights on the National Park system. Report to Congress. Prepared pursuant to Public Law 100-91, The National Parks Overflights Act of 1987.

National Park Service (NPS). 2003. Fire management plan and environmental assessment. Gila Cliff Dwellings National Monument, New Mexico. U.S. Dept. of Interior, Washington, D.C.

National Park Service (NPS). 2004. NPS visitation database reports. Accessed on 11 August 2004. http://www2.nature.nps.gov/NPstats/npstats.cfm.

Nelson, L., and F. W. Clark. 1973. Correction for sprung traps in catch/effort calculations of trapping results. Journal of Mammology 54:295-298.

North American Ornithological Atlas Committee (NAOAC). 1990. Handbook for atlasing North American breeding birds. C. Smith, editor. Accessed 13 July 2001 from: http://americanbirding. org/norac/atlascont.htm.

Ohmart, R. D. 1994. The effects of human-induced changes on the avifauna of western riparian habitats. Studies in Avian Biology 15:272-285.

Painter, C. W. 1985. Herpetology of the Gila and San Francisco river drainages of southwestern New Mexico. Unpublished report to New Mexico Game and Fish Department, Albequerque, NM.

Powell, B. F., E. W. Albrecht, W. L. Halvorson, and K. Docherty. 2003. Biological inventory report for the Sonoran Desert Network: 2002. Annual Report No. 2. Sonoran Desert Network Inventory Program. U.S. Geological Survey, Sonoran Desert Field Station and School of Natural Resources, University of Arizona, Tucson, AZ.
Powell, B. F., E. W. Albrecht, W. L. Halvorson, C. A. Schmidt, P. Anning, and K. Docherty. 2005a. Vascular plant and vertebrate inventory of Tumacácori National Historical Park. USGS Open-File report 2005-1142. U.S. Geological Survey, Southwest Biological Science Center, Sonoran Desert Research Station, University of Arizona, Tucson, AZ.

Powell, B. F., E. W. Albrecht, W. L. Halvorson, C. A. Schmidt, and K. Docherty. 2005b. Vascular plant and vertebrate inventory of Gila Cliff Dwelling National Monument. Final report to the National Park Service, Sonoran Desert Inventory and Monitoring Program, Tucson, AZ.

Powell, B. F., K. Docherty, and W. L. Halvorson. 2002. Biological inventory report for the Sonoran Desert Network: 2000 and 2001 field seasons. Annual Report No. 1. Sonoran Desert Network Inventory Program. U.S. Geological Survey, Sonoran Desert Field Station and School of Natural Resources, University of Arizona, Tucson, AZ.

Powell, B. F., and R. J. Steidl. 2000. Nesting habitat and reproductive success of southwestern riparian birds. Condor 102:823-831.

Price, M. V. 1978. The role of microhabitat in structuring desert rodent communities. Ecology 59:10-921.

Propst, D. L. 2000. Systematic investigations of warmwater fish communities. Unpublished report FW-17-RD-27.

Propst, D. L., and K. R. Bestgen. 1991. Habitat and biology of the loach minnow, Tiaroga cabitis, in New Mexico. Copeia 1:29-38.

Propst, D. L., R. D. Larson, and A. L. Hobbes. 1998. Interactions of nonnative salmonids and native cyprids in the Gila River Drainage. Unpublished report. Federal Aid Project E-35.

Pulliam, H. R. 1988. Sources, sinks, and population regulation. American Naturalist 132:652-661.

Ralph, C. J., J. R. Sauer, S. Droege, technical editors. 1995. Monitoring bird populations by point counts. Gen. Tech. Rep. PSW-GTR-149. Pacific Southwest Research Station, Forest Service, U.S. Department of Agriculture, Albany, CA.

Rappole, J. H. 1995. The ecology of migrant birds: a neotropical perspective. Smithsonian Institution Press, Washington, D.C.

Reynolds, R. T., J. M. Scott, and R. A. Nussbaum. 1980. A variable circular-plot method for estimating bird numbers. Condor 82:309-313. 
Rice, J., B. W. Anderson, and R. D. Ohmart. 1984. Comparison of the importance of different habitat attributes to avian community organization. Journal of Wildlife Management 48:895-911.

Rieman, B., and J. Clayton. 1997. Wildlife and native fish: issues of forest health and conservation of sensitive species. Fisheries 22:6-15.

Rosen, P. C., and C. H. Lowe. 1994. Highway mortality of snakes in the Sonoran desert of southern Arizona. Biological Conservation 68:143-148.

Rothstein, S. I. 1994. The cowbird's invasion of the far west: history, causes, and consequences experienced by host species. Studies in Avian Biology 15: 301-315.

Russell, P. 1992. Gila Cliff Dwellings National Monument: an administrative history. Southwest Cultural Resources Center. Professional Papers No. 46. Southwest Region Division of History, Santa Fe, NM.

Schwalbe, C. R., and P. C. Rosen. 1988. Preliminary report on effects of bullfrogs on wetland herpetofauna in southeastern Arizona. Pp. 166-173. In R. C. Szaro, K. E. Severson, and D. R. Patton, editors. Management of amphibians, reptiles, and small mammals in North America. Gen. Tech. Rep. RM-166, U.S. Department of Agriculture, Forest Service, Rocky Mountain Research Station, Fort Collins, CO.

Schweitzer, S. H., D. M. Finch, and D. M. Leslie, Jr. 1998. The brown-headed cowbird and its riparian dependent hosts in New Mexico. General Technical Report RMRS-GTR-1. U.S. Department of Agriculture, Forest Service, Rocky Mountain Research Station, Fort Collins, CO.

Seabloom, E. W., E. T. Borer, V. L. Boucher, R. S. Burton, K. L. Cottingham, L. Goldwasser, W. K. Gram, B. E. Kendall, and F. Micheli. 2003. Competition, seed limitation, disturbance, and reestablishment of California native annual forbs. Ecological Applications 13:575-592.

Sivinski, R., and K. Lightfoot. 1992. Inventory of rare and endangered plants of New Mexico. New Mexico Forestry and Resources Conservation Division Energy, Minerals and Natural Resources Department. Santa Fe, NM.

Skagen, S. K., C. P. Melcher, W. H. Howe, and F. L. Knopf. 1998. Comparative use of riparian corridors and oases by migrating birds in southeastern Arizona. Conservation Biology 12:896-909.
Sprouse, T., R. Emanuel, and B. Tellman. 2002. Final report: surface water quality monitoring overview and assessment for the Sonoran Desert Network, National Park Service. Unpublished report. Water Resources Research Center, University of Arizona, Tucson, AZ.

Sredl, M. J., P. C. Rosen, and G. A. Bradley. 2000. Chytrid fungus widespread in Arizona. Annual meeting for the American Society for Ichthyologists and Herpetologists, La Paz, Mexico.

Stamp, N. E., and R. D. Ohmart. 1979. Rodents of desert shrub and riparian woodland habitats of the Sonoran Desert. Southwestern Naturalist 24:279-289.

Stebbins, R. C. 2003. A field guide to western reptiles and amphibians. Third edition. Houghton Mifflin, New York, NY.

Stohlgren, T. J., J. F. Quinn, M. Ruggiero, and G. S. Waggoner. 1995. Status of biotic inventories in U.S. national parks. Biological Conservation 71:97-106.

Strong, T. R., and C. E. Bock. 1990. Bird species distribution in riparian habitats in southeastern Arizona. Condor 92:866-885.

Sureda, M., and M. L. Morrison. 1999. Habitat characteristics of small mammals in southeastern Utah. Great Basin Naturalist 59:323-330.

Swann, D. E., C. C. Hass, D. C. Dalton, and S. A. Wolf. 2004. Infrared-triggered cameras for detecting wildlife: an evaluation and review. Wildlife Society Bulletin 32:1-9.

Swarthout, E. C. H., and R. J. Steidl. 2003. Experimental effects of hiking on breeding Mexican spotted owls. Conservation Biology 17:307-315.

Theobald, D. M., J. R. Miller, and N. T. Hobbs. 1997. Estimating the cumulative effects of development on wildlife habitat. Landscape and Urban Planning 39:25-36.

Thompson, S. K. 1992. Sampling. John Wiley and Sons, New York, NY.

Trombulak, S. C., and C. A. Frissell. 2000. Review of ecological effects of roads on terrestrial and aquatic communities. Conservation Biology 14:18-30.

United States Department of Agriculture (USDA). 2004. The PLANTS Database, Version 3.5. National Plant Data Center, Natural Resources Conservation Service, Baton Rouge, LA. Accessed on 15 July 2004 from: http://plants.usda. gov. 
United States Forest Service (USFS). 2003. Geology of the Gila Cliff Dwellings. Gila National Forest Wilderness Ranger District. United States Department of Agriculture, Silver City, NM.

Verner, J., and L. V. Ritter. 1983. A comparison of transects and point counts in oak-pine woodlands of California. Condor 87:47-68.

Weisenberger, M. E., P. R. Krausman, M. C. Wallace, D. W. DeYoung, and O. E. Maughan. 1996. Effects of simulated jet aircraft noise on heart rate and behavior of desert ungulates. Journal of Wildlife Management 60:52-61.

Western Regional Climate Center (WRCC). 2004. New Mexico climate summaries from Gila Hot Springs, New Mexico. Accessed on 13 June 2004 from: http://www.wrcc.dri.edu/summary/ climsmnm.html

White, G. C., K. P. Anderson, K. P. Burnham, and D. L. Otis. 1983. Capture-recapture and removal methods for sampling closed populations. Los Alamos National Laboratory, Los Alamos, NM.

Williams, O. F. 1995. A survey of rodents in the Gila Wilderness Area in recently burned habitats of the type preferred by Mexican spotted owls. Unpublished report to Gila National Forest, Silver City, NM.

Wright, J. W., and L. J. Vitt. 1993. Biology of the whiptail lizards (genus Cnemidophorus). Oklahoma Museum of Natural History, Norman, OK.

Zimmerman, D. A. 1995. Birds of the Gila National Forest: a checklist. Prepared by the USDA Forest Service in cooperation with the Southwest New Mexico Audubon Society. 

Appendix A. Plant species that were observed or documented at Gila Cliff Dwellings NM by University of
Arizona Inventory personnel (UA) 2001-2003 or by specimens located at the University of Texas-EI Paso (UTEP) herbarium. Species in bold-faced type are non-native (USDA 2004).

\begin{tabular}{|c|c|c|c|c|}
\hline Family & Scientific name & Common name & UA & UTEP \\
\hline Aceraceae & Acer negundo L. & boxelder & $\mathrm{X}$ & $\mathrm{X}$ \\
\hline Agavaceae & Yucca baccata Torr. & banana yucca & $\mathrm{X}$ & \\
\hline \multirow[t]{4}{*}{ Amaranthaceae } & Amaranthus palmeri S. Wats. & carelessweed & $\mathrm{X}$ & $\mathrm{X}$ \\
\hline & Gomphrena caespitosa Torr. & tufted globe amaranth & $\mathrm{X}$ & $\mathrm{X}$ \\
\hline & Gomphrena sonorae Torr. & Sonoran globe amaranth & $\mathrm{X}$ & \\
\hline & Tidestromia lanuginosa (Nutt.) Standl.. & woolly tidestromia & $\mathrm{X}$ & \\
\hline \multirow[t]{3}{*}{ Anacardiaceae } & Rhus aromatica Ait. & fragrant sumac & & $\mathrm{X}$ \\
\hline & Rhus trilobata var. trilobata Nutt. & skunkbush sumac & $\mathrm{X}$ & \\
\hline & Toxicodendron pubescens P. Mill. & Atlantic poison oak & $\mathrm{X}$ & \\
\hline \multirow[t]{2}{*}{ Apiaceae } & Cicuta douglasii (DC.) Coult. \& Rose & western water hemlock & $\mathrm{X}$ & \\
\hline & Pseudocymopterus montanus (Gray) Coult. \& Rose & alpine false springparsley & $X$ & $\mathrm{X}$ \\
\hline Apocynaceae & Apocynum cannabinum L. & Indianhemp & & $\mathrm{X}$ \\
\hline \multirow[t]{4}{*}{ Asclepiadaceae } & Asclepias macrotis Torr. & longhood milkweed & $\mathrm{X}$ & \\
\hline & Asclepias nyctaginifolia Gray & Mojave milkweed & $X$ & \\
\hline & Asclepias subverticillata (Gray) Vail & horsetail milkweed & & $\mathrm{X}$ \\
\hline & Asclepias tuberosa L. & butterfly milkweed & $X^{a}$ & $\mathrm{X}$ \\
\hline \multirow[t]{39}{*}{ Asteraceae } & Achillea millefolium $\mathrm{L}$. & common yarrow & $\mathbf{X}$ & $\mathbf{x}$ \\
\hline & Ageratina herbacea (Gray) King \& H.E. Robins.. & fragrant snakeroot & $X$ & $\mathrm{X}$ \\
\hline & Ageratina rothrockii (Gray) King \& H.E. Robins. & Rothrock's snakeroot & & $x$ \\
\hline & Antennaria microphylla Rydb. & littleleaf pussytoes & $X$ & \\
\hline & Antennaria parvifolia Nutt. & small-leaf pussytoes & $X$ & \\
\hline & Artemisia carruthii Wood ex Carruth. & Carruth's sagewort & $X$ & \\
\hline & Artemisia dracunculus L. & tarragon & $X$ & \\
\hline & Artemisia ludoviciana Nutt. & white sagebrush & $\mathrm{X}$ & $\mathrm{X}$ \\
\hline & Baccharis pteronioides DC. & yerba de pasmo & $\mathrm{X}$ & \\
\hline & Bahia dissecta (Gray) Britt. & ragleaf bahia & $\mathrm{X}$ & $x$ \\
\hline & Bidens bigelovii Gray & Bigelow's beggarticks & $X$ & $\mathrm{X}$ \\
\hline & Bidens pilosa L. & hairy beggarticks & $\mathbf{X}$ & \\
\hline & Brickellia brachyphylla (Gray) Gray & plumed brickellbush & $\mathrm{X}$ & \\
\hline & $\begin{array}{l}\text { Brickellia eupatorioides var. chlorolepis (Woot. \& Standl.) B.L. } \\
\text { Turner }\end{array}$ & false boneset & $X$ & \\
\hline & Brickellia floribunda Gray & Chihuahuan brickellbush & $X$ & $\mathrm{X}$ \\
\hline & Brickellia rusbyi Gray & stinking brickellbush & & $\mathrm{X}$ \\
\hline & Carminatia tenuiflora DC. & plumeweed & $\mathrm{X}$ & \\
\hline & Chaenactis douglasii (Hook.) Hook. \& Arn. & Douglas' dustymaiden & $X$ & \\
\hline & Chaetopappa ericoides (Torr.) Nesom & rose heath & $\mathrm{X}$ & $\mathrm{X}$ \\
\hline & Cirsium grahamii Gray & Graham's thistle & $\mathrm{X}$ & \\
\hline & Cirsium neomexicanum Gray & New Mexico thistle & $\mathrm{X}$ & $x$ \\
\hline & Conyza canadensis (L.) Cronq. & Canadian horseweed & $X$ & $\mathrm{x}$ \\
\hline & Cosmos parviflorus (Jacq.) Pers. & southwestern cosmos & $\mathrm{X}$ & \\
\hline & $\begin{array}{l}\text { Ericameria nauseosa var. nauseosa (Pallas ex Pursh) Nesom } \\
\text { \& Baird }\end{array}$ & rubber rabbitbrush & $X$ & $X$ \\
\hline & Erigeron arizonicus Gray & Arizona fleabane & $X$ & \\
\hline & Erigeron colomexicanus A. Nels. & running fleabane & & $\mathrm{X}$ \\
\hline & Erigeron divergens Torr. \& Gray & spreading fleabane & $X$ & \\
\hline & Erigeron formosissimus Greene & beautiful fleabane & & X \\
\hline & Erigeron formosissimus var formosissimus Greene & beautiful fleabane & $X$ & \\
\hline & Erigeron neomexicanus Gray & New Mexico fleabane & & $\mathrm{X}$ \\
\hline & Erigeron oreophilus Greenm. & chaparral fleabane & $X$ & $\mathrm{x}$ \\
\hline & Erigeron speciosus (Lindl.) DC... & aspen fleabane & $X$ & \\
\hline & Erigeron vreelandii Greene & Vreeland's erigeron & $X$ & \\
\hline & Eurybia glauca (Nutt.) Nesom & gray aster & & $\mathrm{X}$ \\
\hline & Gaillardia pinnatifida Torr. & red dome blanketflower & $\mathrm{X}$ & $\mathrm{X}$ \\
\hline & Gaillardia pulchella Foug. & firewheel & $X$ & $\mathrm{X}$ \\
\hline & Gnaphalium sp. L. & cudweed & $X$ & \\
\hline & Gutierrezia microcephala (DC.) Gray & threadleaf snakeweed & $\mathrm{X}$ & $\mathrm{X}$ \\
\hline & Helianthus annuus L. & common sunflower & $X$ & $X$ \\
\hline
\end{tabular}




\begin{tabular}{|c|c|c|c|c|}
\hline Family & Scientific name & Common name & $\overline{U A}$ & UTEP \\
\hline & Heliomeris longifolia var. Iongifolia (Robins. \& Greenm.) & & \multirow{3}{*}{$X$} & \\
\hline \multirow[t]{48}{*}{ Asteraceae } & Cockerell & longleaf false goldeneye & & $\mathrm{X}$ \\
\hline & Heliomeris multiflora Nutt. & showy goldeneye & & $\mathrm{X}$ \\
\hline & Heterosperma pinnatum Cav. & wingpetal & $\mathrm{X}$ & \\
\hline & Hieracium fendleri var. fendleri Schultz-Bip. & yellow hawkweed & $\mathrm{X}$ & \\
\hline & Hymenoclea monogyra Torr. \& Gray ex Gray & singlewhorl burrobrush & $\mathrm{X}$ & \\
\hline & Hymenopappus artemisiifolius DC. & oldplainsman & \multirow[b]{2}{*}{$X$} & $\mathrm{X}$ \\
\hline & Hymenopappus mexicanus Gray & Mexican woollywhite & & \\
\hline & Hymenothrix wislizeni Gray & TransPecos thimblehead & $x$ & \\
\hline & Hymenothrix wrightii Gray & Wright's thimblehead & \multirow{2}{*}{$\begin{array}{l}X \\
X\end{array}$} & $\mathrm{X}$ \\
\hline & Lactuca graminifolia Michx. & grassleaf lettuce & & \\
\hline & Lactuca serriola L. & prickly lettuce & \multirow[t]{2}{*}{$\mathbf{X}^{\mathrm{a}}$} & \\
\hline & Machaeranthera bigelovii (Gray) Greene & Bigelow's tansyaster & & $\mathrm{X}$ \\
\hline & Machaeranthera gracilis (Nutt.) Shinners & slender goldenweed & $\mathrm{X}$ & $\mathrm{X}$ \\
\hline & Malacothrix fendleri Gray & Fendler's desertdandelion & $\mathrm{X}$ & $\mathrm{X}$ \\
\hline & Melampodium sericeum Lag. & rough blackfoot & $\mathbf{X}$ & \\
\hline & $\begin{array}{l}\text { Packera neomexicana var. neomexicana (Gray) W.A. Weber \& } \\
\text { A. Löve }\end{array}$ & New Mexico groundsel & \multirow[t]{3}{*}{$X$} & $x$ \\
\hline & Packera plattensis (Nutt.) W.A. Weber \& A. Love & prairie groundsel & & $\mathrm{X}$ \\
\hline & Packera tridenticulata (Rydb.) W.A. Weber \& A Love & threetooth ragwort & & $\mathrm{X}$ \\
\hline & Pectis filipes Harvey \& Gray & fivebract cinchweed & \multirow{4}{*}{$\begin{array}{l}X \\
X \\
X\end{array}$} & $\mathrm{X}$ \\
\hline & Pericome caudata Gray & mountain tail-leaf & & \\
\hline & Pseudognaphalium canescens (DC.) W.A. Weber & Wright's cudweed & & \\
\hline & $\begin{array}{l}\text { Pseudognaphalium canescens ssp. canescens (DC.) W.A. } \\
\text { Weber }\end{array}$ & Wright's cudweed & & $\mathrm{X}$ \\
\hline & Pseudognaphalium stramineum (Kunth) W.A. Weber & cottonbatting plant & \multirow[b]{2}{*}{$x$} & $\mathrm{X}$ \\
\hline & Psilactis asteroides Gray & New Mexico tansyaster & & $\mathrm{X}$ \\
\hline & Rudbeckia laciniata L. & cutleaf coneflower & $\mathrm{X}$ & $\mathrm{X}$ \\
\hline & Sanvitalia abertii Gray & Abert's creeping zinnia & \multirow{2}{*}{$x$} & \\
\hline & Senecio arizonicus Greene & Arizona ragwort & & \\
\hline & Senecio flaccidus Less. & threadleaf ragwort & $\mathrm{X}$ & $\mathrm{X}$ \\
\hline & Senecio flaccidus var. flaccidus Less. & threadleaf ragwort & \multirow[t]{2}{*}{$\mathrm{X}$} & \\
\hline & $\begin{array}{l}\text { Senecio flaccidus var. monoensis (Greene) B.L. Turner \& T.M. } \\
\text { Barkl. }\end{array}$ & Mono ragwort & & \\
\hline & $\begin{array}{l}\text { Senecio spartioides var. multicapitatus (Greenm. ex Rydb.) } \\
\text { Welsh }\end{array}$ & broomlike ragwort & $X$ & $\mathrm{X}$ \\
\hline & Solidago wrightii Gray & Wright's goldenrod & \multirow[b]{2}{*}{$\mathrm{X}$} & $\mathrm{X}$ \\
\hline & Solidago wrightii var. wrightii Gray & Wright's goldenrod & & \\
\hline & Sonchus asper (L.) Hill & spiny sowthistle & \multirow{2}{*}{$\begin{array}{l}X \\
X\end{array}$} & \\
\hline & Stephanomeria pauciflora (Torr.) A. Nels. & brownplume wirelettuce & & \\
\hline & Stephanomeria thurberi Gray & Thurber's wirelettuce & \multirow[t]{2}{*}{$X^{a}$} & \\
\hline & Symphyotrichum ascendens (Lindl.) Nesom & western aster & & $\mathrm{X}$ \\
\hline & $\begin{array}{l}\text { Symphyotrichum falcatum var. commutatum (Torr. \& Gray) } \\
\text { Nesom }\end{array}$ & white prairie aster & & 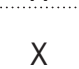 \\
\hline & Symphyotrichum lanceolatum (Willd.) Nesom var. hesperium & white panicle aster & & $\mathrm{X}$ \\
\hline & Symphyotrichum praealtum var. praealtum (Poir.) Nesom & willowleaf aster & & $\mathrm{X}$ \\
\hline & Taraxacum laevigatum (Willd.) DC. & rock dandelion & $\mathbf{X}$ & $x$ \\
\hline & Taraxacum officinale G.H. Weber ex Wiggers & common dandelion & $\mathrm{X}$ & \\
\hline & Townsendia excapa (Richards.) T. Porter & & $\mathrm{X}$ & \\
\hline & Tragopogon dubius Scop. & yellow salsify & $\mathrm{X}$ & \\
\hline & Tragopogon pratensis $\mathrm{L}$. & Jack-go-to-bed-at-noon & & $\mathrm{X}$ \\
\hline & Verbesina encelioides (Cav.) Benth. \& Hook. f. ex Gray & golden crownbeard & $\mathrm{X}$ & $X$ \\
\hline & Viguiera cordifolia Gray & heartleaf goldeneye & & $X$ \\
\hline & Viguiera dentata (Cav.) Spreng. & toothleaf goldeneye & $\mathrm{X}$ & \\
\hline Betulaceae & Alnus oblongifolia Torr. & Arizona alder & $X$ & $X$ \\
\hline Boraginaceae & Cryptantha cinerea (Greene) Crong. var. cinerea & James' cryptantha & $X^{a}$ & \\
\hline & Cryptantha cinerea var. jamesii Cronq. & James' cryptantha & & $\mathrm{X}$ \\
\hline & Cryptantha stricta (Osterhout) Payson & Yampa River cryptantha & $\mathrm{X}$ & \\
\hline & Hackelia floribunda (Lehm.) I.M. Johnston & manyflower stickseed & & $\mathrm{X}$ \\
\hline & Hackelia pinetorum (Greene ex Gray) I.M. Johnston & Livermore stickseed & $\mathrm{X}$ & \\
\hline & Hackelia ursina (Greene ex Gray) I.M. Johnston & Chiuahuan stickseed & & X \\
\hline & Lappula occidentalis (S. Wats.) Greene & flatspine stickseed & $\mathrm{X}$ & \\
\hline & Lappula occidentalis var. cupulata (Gray) Higgins & flatspine stickseed & $X$ & \\
\hline
\end{tabular}




\begin{tabular}{|c|c|c|c|c|}
\hline Family & Scientific name & Common name & UA & UTEP \\
\hline \multirow[t]{5}{*}{ Borignaceae } & Lappula occidentalis var. occidentalis (S. Wats.) Greene & flatspine stickseed & & $\mathrm{X}$ \\
\hline & Lithospermum incisum Lehm. & narrowleaf stoneseed & $\mathrm{X}$ & $\mathrm{X}$ \\
\hline & Lithospermum multiflorum Torr. ex Gray & manyflowered stoneseed & $\mathrm{X}$ & $\mathrm{X}$ \\
\hline & Macromeria viridiflora DC. & giant-trumpets & $X$ & \\
\hline & Mertensia franciscana Heller & Franciscan bluebells & $\mathrm{X}$ & \\
\hline \multirow[t]{24}{*}{ Brassicaceae } & Arabis fendleri (S. Wats.) Greene & Fendler's rockcress & $X$ & \\
\hline & Barbarea orthoceras Ledeb. & American yellowrocket & $\mathrm{X}$ & \\
\hline & Descurainia incana ssp incana (Bernh. ex Fisch. \& C.A. Mey.) & mountain tansymustard & & $X$ \\
\hline & Descurainia obtusa (Greene) O.E. Schulz & blunt tansymustard & & $\mathrm{X}$ \\
\hline & Descurainia obtusa ssp. adenophora (Woot. \& Standl.) Detling & blunt tansymustard & $\mathrm{X}$ & \\
\hline & Descurainia obtusa ssp. obtusa (Greene) O.E. Schulz & blunt tansymustard & $\mathrm{X}$ & \\
\hline & Descurainia sophia (L.) Webb ex Prantl & herb sophia & $\mathbf{X}$ & \\
\hline & Draba crassifolia Graham & snowbed draba & $\mathrm{X}$ & \\
\hline & Draba cuneifolia Nutt. ex Torr. \& Gray & wedgeleaf draba & $\mathrm{X}$ & $\mathrm{X}$ \\
\hline & Draba mogollonica Greene & Mongollon Mountain draba & & $\mathrm{X}$ \\
\hline & Erysimum capitatum (Dougl. ex Hook.) Greene & sanddune wallflower & $\mathrm{X}$ & $\mathrm{X}$ \\
\hline & Lepidium lasiocarpum Nutt. & shaggyfruit pepperweed & $\mathrm{X}$ & \\
\hline & Lepidium thurberi Woot. & Thurber's pepperweed & $\mathrm{X}$ & \\
\hline & Lepidium virginicum $\mathrm{L}$...... & Virginia pepperweed & & $\mathrm{X}$ \\
\hline & Lepidium virginicum var. medium (Greene) C.L. Hitchc. & medium pepperweed & $\mathrm{X}$ & \\
\hline & Lesquerella aurea Woot. & golden bladderpod & & $\mathrm{X}$ \\
\hline & Lesquerella gooddingii Rollins \& Shaw & Goodding's bladderpod & $\mathrm{X}$ & \\
\hline & Lesquerella gordonii (Gray) S. Wats. & Gordon's bladderpod & $\mathrm{X}$ & \\
\hline & Lesquerella intermedia (S. Wats.) Heller & mid bladderpod & & $\mathrm{X}$ \\
\hline & Rorippa nasturtium-aquaticum (L.) Hayek & watercress & $\mathrm{X}$ & $\mathrm{X}$ \\
\hline & Schoenocrambe linearifolia (Gray) Rollins & slimleaf plainsmustard & $\mathrm{X}$ & $\mathrm{X}$ \\
\hline & Sisymbrium altissimum L. & tall tumblemustard & $\mathbf{X}$ & \\
\hline & Thlaspi montanum var. fendleri (Gray) P. Holmgren & Fendler's pennycress & & $\mathrm{X}$ \\
\hline & Thlaspi montanum var. montanum L. & alpine pennycress & $\mathrm{X}$ & \\
\hline \multirow[t]{6}{*}{ Cactaceae } & Echinocereus fendleri (Engelm.) F. Seitz & pinkflower hedgehog cactus & $\mathrm{X}$ & \\
\hline & Echinocereus triglochidiatus Engelm. & kingcup cactus & $\mathrm{X}$ & \\
\hline & Escobaria vivipara var. vivipara (Nutt.) Buxbaum & spinystar & $\mathrm{X}$ & \\
\hline & Opuntia macrorhiza Engelm. & twistspine pricklypear & $\mathrm{X}$ & \\
\hline & Opuntia phaeacantha Engelm. & tulip pricklypear & $X$ & \\
\hline & Opuntia spinosior (Engelm.) Toumey & walkingstick cactus & $X$ & \\
\hline Callitrichaceae & Callitriche heterophylla Pursh & twoheaded water-starwort & $\mathrm{X}$ & \\
\hline Campanulaceae & Triodanis perfoliata (L.) Nieuwl. & clasping Venus' looking-glass & $\mathrm{X}$ & \\
\hline Cannabinaceae & Humulus lupulus var. neomexicanus A. Nels. \& Cockerell & common hop & $\mathrm{X}$ & \\
\hline \multirow[t]{3}{*}{ Capparaceae } & Cleome serrulata Pursh & Rocky Mountain beeplant & $\mathrm{X}$ & $\mathrm{X}$ \\
\hline & Polanisia dodecandra (L.) DC. & redwhisker clammyweed & $\mathrm{X}$ & $\mathrm{X}$ \\
\hline & Polanisia dodecandra ssp. trachysperma (Torr. \& Gray) Iltis & sandyseed clammyweed & & $\mathrm{X}$ \\
\hline Caprifoliaceae & Lonicera albiflora Torr. \& Gray & western white honeysuckle & $\mathrm{X}$ & $\mathrm{X}$ \\
\hline \multirow[t]{5}{*}{ Caryophyllaceae } & Cerastium brachypodum (Engelm. ex Gray) B.L. Robins. & shortstalk chickweed & $X$ & \\
\hline & Cerastium glomeratum Thuill. & sticky chickweed & $\mathrm{X}$ & \\
\hline & Drymaria glandulosa K. Presl & Fendler's drymary & $\mathrm{X}$ & \\
\hline & Silene antirrhina $\mathrm{L}$. & sleepy silene & $\mathrm{X}$ & \\
\hline & Silene laciniata Cav. & cardinal catchfly & $X$ & $X$ \\
\hline \multirow[t]{4}{*}{ Chenopodiaceae } & Atriplex canescens (Pursh) Nutt. & fourwing saltbush & $\mathrm{X}$ & $X$ \\
\hline & Chenopodium fremontii S. Wats. & Fremont's goosefoot & & $\mathrm{X}$ \\
\hline & Chenopodium glaucum $\mathrm{L}$. & oakleaf goosefoot & $\mathrm{X}$ & \\
\hline & Chenopodium graveolens Willd. & fetid goosefoot & $\mathrm{X}$ & \\
\hline Clusiaceae & Hypericum formosum H.B.K. & & $X$ & \\
\hline \multirow[t]{2}{*}{ Commelinaceae } & Commelina dianthifolia Delile & birdbill dayflower & $\mathrm{X}$ & \\
\hline & Tradescantia pinetorum Greene & pinewoods spiderwort & X & \\
\hline \multirow[t]{4}{*}{ Convolvulaceae } & Evolvulus sericeus var. sericeus Sw. & silver dwarf morning-glory & $\mathrm{X}$ & \\
\hline & Ipomoea capillacea (Kunth) G. Don & purple morning-glory & $\mathrm{X}$ & \\
\hline & Ipomoea costellata Torr. & crestrib morning-glory & $\mathrm{X}$ & \\
\hline & Ipomoea purpurea (L.) Roth & tall morning-glory & $\mathrm{X}$ & \\
\hline Cornaceae & Cornus sericea ssp. sericea L. & redosier dogwood & $\mathrm{X}$ & \\
\hline \multirow[t]{2}{*}{ Crassulaceae } & Sedum cockerellii Britt. & Cockerell's stonecrop & $\mathrm{X}$ & $\mathrm{X}$ \\
\hline & Sedum wrightii Gray & Wright's stonecrop & $\mathrm{X}$ & \\
\hline Cucurbitaceae & Cucurbita foetidissima Kunth & Missouri gourd & $\mathrm{X}$ & $\mathrm{X}$ \\
\hline
\end{tabular}




\begin{tabular}{|c|c|c|c|c|}
\hline \multirow{3}{*}{$\begin{array}{l}\text { Family } \\
\text { Cucurbitaceae }\end{array}$} & Scientific name & Common name & $\mathrm{UA}$ & UTEP \\
\hline & Echinopepon wrightii (Gray) S. Wats. & wild balsam apple & $\mathrm{X}$ & \\
\hline & Sicyos ampelophyllus Woot. \& Standl. & streamside burr cucumber & & $\mathrm{X}$ \\
\hline \multirow[t]{4}{*}{ Cupressaceae } & Cupressus arizonica Greene & Arizona cypress & $\mathrm{X}$ & \\
\hline & Juniperus deppeana Steud. & alligator juniper & $\mathrm{X}$ & \\
\hline & Juniperus osteosperma (Torr.) Little & Utah juniper & $\mathrm{x}$ & \\
\hline & Juniperus scopulorum Sarg. & Rocky Mountain juniper & $\mathrm{x}$ & \\
\hline \multirow[t]{8}{*}{ Cyperaceae } & Carex lenticularis var. lipocarpa (Holm) L.A. Standley & Kellogg's sedge & $\mathrm{x}$ & \\
\hline & Carex occidentalis Bailey & western sedge & $\mathrm{x}$ & \\
\hline & Carex praegracilis W. Boott & clustered field sedge & & $\mathrm{X}$ \\
\hline & Carex vallicola Dewey & valley sedge & $\mathrm{X}$ & \\
\hline & Cyperus sp. L. & flatsedge & $\mathrm{X}$ & \\
\hline & Eleocharis montevidensis Kunth & sand spikerush & $\mathrm{x}$ & \\
\hline & Eleocharis palustris (L.) Roemer \& J.A. Schultes & common spikerush & & $\mathrm{X}$ \\
\hline & Eleocharis parishii Britt. & Parish's spikerush & $\mathrm{x}$ & \\
\hline \multirow[t]{3}{*}{ Equisetaceae } & Equisetum arvense L. & field horsetail & $\mathrm{X}$ & $\mathrm{X}$ \\
\hline & Equisetum hyemale L. & scouringrush horsetail & & $\mathrm{x}$ \\
\hline & Equisetum laevigatum A. Braun & smooth horsetail & $\mathrm{x}$ & $\mathrm{X}$ \\
\hline \multirow[t]{10}{*}{ Euphorbiaceae } & Chamaesyce albomarginata (Torr. \& Gray) Small & whitemargin sandmat & $\mathrm{X}$ & $\mathrm{X}$ \\
\hline & Chamaesyce serpyllifolia ssp. serpyllifolia (Pers.) Small & thymeleaf sandmat & $\mathrm{X}$ & \\
\hline & Euphorbia bilobata Engelm. & blackseed spurge & $\mathrm{x}$ & \\
\hline & Euphorbia brachycera Engelm. & horned spurge & $\mathrm{x}$ & \\
\hline & Euphorbia chamaesula Boiss. & mountain spurge & & $\mathrm{X}$ \\
\hline & Euphorbia exstipulata Engelm. & squareseed spurge & & $\mathrm{x}$ \\
\hline & Euphorbia heterophylla L. & Mexican fireplant & $\mathrm{x}$ & \\
\hline & Jatropha cardiophylla (Torr.) Muell.-Arg. & sangre de cristo & $\mathrm{x}$ & \\
\hline & Tragia nepetifolia Cav. & catnip noseburn & $\mathrm{x}$ & \\
\hline & Tragia ramosa Torr. & branched noseburn & $\mathrm{x}$ & $\mathrm{X}$ \\
\hline \multirow[t]{32}{*}{ Fabaceae } & Astragalus crassicarpus Nutt. & groundplum milkvetch & $\mathrm{X}$ & \\
\hline & Astragalus tephrodes Gray & ashen milkvetch & $\mathrm{X}$ & \\
\hline & Calliandra humilis Benth. & dwarf stickpea & $\mathrm{x}$ & \\
\hline & Cologania angustifolia Kunth & longleaf cologania & $\mathrm{x}$ & \\
\hline & Dalea albiflora Gray & whiteflower prairie clover & $\mathrm{x}$ & $\mathrm{X}$ \\
\hline & Dalea candida Michx. ex Willd. & white prairie clover & $x^{a}$ & \\
\hline & Dalea candida var. oligophylla (Torr.) Shinners & white prairie clover & & $\mathrm{X}$ \\
\hline & Dalea filiformis Gray & Sonoran prairie clover & $\mathrm{x}$ & \\
\hline & Dalea urceolata Greene & pineforest prairie clover & $\mathrm{x}$ & \\
\hline & Desmodium grahamii Gray & Graham's ticktrefoil & $\mathrm{x}$ & \\
\hline & Desmodium neomexicanum Gray & New Mexico ticktrefoil & $\mathrm{x}$ & \\
\hline & Desmodium procumbens (P. Mill.) A.S. Hitchc. & western trailing ticktrefoil & $\mathrm{x}$ & \\
\hline & Lathyrus graminifolius (S. Wats.) White & grassleaf pea & $\mathrm{x}$ & \\
\hline & Lathyrus lanszwertii var. leucanthus (Rydb.) Dorn & Nevada pea & $\mathrm{x}$ & $\mathrm{X}$ \\
\hline & Lotus wrightii (Gray) Greene & Wright's deervetch & $X^{a}$ & $\mathrm{X}$ \\
\hline & Lupinus argenteus Pursh & silvery lupine & $\mathrm{X}$ & \\
\hline & Lupinus brevicaulis S. Wats. & shortstem lupine & $\mathrm{x}$ & $\mathrm{X}$ \\
\hline & Lupinus hillii Greene & Hill's lupine & $\mathrm{x}$ & \\
\hline & Macroptilium gibbosifolium (Ortega) A. Delgado & variableleaf bushbean & $\mathrm{X}$ & \\
\hline & Medicago lupulina L. & black medick & & $x$ \\
\hline & Melilotus alba Medikus & white sweetclover & & $x$ \\
\hline & Melilotus indica (L.) All. & sourclover & $\mathrm{x}$ & \\
\hline & Melilotus officinalis (L.) Lam. & yellow sweetclover & $\mathrm{x}$ & $\mathrm{x}$ \\
\hline & Parkinsonia microphylla Torr. & yellow paloverde & $x$ & \\
\hline & Phaseolus acutifolius Gray & tepary bean & $\mathrm{x}$ & \\
\hline & Phaseolus angustissimus Gray & slimleaf bean & $X^{a}$ & $\mathrm{X}$ \\
\hline & Psoralidium tenuiflorum (Pursh) Rydb. & slimflower scurfpea & & $\mathrm{X}$ \\
\hline & Rhynchosia senna Gillies ex Hook. & Texas snoutbean & $\mathrm{X}$ & $\mathrm{x}$ \\
\hline & Robinia neomexicana Gray & New Mexico locust & $\mathrm{X}$ & $X$ \\
\hline & Trifolium wormskioldii Lehm. & cows clover & $\mathrm{x}$ & \\
\hline & Vicia americana Muhl. ex Willd. & American vetch & $\mathrm{X}$ & $\mathrm{x}$ \\
\hline & Vicia leucophaea Greene & Mogollon Mountain vetch & $\mathrm{x}$ & \\
\hline \multirow[t]{3}{*}{ Fagaceae } & Quercus arizonica Sarg. & Arizona white oak & $\mathrm{x}$ & $\mathrm{X}$ \\
\hline & Quercus gambelii Nutt. & Gambel oak & $\mathrm{x}$ & $\mathrm{x}$ \\
\hline & Quercus grisea Liebm.. & gray oak & $\mathrm{x}$ & $\mathrm{x}$ \\
\hline
\end{tabular}




\begin{tabular}{|c|c|c|c|c|}
\hline Family & Scientific name & Common name & $\overline{U A}$ & UTEP \\
\hline Fumariaceae & Corydalis aurea Willd. & scrambled eggs & $\mathrm{X}$ & $\mathrm{X}$ \\
\hline Garryaceae & Garrya wrightii Torr. & Wright's silktassel & $\mathrm{X}$ & \\
\hline Gentianaceae & Frasera speciosa Dougl. ex Griseb. & elkweed & $\mathrm{X}$ & $\mathrm{X}$ \\
\hline \multirow[t]{3}{*}{ Geraniaceae } & Erodium cicutarium (L.) L'Hér. ex Ait. & redstem stork's bill & $\mathbf{x}$ & \\
\hline & Geranium caespitosum James & pineywoods geranium & $\mathrm{X}$ & $\mathrm{X}$ \\
\hline & Geranium richardsonii Fisch. \& Trautv. & Richardson's geranium & $\mathrm{X}$ & $\mathrm{X}$ \\
\hline \multirow[t]{3}{*}{ Grossulariaceae } & Ribes aureum Pursh & golden currant & $\mathrm{X}$ & \\
\hline & Ribes cereum Dougl. & wax currant & $\mathrm{X}$ & \\
\hline & Ribes leptanthum Gray & trumpet gooseberry & $\mathrm{X}$ & $\mathrm{X}$ \\
\hline \multirow[t]{3}{*}{ Hydrophyllaceae } & Nama dichotomum (Ruiz \& Pavón) Choisy & wishbone fiddleleaf & $\mathrm{X}$ & \\
\hline & Phacelia caerulea Greene & skyblue phacelia & $\mathrm{X}$ & $\mathrm{X}$ \\
\hline & Phacelia heterophylla Pursh & varileaf phacelia & $\mathrm{X}$ & $X$ \\
\hline \multirow[t]{2}{*}{ Juglandaceae } & Juglans major (Torr.) Heller & Arizona walnut & $\mathrm{X}$ & $\mathrm{X}$ \\
\hline & Juglans microcarpa Berl. & little walnut & & $\mathrm{X}$ \\
\hline Juncaceae & Luzula sp. DC. & woodrush & $\mathrm{X}$ & \\
\hline \multirow[t]{10}{*}{ Lamiaceae } & Agastache pallidiflora (Heller) Rydb. & Bill Williams Mountain giant hyssop & $X$ & $\mathrm{x}$ \\
\hline & Dracocephalum parviflorum Nutt. & American dragonhead & $X$ & \\
\hline & Hedeoma nana (Torr.) Briq. & dwarf false pennyroyal & $\mathrm{X}$ & \\
\hline & Hedeoma oblongifolia (Gray) Heller & oblongleaf false pennyroyal & $\mathrm{X}$ & $\mathrm{X}$ \\
\hline & Marrubium vulgare $\mathrm{L}$. & horehound & $\mathbf{X}$ & $\mathbf{X}$ \\
\hline & Mentha arvensis L. & wild mint & $\mathrm{X}$ & $\mathrm{X}$ \\
\hline & Monarda fistulosa $\mathrm{L}$. & wild bergamot & & $\mathrm{X}$ \\
\hline & Monarda fistulosa var. menthifolia (Graham) Fern. & wild bergamot & $\mathrm{X}$ & \\
\hline & Salvia reflexa Hornem. & lanceleaf sage & $\mathrm{X}$ & $\mathrm{X}$ \\
\hline & Salvia subincisa Benth. & sawtooth sage & $\mathrm{X}$ & \\
\hline \multirow[t]{7}{*}{ Liliaceae } & Allium cernuum var. obtusum Cockerell ex J.F. Macbr. & nodding onion & $\mathrm{X}$ & \\
\hline & Allium macropetalum Rydb. & largeflower onion & $\mathrm{X}$ & \\
\hline & Echeandia flavescens (J.A. \& J.H. Schultes) Cruden & Torrey's craglily & $X$ & \\
\hline & Maianthemum racemosum (L.) Link & feathery false lily of the valley & & $\mathrm{X}$ \\
\hline & Maianthemum racemosum ssp. amplexicaule (Nutt.) LaFrankie & feathery false lily of the valley & $\mathrm{X}$ & \\
\hline & Maianthemum stellatum (L.) Link & starry false lily of the valley & $\mathrm{X}$ & \\
\hline & Polygonatum cobrense (Woot. \& Standl.) R.R. Gates & McKittrick's Solomon's seal & & $X$ \\
\hline Linaceae & Linum neomexicanum Greene & New Mexico yellow flax & $\mathrm{X}$ & \\
\hline \multirow[t]{2}{*}{ Loasaceae } & Mentzelia albicaulis (Dougl. ex Hook.) Dougl. ex Torr. \& Gray & whitestem blazingstar & $\mathrm{X}$ & \\
\hline & Mentzelia pumila Nutt. ex Torr. \& Gray & dwarf mentzelia & $\mathrm{X}$ & \\
\hline \multirow[t]{2}{*}{ Malvaceae } & Anoda cristata (L.) Schlecht. & crested anoda & $\mathrm{X}$ & \\
\hline & Sphaeralcea fendleri Gray & Fendler's globemallow & $X$ & $x$ \\
\hline \multirow[t]{2}{*}{ Monotropaceae } & Monotropa hypopithys L. & pinesap & & $X^{a}$ \\
\hline & Pterospora andromedea Nutt. & woodland pinedrops & & $X^{a}$ \\
\hline \multirow[t]{9}{*}{ Nyctaginaceae } & Boerhavia coccinea P. Mill. & scarlet spiderling & $\mathrm{X}$ & $\mathrm{X}$ \\
\hline & Boerhavia purpurascens Gray & purple spiderling & $\mathrm{X}$ & \\
\hline & Mirabilis albida (Walt.) Heimerl & white four o'clock & $\mathrm{X}$ & \\
\hline & Mirabilis coccinea (Torr.) Benth. \& Hook. f. & scarlet four o'clock & $\mathrm{X}$ & $x$ \\
\hline & Mirabilis linearis (Pursh) Heimerl & narrowleaf four o'clock & $\mathrm{X}$ & \\
\hline & Mirabilis longiflora L. & sweet four o'clock & $\mathrm{X}$ & $\mathrm{X}$ \\
\hline & Mirabilis multiflora (Torr.) Gray & Colorado four o'clock & $\mathrm{X}$ & $\mathrm{X}$ \\
\hline & Mirabilis oxybaphoides (Gray) Gray & smooth spreading four o'clock & $\mathrm{X}$ & $x$ \\
\hline & Mirabilis pumila (Standl.) Standl. & dwarf four o'clock & $\mathrm{X}$ & \\
\hline \multirow[t]{3}{*}{ Oleaceae } & Forestiera pubescens var pubescens Nutt. & stretchberry & $\mathrm{X}$ & $\mathrm{X}$ \\
\hline & Fraxinus velutina Torr. & velvet ash & $X$ & $\mathrm{X}$ \\
\hline & Menodora scabra Gray & rough menodora & $\mathrm{X}$ & $\mathrm{X}$ \\
\hline \multirow[t]{9}{*}{ Onagraceae } & Epilobium ciliatum Raf. & fringed willowherb & $\mathrm{X}$ & \\
\hline & Gaura coccinea Nutt. ex Pursh & scarlet beeblossom & $\mathrm{X}$ & \\
\hline & $\begin{array}{l}\text { Gaura hexandra ssp. gracilis (Woot. \& Standl.) Raven \& } \\
\text { Gregory }\end{array}$ & harlequinbush & $X$ & $X$ \\
\hline & Gaura mollis James & velvetweed & $X^{a}$ & \\
\hline & Oenothera albicaulis Pursh & whitest evening-primrose & $X$ & \\
\hline & Oenothera caespitosa Nutt. & tufted evening-primrose & $\mathrm{X}$ & $x$ \\
\hline & Oenothera caespitosa ssp. caespitosa Nutt. & tufted evening-primrose & $X$ & \\
\hline & $\begin{array}{l}\text { Oenothera elata ssp. hookeri (Torr. \& Gray) W. Dietr. \& W.L. } \\
\text { Wagner }\end{array}$ & Hooker's evening-primrose & $X^{a}$ & \\
\hline & Oenothera neomexicana (Small) Munz & New Mexico evening-primrose & $\mathrm{X}$ & \\
\hline
\end{tabular}




\begin{tabular}{|c|c|c|c|c|}
\hline Family & Scientific name & Common name & UA & UTEP \\
\hline \multirow{3}{*}{ Orchidaceae } & Malaxis macrostachya (Lex.) Kuntze & Chiricahua adder's-mouth orchid & & $X^{a}$ \\
\hline & Malaxis wendtii Salazar & Wendt's adder's-mouth orchid & & $X^{a}$ \\
\hline & Platanthera sparsiflora (S. Wats.) Schlechter var. sparsiflora & sparse-flowered bog orchid & & $X^{a}$ \\
\hline \multirow[t]{4}{*}{ Oxalidaceae } & Oxalis alpina (Rose) Rose ex R. Knuth & alpine woodsorrel & $\mathrm{X}$ & \\
\hline & Oxalis corniculata $\mathrm{L}$. & creeping woodsorrel & $\mathrm{X}$ & \\
\hline & Oxalis decaphylla Kunth & tenleaf woodsorrel & $\mathrm{X}$ & \\
\hline & Oxalis drummondii Gray & Drummond's woodsorrel & $X^{a}$ & \\
\hline Papaveraceae & Argemone pleiacantha Greene & southwestern pricklypoppy & $\mathrm{X}$ & \\
\hline Parmeliaceae & Usnea arizonica Mot. & Arizona beard lichen & $\mathrm{X}$ & \\
\hline \multirow[t]{5}{*}{ Pinaceae } & Abies lasiocarpa (Hook.) Nutt. & subalpine fir & $\mathrm{X}$ & \\
\hline & Pinus cembroides Zucc. & Mexican pinyon & $\mathrm{X}$ & $X^{a}$ \\
\hline & Pinus edulis Engelm. & twoneedle pinyon & $\mathrm{X}$ & \\
\hline & Pinus ponderosa P.\& C. Lawson & ponderosa pine & $\mathrm{X}$ & \\
\hline & Pseudotsuga menziesii (Mirbel) Franco & Douglas-fir & $\mathrm{X}$ & \\
\hline Plantaginaceae & Plantago major L. & common plantain & & $\mathrm{X}$ \\
\hline \multirow[t]{46}{*}{ Poaceae } & Agrostis gigantea Roth & redtop & & $\mathrm{x}$ \\
\hline & Agrostis scabra Willd. & rough bentgrass & $x$ & \\
\hline & Alopecurus aequalis Sobol. & shortawn foxtail & $\mathrm{X}$ & \\
\hline & Aristida purpurea var fendleriana (Steud.) Vasey & Fendler's threeawn & $\mathrm{X}$ & \\
\hline & Aristida purpurea var. longiseta (Steud.) Vasey & Fendler threeawn & $\mathrm{X}$ & \\
\hline & Aristida ternipes var. gentilis (Henr.) Allred & spidergrass & $x$ & \\
\hline & Bothriochloa barbinodis (Lag.) Herter & cane bluestem & $\mathrm{X}$ & \\
\hline & Bothriochloa springfieldii (Gould) Parodi & Springfield's beardgrass & & $\mathrm{X}$ \\
\hline & Bouteloua curtipendula (Michx.) Torr. & sideoats grama & $\mathrm{X}$ & $\mathrm{X}$ \\
\hline & Bouteloua eriopoda (Torr.) Torr. & black grama & $x$ & \\
\hline & Bouteloua gracilis (Willd. ex Kunth) Lag. ex Griffiths & blue grama & $\mathrm{X}$ & $\mathrm{X}$ \\
\hline & Bouteloua hirsuta Lag. & hairy grama & $x$ & \\
\hline & Bouteloua radicosa (Fourn.) Griffiths & purple grama & $\mathrm{X}$ & \\
\hline & Bromus anomalus Rupr. ex Fourn. & nodding brome & $X$ & \\
\hline & Bromus carinatus Hook. \& Arn. & California brome & & $\mathrm{X}$ \\
\hline & Bromus frondosus (Shear) Woot. \& Standl. & weeping brome & & $\mathrm{x}$ \\
\hline & Bromus hordeaceus L. & soft brome & $\mathbf{x}$ & \\
\hline & Bromus inermis Leyss. & smooth brome & $\mathbf{x}$ & $\mathrm{X}$ \\
\hline & Bromus japonicus Thunb. ex Murr. & Japanese brome & $x$ & \\
\hline & Bromus kalmii Gray & arctic brome & & $\mathrm{X}$ \\
\hline & Bromus rubens $\mathrm{L}$. & red brome & $x$ & \\
\hline & Bromus tectorum $\mathrm{L}$. & cheatgrass & $\mathrm{X}$ & \\
\hline & Chloris virgata Sw. & feather fingergrass & $X^{a}$ & \\
\hline & Dasyochloa pulchella (Kunth) Willd. ex Rydb. & low woollygrass & $\mathrm{X}$ & \\
\hline & Echinochloa crus-galli (L.) Beauv. & barnyardgrass & $\mathrm{X}$ & $\mathrm{X}$ \\
\hline & Elymus arizonicus (Scribn. \& J.G. Sm.) Gould & Arizona wheatgrass & $X$ & \\
\hline & Elymus canadensis L. & Canada wildrye & $X$ & $\mathrm{X}$ \\
\hline & Elymus elymoides (Raf.) Swezey & squirreltail & $X$ & $\mathrm{X}$ \\
\hline & Eragrostis curvula (Schrad.) Nees & weeping lovegrass & $x$ & \\
\hline & Eragrostis mexicana (Hornem.) Link & Mexican lovegrass & $\mathrm{X}$ & \\
\hline & Glyceria striata (Lam.) A.S. Hitchc. & fowl mannagrass & $\mathrm{X}$ & \\
\hline & Hesperostipa neomexicana (Thurb. ex Coult.) Barkworth & New Mexico feathergrass & $X$ & \\
\hline & Koeleria macrantha (Ledeb.) J.A. Schultes & prairie Junegrass & $\mathrm{x}$ & \\
\hline & Leptochloa dubia (Kunth) Nees & green sprangletop & $\mathrm{X}$ & $\mathrm{X}$ \\
\hline & Leptochloa fascicularis var. fascicularis (Lam.) Gray & bearded sprangletop & $\mathrm{X}$ & \\
\hline & Lycurus setosus (Nutt.) C.G. Reeder & bristly wolfstail & $X$ & \\
\hline & Muhlenbergia emersleyi Vasey & bullgrass & & $\mathrm{X}$ \\
\hline & Muhlenbergia mexicana (L.) Trin. & Mexican muhly & $\mathrm{X}$ & \\
\hline & Muhlenbergia polycaulis Scribn. & cliff muhly & $X$ & \\
\hline & Muhlenbergia racemosa (Michx.) B.S.P. & marsh muhly & & $\mathrm{X}$ \\
\hline & Muhlenbergia repens (J. Presl) A.S. Hitchc. & creeping muhly & $\mathrm{X}$ & \\
\hline & Muhlenbergia rigens (Benth.) A.S. Hitchc. & deergrass & $X$ & \\
\hline & Muhlenbergia rigida (Kunth) Trin. & purple muhly & $\mathrm{X}$ & \\
\hline & Muhlenbergia sinuosa Swallen & marshland muhly & $X$ & \\
\hline & Panicum capillare L. & witchgrass & & $\mathrm{X}$ \\
\hline & Panicum hirticaule var. hirticaule J. Presl & Mexican panicgrass & $\mathrm{X}$ & \\
\hline
\end{tabular}




\begin{tabular}{|c|c|c|c|c|}
\hline Family & Scientific name & Common name & $\overline{U A}$ & UTEP \\
\hline \multirow[t]{11}{*}{ Poaceae } & Panicum obtusum Kunth & vine mesquite & $x$ & \\
\hline & Pascopyrum smithii (Rydb.) A. Löve & western wheatgrass & $\mathrm{X}$ & $\mathrm{X}$ \\
\hline & Pennisetum ciliare (L.) Link & buffelgrass & $\mathrm{x}$ & \\
\hline & Piptochaetium fimbriatum (Kunth) A.S. Hitchc. & pinyon ricegrass & $\mathrm{X}$ & \\
\hline & Poa fendleriana (Steud.) Vasey & muttongrass & $\mathrm{X}$ & $\mathrm{X}$ \\
\hline & Poa pratensis L. & Kentucky bluegrass & $\mathrm{X}$ & $\mathrm{X}$ \\
\hline & Schizachyrium cirratum (Hack.) Woot. \& Standl. & Texas bluestem & $\mathrm{X}$ & \\
\hline & Setaria grisebachii Fourn. & Grisebach's bristlegrass & $\mathrm{X}$ & \\
\hline & Sphenopholis obtusata (Michx.) Scribn. & prairie wedgescale & $X$ & \\
\hline & Sporobolus cryptandrus (Torr.) Gray & sand dropseed & $\mathrm{X}$ & \\
\hline & Vulpia octoflora (Walt.) Rydb. & sixweeks fescue & $\mathrm{X}$ & $\mathrm{X}$ \\
\hline \multirow[t]{9}{*}{ Polemoniaceae } & Gilia inconspicua (Sm.) Sweet & shy gilia & $\mathrm{X}$ & \\
\hline & Gilia mexicana A.\& V. Grant & El Paso gilia & $X$ & \\
\hline & Gilia sinuata Dougl. ex Benth. & rosy gilia & $X$ & \\
\hline & Ipomopsis aggregata (Pursh) V. Grant & scarlet gilia & $\mathrm{X}$ & \\
\hline & Ipomopsis macombii (Torr. ex Gray) V. Grant & Macomb's ipomopsis & & $\mathrm{X}$ \\
\hline & Linanthus nuttallii (Gray) Greene ex Milliken & Nuttall's linanthus & $\mathrm{X}$ & \\
\hline & Linanthus nuttalli (Gray) Greene ex Milliken ssp nuttallii & Nuttall's linanthus & & $\mathrm{X}$ \\
\hline & Phlox gracilis ssp. gracilis (Hook.) Greene & slender phlox & & $\mathrm{X}$ \\
\hline & Phlox longifolia Nutt. & longleaf phlox & & $\mathrm{X}$ \\
\hline \multirow[t]{2}{*}{ Polygalaceae } & Monnina wrightii Gray & blue pygmyflower & $\mathrm{X}$ & \\
\hline & Polygala obscura Benth............. & velvetseed milkwort & $\mathrm{X}$ & \\
\hline \multirow[t]{10}{*}{ Polygonaceae } & Eriogonum abertianum Torr. & Abert's buckwheat & $\mathrm{X}$ & $x$ \\
\hline & Eriogonum alatum Torr. & winged buckwheat & $\mathrm{X}$ & \\
\hline & Eriogonum pharnaceoides Torr. & wirestem buckwheat & $\mathrm{X}$ & $\mathrm{X}$ \\
\hline & Eriogonum polycladon Benth. & sorrel buckwheat & & $\mathrm{X}$ \\
\hline & Eriogonum wrightii Torr. ex Benth. & bastardsage & $\mathrm{X}$ & $\mathrm{x}$ \\
\hline & Polygonum convolvulus L. & black bindweed & $\mathrm{X}$ & \\
\hline & Polygonum lapathifolium L...... & curlytop knotweed & $\mathrm{X}$ & $X$ \\
\hline & Polygonum persicaria L.... & spotted ladysthumb & $\mathrm{X}$ & $\mathrm{X}$ \\
\hline & Rumex acetosella $\mathrm{L}$. & common sheep sorrel & $\mathbf{X}$ & \\
\hline & Rumex crispus L. & curly dock & & $\mathbf{X}$ \\
\hline Pontederiaceae & Heteranthera limosa (Sw.) Willd. & blue mudplantain & $X$ & \\
\hline \multirow{2}{*}{ Portulacaceae } & Portulaca oleracea L. & little hogweed & $\mathrm{X}$ & \\
\hline & Talinum pulchellum Woot. \& Standl. & showy fameflower & $\mathrm{X}$ & \\
\hline \multirow[t]{3}{*}{ Primulaceae } & Androsace occidentalis Pursh & western rockjasmine & $x$ & $\mathrm{X}$ \\
\hline & Androsace septentrionalis L. & pygmyflower rockjasmine & $\mathrm{X}$ & $\mathrm{X}$ \\
\hline & $\begin{array}{l}\text { Androsace septentrionalis ssp. puberulenta (Rydb.) G.T. } \\
\text { Robbins }\end{array}$ & pygmyflower rockjasmine & $\mathrm{X}$ & \\
\hline \multirow[t]{6}{*}{ Pteridaceae } & Bommeria hispida (Mett. ex Kuhn) Underwood & copper fern & $\mathrm{X}$ & \\
\hline & Dryopteris filix-mas (L.) Schott & male fern & $\mathrm{X}$ & \\
\hline & Pellaea atropurpurea (L.) Link & purple cliffbrake & $\mathrm{X}$ & \\
\hline & Pellaea wrightiana Hook. & Wright's cliffbrake & $\mathrm{X}$ & \\
\hline & Pteridium aquilinum (L.) Kuhn & western brackenfern & & $X^{a}$ \\
\hline & Selaginella underwoodii Hieron. & Underwood's spikemoss & $\mathrm{X}$ & \\
\hline \multirow[t]{7}{*}{ Ranunculaceae } & Aquilegia chrysantha Gray & golden columbine & $\mathrm{X}$ & $\mathrm{X}$ \\
\hline & Clematis ligusticifolia Nutt. & western white clematis & $X$ & $\mathrm{X}$ \\
\hline & Myosurus cupulatus S. Wats. & Arizona mousetail & $\mathrm{X}$ & \\
\hline & Ranunculus aquatilis L. & whitewater crowfoot & $\mathrm{X}$ & \\
\hline & Ranunculus hydrocharoides Gray & frogbit buttercup & $\mathrm{X}$ & \\
\hline & Ranunculus uncinatus D. Don ex G. Don & woodland buttercup & $\mathrm{X}$ & \\
\hline & Thalictrum fendleri Engelm. ex Gray & Fendler's meadow-rue & $\mathrm{X}$ & $\mathrm{X}$ \\
\hline Rhamnaceae & Frangula betulifolia ssp. betulifolia (Greene) V. Grub. & beechleaf frangula & $\mathrm{X}$ & $\mathrm{X}$ \\
\hline \multirow[t]{9}{*}{ Rosaceae } & Agrimonia striata Michx. & roadside agrimony & $\mathrm{X}$ & \\
\hline & Cercocarpus montanus Raf. & alderleaf mountain mahogany & $\mathrm{X}$ & \\
\hline & Cercocarpus montanus var. paucidentatus (S. Wats.) F.L & hairy mountain mahogany & & $\mathrm{X}$ \\
\hline & Fallugia paradoxa (D. Don) Endl. ex Torr. & Apache plume & $\mathrm{X}$ & $\mathrm{X}$ \\
\hline & Malus sp. P. Mill. & apple & $X$ & \\
\hline & Potentilla rivalis Nutt. & brook cinquefoil & $X$ & \\
\hline & Potentilla thurberi Gray & scarlet cinquefoil & $\mathrm{X}$ & \\
\hline & Prunus serotina var. virens (Woot. \& Standl.) McVaugh & black cherry & $\mathrm{X}$ & $\mathrm{X}$ \\
\hline & Purshia mexicana (D. Don) Henrickson & Mexican cliffrose & & $\mathrm{X}$ \\
\hline
\end{tabular}




\begin{tabular}{|c|c|c|c|c|}
\hline Family & Scientific name & Common name & UA & UTEP \\
\hline \multirow[t]{2}{*}{ Rosaceae } & Rosa woodsii Lindl. & Woods' rose & & $X$ \\
\hline & Rosa woodsii var. ultramontana (S. Wats.) Jepson & Woods' rose & $\mathrm{X}$ & \\
\hline \multirow[t]{6}{*}{ Rubiaceae } & Galium fendleri Gray & Fendler's bedstraw & $X$ & \\
\hline & Galium mexicanum Kunth & Mexican bedstraw & $\mathrm{X}$ & \\
\hline & Galium microphyllum Gray & bracted bedstraw & & $\mathrm{X}$ \\
\hline & Galium wrightii Gray & Wright's bedstraw & $X$ & $\mathrm{X}$ \\
\hline & Houstonia rosea (Raf.) Terrell & rose bluet & & $\mathrm{X}$ \\
\hline & Houstonia wrightii Gray & pygmy bluet & $\mathrm{X}$ & \\
\hline \multirow[t]{2}{*}{ Rutaceae } & Ptelea trifoliata L. & common hoptree & & $X$ \\
\hline & Ptelea trifoliata ssp. angustifolia (Benth.) V. Bailey & common hoptree & $\mathrm{X}$ & \\
\hline \multirow[t]{4}{*}{ Salicaceae } & Populus angustifolia James & narrowleaf cottonwood & $X$ & $x$ \\
\hline & Salix exigua Nutt. & narrowleaf willow & $X$ & $\mathrm{X}$ \\
\hline & Salix irrorata Anderss. & dewystem willow & & $\mathrm{X}$ \\
\hline & Salix taxifolia Kunth & yewleaf willow & $X$ & \\
\hline \multirow[t]{3}{*}{ Saxfragiaceae } & Fendlera wrightii (Gray) Heller & Wright's fendlerbush & $X$ & \\
\hline & Heuchera parviflora Bartl. & littleflower alumroot & $x$ & \\
\hline & Heuchera novomexicana Wheelock & New Mexico alumroot & $\mathrm{X}$ & \\
\hline \multirow[t]{11}{*}{ Scrophulariaceae } & Castilleja integra Gray & wholeleaf Indian paintbrush & $\mathrm{X}$ & $\mathrm{X}$ \\
\hline & Maurandella antirrhiniflora (Humb. \& Bonpl. ex Willd.) Rothm. & roving sailor & $\mathrm{X}$ & $\mathrm{X}$ \\
\hline & Mimulus glabratus Kunth & roundleaf monkeyflower & & $\mathrm{X}$ \\
\hline & Mimulus guttatus DC. & seep monkeyflower & $X$ & $\mathrm{X}$ \\
\hline & Mimulus rubellus Gray & little redstem monkeyflower & $X$ & \\
\hline & Penstemon barbatus (Cav.) Roth & beardlip penstemon & X & $x$ \\
\hline & Penstemon jamesii Benth. & James' beardtongue & $\mathrm{X}$ & \\
\hline & Penstemon virgatus Gray & upright blue beardtongue & $\mathrm{X}$ & $\mathrm{X}$ \\
\hline & Scrophularia parviflora Woot. \& Standl. & pineland figwort & $X$ & $X$ \\
\hline & Verbascum thapsus L. & common mullein & $x$ & \\
\hline & Veronica anagallis-aquatica L. & water speedwell & $\mathrm{X}$ & \\
\hline \multirow[t]{9}{*}{ Solanaceae } & Datura wrightii Regel & sacred thorn-apple & $\mathrm{X}$ & \\
\hline & Lycium pallidum Miers & pale desert-thorn & $\mathrm{X}$ & \\
\hline & Physalis hederifolia Gray & ivyleaf groundcherry & 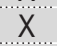 & $X$ \\
\hline & Solanum americanum P. Mill.. & American black nightshade & & $x$ \\
\hline & Solanum douglasii Dunal & greenspot nightshade & $\mathrm{X}$ & \\
\hline & Solanum elaeagnifolium Cav. & silverleaf nightshade & $\mathrm{X}$ & \\
\hline & Solanum fendleri Gray ex Torr. & Fendler's horsenettle & $\mathrm{X}$ & $x$ \\
\hline & Solanum heterodoxum Dunal & melonleaf nightshade & $\mathrm{X}$ & \\
\hline & Solanum jamesii Torr. & wild potato & $\mathrm{X}$ & \\
\hline Typhaceae & Typha latifolia L............ & broadleaf cattail & $\mathrm{X}$ & \\
\hline Ülmaceae & Celtis pallida Torr. & spiny hackberry & $\mathrm{X}$ & \\
\hline \multirow[t]{2}{*}{ Ürticaceae } & Parietaria pensylvanica Muhl. ex Willd. & Pennsylvania pellitory & $\mathrm{X}$ & \\
\hline & Urtica dioica $\mathrm{L}$. & stinging nettle & $\mathbf{x}$ & \\
\hline \multirow[t]{2}{*}{ Valerianaceae } & Valeriana arizonica Gray & Arizona valerian & $\mathrm{X}$ & $x$ \\
\hline & Valeriana edulis Nutt. ex Torr. \& Gray & tobacco root & & $\mathrm{X}$ \\
\hline \multirow[t]{3}{*}{ Verbenaceae } & Glandularia bipinnatifida (Nutt.) Nutt... & Dakota mock vervain & $X$ & \\
\hline & Verbena hastata L. & swamp verbena & $X^{a}$ & \\
\hline & Verbena neomexicana (Gray) Small & New Mexico vervain & $\mathrm{X}$ & \\
\hline \multirow[t]{2}{*}{ Violaceae } & Viola affinis Le Conte & sand violet & $\mathrm{X}$ & \\
\hline & Viola canadensis $\mathrm{L}$. & Canadian white violet & $\mathrm{X}$ & $\mathrm{X}$ \\
\hline & Phoradendron juniperinum Engelm ex Gray & juniper mistletoe & $\mathrm{X}$ & $\mathrm{X}$ \\
\hline \multirow[t]{2}{*}{ Vitaceae } & Parthenocissus quinquefolia (L.) Planch. & Virginia creeper & $\mathrm{X}$ & \\
\hline & Vitis arizonica Engelm. & canyon grape & $x$ & $X$ \\
\hline Zygophyllaceae & Kallstroemia parviflora J.B.S. Norton & warty caltrop & $\mathrm{X}$ & \\
\hline
\end{tabular}

a Found only outside of the monument boundary. 
Appendix B. Amphibian and reptile species observed, documented with photo voucher, or documented with specimen voucher by University of Arizona Inventory personnel, Gila Cliff Dwellings NM, 2001 and 2002. Species in bold-faced type is non-native. See Appendix $\mathrm{H}$ for additional information on vouchers.

\begin{tabular}{|c|c|c|c|c|c|c|}
\hline \multirow[b]{2}{*}{ Order } & \multirow[b]{2}{*}{ Family } & \multirow[b]{2}{*}{ Scientific name } & \multirow[b]{2}{*}{ Common name } & \multicolumn{3}{|c|}{ Documentation type } \\
\hline & & & & Observation & $\begin{array}{c}\text { Photo } \\
\text { voucher }\end{array}$ & $\begin{array}{c}\text { Specimen } \\
\text { voucher }\end{array}$ \\
\hline \multirow{3}{*}{ Anura } & Bufonidae & Bufo microscaphus & Arizona toad ${ }^{a}$ & $X$ & $x$ & $X$ \\
\hline & Hylidae & Hyla arenicolor & canyon treefrog & $\mathrm{X}$ & $x$ & $\mathrm{X}$ \\
\hline & Ranidae & Rana catesbeiana & American bullfrog & $\mathrm{X}$ & $x$ & $X$ \\
\hline \multirow[t]{16}{*}{ Squamata } & Crotaphytidae & Crotaphytus collaris & eastern collared lizard & $\mathrm{X}$ & $x$ & \\
\hline & Phrynosomatidae & Sceloporus poinsettii & crevice spiny lizard & $x$ & $x$ & \\
\hline & & Sceloporus clarkii & Clark's spiny lizard & $\mathrm{X}$ & $x$ & 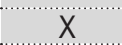 \\
\hline & & Sceloporus undulatus & eastern fence lizard & $\mathrm{X}$ & $\mathrm{X}$ & $\mathrm{X}$ \\
\hline & & Urosaurus ornatus & ornate tree lizard & $\mathrm{X}$ & $X$ & $X$ \\
\hline & & Phrynosoma hernandesi & greater short-horned lizard & $X$ & $\mathrm{X}$ & $\mathrm{X}$ \\
\hline & Teiidae & Cnemidophorus exsanguis & Chihuahuan spotted whiptail & $x$ & $x$ & $X$ \\
\hline & Anguidae & Elgaria kingii & Madrean alligator lizard & $\mathrm{X}$ & $\mathrm{X}$ & $\mathrm{X}$ \\
\hline & Colubridae & Diadophis punctatus & ring-necked snake & $\mathrm{X}$ & & \\
\hline & & Masticophis taeniatus & striped whipsnake & $\mathrm{X}$ & & $\mathrm{X}$ \\
\hline & & Salvadora grahamiae & mountain patch-nosed snake & $x$ & & $x$ \\
\hline & & Pituophis catenifer & gopher snake & $\mathrm{X}$ & & $\mathrm{X}$ \\
\hline & & Thamnophis rufipunctatus & narrow-headed gartersnake ${ }^{\mathrm{a}}$ & $\mathrm{X}$ & $\mathrm{X}$ & \\
\hline & & Thamnophis elegans & western terrestrial gartersnake & $x$ & $x$ & \\
\hline & & Thamnophis cyrtopsis & black-necked gartersnake & $\mathrm{X}$ & $\mathrm{X}$ & $X$ \\
\hline & Viperidae & Crotalus molossus & black-tailed rattlesnake & $x$ & $X$ & $\mathrm{X}$ \\
\hline
\end{tabular}

a Species have the following conservation designations: "Sensitive" species, U.S. Forest Service (Region 3) and Bureau of Land Management; "Species of concern," U.S. Fish and Wildlife Service. Arizona toad is considered "sensitive" and the narrow-headed gartersnake is considered "threatened" by the New Mexico Game and Fish Department. Data from BISON (2004). 
Appendix C. Number of observations of bird species by survey type by University of Arizona Inventory personnel, Gila Cliff Dwellings NM, 2001 and 2002. Numbers of observations are not scaled by search effort and should not be used for comparison among species or survey types. Underlined species are neotropical migrants (from Rappole 1995).

\begin{tabular}{|c|c|c|c|c|c|c|}
\hline \multirow[b]{2}{*}{ Order } & \multirow[b]{2}{*}{ Family } & \multirow[b]{2}{*}{ Scientific name } & \multirow[b]{2}{*}{ Common name } & \multicolumn{3}{|c|}{ Survey type } \\
\hline & & & & VCP & Incidental & Nocturnal \\
\hline \multirow[t]{2}{*}{ Anseriformes } & Anatidae & Anas platyrhynchos & mallard & 7 & & \\
\hline & & Mergus merganser & common merganser & 10 & 5 & \\
\hline \multirow[t]{3}{*}{ Galliformes } & Phasianidae & Meleagris gallopavo & wild turkey & 3 & 7 & \\
\hline & Odontophoridae & Callipepla gambelii & Gambel's quail & 1 & 1 & \\
\hline & & Cyrtonyx montezumae & Montezuma quail & & 5 & \\
\hline \multirow[t]{2}{*}{ Ciconiiformes } & Ardeidae & Ardea herodias & great blue heron & 7 & 14 & \\
\hline & Cathartidae & Cathartes aura & turkey vulture & 8 & 56 & \\
\hline \multirow[t]{7}{*}{ Falconiformes } & Accipitridae & Accipiter cooperii & Cooper's hawk & & 1 & \\
\hline & & Buteogallus anthracinus & common black-hawk a,b & & 3 & \\
\hline & & Buteo albonotatus & zone-tailed hawk & 1 & & \\
\hline & & Buteo jamaicensis & red-tailed hawk & 3 & 1 & \\
\hline & & Aquila chrysaetos & golden eagle & 1 & & \\
\hline & Falconidae & Falco sparverius & American kestrel & 8 & 2 & \\
\hline & & Falco peregrinus & peregrine falcon $a, b, c$ & & 2 & \\
\hline \multirow[t]{2}{*}{ Charadrifformes } & Charadriidae & Charadrius vociferus & killdeer & 1 & 3 & \\
\hline & Scolopacidae & Actitis macularia & spotted sandpiper & 1 & 2 & \\
\hline \multirow[t]{2}{*}{ Columbiformes } & Columbidae & Patagioenas fasciata & band-tailed pigeon & & 2 & \\
\hline & & Zenaida macroura & mourning dove & 58 & 12 & \\
\hline \multirow[t]{3}{*}{ Strigiformes } & Strigidae & Megascops kennicottii & western screech-owl & & & 1 \\
\hline & & Bubo virginianus & great horned owl & & 2 & 1 \\
\hline & & Glaucidium gnoma & northern pygmy-owl & 2 & & \\
\hline \multirow[t]{2}{*}{ Caprimulgiformes } & Caprimulgidae & Chordeiles minor & common nighthawk & 1 & 3 & 2 \\
\hline & & Phalaenoptilus nuttallii & common poorwill & & & 1 \\
\hline \multirow[t]{5}{*}{ Apodiformes } & Apodidae & Aeronautes saxatalis & white-throated swift & 2 & 5 & \\
\hline & Trochilidae & Archilochus alexandri & black-chinned hummingbird & 3 & 15 & \\
\hline & & Stellula calliope & calliope hummingbird & 1 & 5 & \\
\hline & & Selasphorus platycercus & broad-tailed hummingbird & 21 & 17 & \\
\hline & & Selasphorus rufus & rufous hummingbird & 3 & 38 & \\
\hline Coracilformes & Alcedinidae & Ceryle alcyon & belted kingfisher ${ }^{\mathrm{b}}$ & & 3 & \\
\hline \multirow[t]{4}{*}{ Piciformes } & Picidae & Melanerpes formicivorus & acorn woodpecker & 33 & 3 & \\
\hline & & Sphyrapicus nuchalis & red-naped sapsucker & 2 & & \\
\hline & & Picoides villosus & hairy woodpecker & 11 & 5 & \\
\hline & & Colaptes auratus & northern flicker & 46 & 3 & \\
\hline \multirow[t]{21}{*}{ Passeriformes } & Tyrannidae & Contopus sordidulus & western wood-pewee & 21 & 8 & \\
\hline & & Empidonax wrightii & gray flycatcher & 2 & & \\
\hline & & Empidonax occidentalis & cordilleran flycatcher & 18 & 3 & \\
\hline & & Sayornis nigricans & black phoebe & 7 & 8 & \\
\hline & & Sayornis saya & Say's phoebe & 2 & 5 & \\
\hline & & Myiarchus tuberculifer & dusky-capped flycatcher & 1 & & \\
\hline & & Myiarchus cinerascens & ash-throated flycatcher & 31 & 6 & \\
\hline & & Tyrannus vociferans & Cassin's kingbird & 9 & 20 & \\
\hline & Vireonidae & Vireo bellii & Bell's vireo $o^{a, b}$ & 1 & & \\
\hline & & Vireo plumbeus & plumbeous vireo & 22 & 3 & \\
\hline & & Vireo gilvus & warbling vireo & 43 & 2 & \\
\hline & Corvidae & Cyanocitta stelleri & Steller's jay & 44 & 1 & \\
\hline & & Aphelocoma californica & western scrub-jay & 31 & 7 & \\
\hline & & Gymnorhinus cyanocephalus & pinyon jay & 45 & & \\
\hline & & Corvus corax & common raven & 30 & 8 & \\
\hline & Hirundinidae & Progne subis & purple martin & 70 & 8 & \\
\hline & & Tachycineta thalassina & violet-green swallow & 166 & 62 & \\
\hline & & Stelgidopteryx serripennis & northern rough-winged swallow & 2 & 7 & \\
\hline & & Petrochelidon pyrrhonota & cliff swallow & 4 & 62 & \\
\hline & & Hirundo rustica & barn swallow & 1 & & \\
\hline & Paridae & Poecile gambeli & mountain chickadee & 5 & & \\
\hline
\end{tabular}




\begin{tabular}{|c|c|c|c|c|c|c|}
\hline \multirow[b]{2}{*}{ Order } & \multirow[b]{2}{*}{ Family } & \multirow[b]{2}{*}{ Scientific name } & \multirow[b]{2}{*}{ Common name } & \multicolumn{3}{|c|}{ Survey type } \\
\hline & & & & VCP & Incidental & Nocturnal \\
\hline \multirow[t]{53}{*}{ Passeriformes } & Paridae & Baeolophus wollweberi & bridled titmouse & 8 & 4 & \\
\hline & & Baeolphus ridgwayi & juniper titmouse & & 3 & \\
\hline & Aegithalidae & Psaltriparus minimus & bushtit & 55 & 27 & \\
\hline & Sittidae & Sitta carolinensis & white-breasted nuthatch & 12 & 4 & \\
\hline & & Sitta pygmaea & pygmy nuthatch & 14 & & \\
\hline & Troglodytidae & Salpinctes obsoletus & rock wren & 3 & 2 & \\
\hline & & Catherpes mexicanus & canyon wren & 29 & 8 & \\
\hline & & Thryomanes bewickii & Bewick's wren & 7 & 1 & \\
\hline & & Troglodytes aedon & house wren & 80 & 4 & \\
\hline & Sylviidae & Polioptila caerulea & blue-gray gnatcatcher & 8 & 3 & \\
\hline & Turdidae & Sialia mexicana & western bluebird & 2 & 11 & \\
\hline & & Myadestes townsendi & Townsend's solitaire & 1 & & \\
\hline & & Catharus guttatus & hermit thrush & & 1 & \\
\hline & & Turdus migratorius & American robin & 98 & 13 & \\
\hline & Mimidae & Dumetella carolinensis & gray catbird $^{\mathrm{b}}$ & 1 & & \\
\hline & & Mimus polyglottos & northern mockingbird & 1 & 2 & \\
\hline & & Toxostoma curvirostre & curve-billed thrasher & 1 & & \\
\hline & Peucedramidae & Peucedramus taeniatus & olive warbler & 1 & & \\
\hline & Parulidae & Vermivora celata & orange-crowned warbler & & 2 & \\
\hline & & Vermivora virginiae & Virginia's warbler & 38 & & \\
\hline & & Dendroica petechia & yellow warbler & 7 & 21 & \\
\hline & & Dendroica coronata & yellow-rumped warbler & 3 & 1 & \\
\hline & & Dendroica nigrescens & black-throated gray warbler & 8 & 7 & \\
\hline & & Dendroica townsendi & Townsend's warbler & 2 & & \\
\hline & & Dendroica graciae & Grace's warbler & 2 & 1 & \\
\hline & & Oporornis tolmiei & Macgillivray's warbler & 4 & 2 & \\
\hline & & Geothlypis trichas & common yellowthroat & 1 & 2 & \\
\hline & & Wilsonia pusilla & Wilson's warbler & 8 & 3 & \\
\hline & & Cardellina rubrifrons & red-faced warbler & 11 & & \\
\hline & & Myioborus pictus & painted redstart & 43 & 4 & \\
\hline & & Icteria virens & yellow-breasted chat & 43 & 6 & \\
\hline & Thraupidae & Piranga flava & hepatic tanager & 22 & 8 & \\
\hline & & Piranga ludoviciana & western tanager & 50 & 4 & \\
\hline & Emberizidae & Pipilo chlorurus & green-tailed towhee & 5 & 2 & \\
\hline & & Pipilo maculatus & spotted towhee & 127 & 17 & \\
\hline & & Pipilo fuscus & canyon towhee & 12 & 12 & \\
\hline & & Spizella passerina & chipping sparrow & 4 & 4 & \\
\hline & & Spizella breweri & Brewer's sparrow & & 1 & \\
\hline & & Chondestes grammacus & lark sparrow & 3 & 24 & \\
\hline & & Melospiza lincolnii & Lincoln's sparrow & 2 & 3 & \\
\hline & & Zonotrichia leucophrys & white-crowned sparrow & 2 & 2 & \\
\hline & & Junco hyemalis & dark-eyed junco & 12 & & \\
\hline & Cardinalidae & Pheucticus melanocephalus & black-headed grosbeak & 70 & 4 & \\
\hline & & Passerina caerulea & blue grosbeak & 20 & 13 & \\
\hline & & Passerina amoena & lazuli bunting & & 8 & \\
\hline & & Passerina cyanea & indigo bunting & & 2 & \\
\hline & Icteridae & $\frac{\text { Xanthocephalus }}{\text { xanthocephalus }}$ & yellow-headed blackbird & & 1 & \\
\hline & & Euphagus cyanocephalus & Brewer's blackbird & 12 & 1 & \\
\hline & & Molothrus ater & brown-headed cowbird & 20 & 5 & \\
\hline & & Icterus bullockii & Bullock's oriole & 4 & 8 & \\
\hline & Fringillidae & Carpodacus mexicanus & house finch & 2 & 19 & \\
\hline & & Loxia curvirostra & red crossbill & 1 & & \\
\hline & & Carduelis psaltria & lesser goldfinch & 18 & 26 & \\
\hline Number of spec & & & & 91 & 84 & 4 \\
\hline
\end{tabular}

a "Threatened"; New Mexico Game and Fish Department (BISON 2004).

b "Sensitive"; U.S. Forest Service (BISON 2004).

c "Species of Concern"; U.S. Fish and Wildlife Service (BISON 2004). 
Appendix D. Number of observations of mammal species by survey type by University of Arizona Inventory personnel, Gila Cliff Dwellings NM, 2001 and 2002. Underlined species indicate that we obtained voucher specimen(s) and/or photograph(s) a .

\begin{tabular}{|c|c|c|c|c|c|c|c|}
\hline \multirow[b]{2}{*}{ Order } & \multirow[b]{2}{*}{ Family } & \multirow[b]{2}{*}{ Scientific name } & \multirow[b]{2}{*}{ Common name } & \multicolumn{4}{|c|}{ Survey type } \\
\hline & & & & $\begin{array}{c}\text { Bat } \\
\text { netting }\end{array}$ & $\begin{array}{c}\text { Small } \\
\text { mammal } \\
\text { trapping }\end{array}$ & $\begin{array}{l}\text { Trail- } \\
\text { master I }\end{array}$ & Incidental \\
\hline Insectivora & Soricidae & Notiosorex crawfordi & desert shrew & & & & 1 \\
\hline \multirow{8}{*}{ Chiroptera } & Vespertilionidae & Myotis occultus & Arizona myotis & 10 & & & \\
\hline & & Myotis auriculus & southwestern myotis & 2 & & & \\
\hline & & Myotis californicus & California myotis & 1 & & & \\
\hline & & Lasionycteris noctivagans & silver-haired bat & 16 & & & \\
\hline & & Eptesicus fuscus & big brown bat & 6 & & & \\
\hline & & Lasiurus cinereus & hoary bat & 8 & & & \\
\hline & Molossidae & Tadarida brasiliensis & Mexican freetail bat & 21 & & & \\
\hline & & Nyctinomops macrotis & big freetail bat & 1 & & & \\
\hline \multirow[t]{8}{*}{ Carnivora } & Ursidae & Ursus americanus & American black bear & & & 2 & 3 \\
\hline & Procyonidae & Procyon lotor & northern raccoon & & & & 1 \\
\hline & Mephitidae & Mephitis mephitis & striped skunk & & & 10 & \\
\hline & & Mephitis macroura & hooded skunk & & & & \\
\hline & & Conepatus mesoleucus & white-backed hog-nosed skunk & & & 9 & \\
\hline & Canidae & Canis latrans & coyote & & & & 1 \\
\hline & & Urocyon cinereoargenteus & common gray fox & & & 12 & \\
\hline & Felidae & Puma concolor & mountain lion & & & 2 & 8 \\
\hline \multirow[t]{13}{*}{ Rodentia } & Sciuridae & Spermophilus variegatus & rock squirrel & & & 1 & 4 \\
\hline & & Neotamias dorsalis & cliff chipmunk & & 3 & & 3 \\
\hline & & Sciurus aberti & Abert's squirrel & & & 1 & 1 \\
\hline & Geomyidae & Thomomys bottae & Botta's pocket gopher & & 1 & & \\
\hline & Castoridae & Castor canadensis & American beaver ${ }^{b}$ & & & & 5 \\
\hline & Muridae & Reithrodontomys megalotis & western harvest mouse & & 54 & & \\
\hline & & Peromyscus maniculatus & deer mouse & & 6 & & \\
\hline & & Peromyscus boylii & brush mouse & & 160 & & \\
\hline & & Peromyscus truei & piñon mouse & & 4 & & \\
\hline & & Neotoma albigula & western white-throated woodrat & & 47 & & \\
\hline & & Neotoma mexicana & Mexican woodrat & & 5 & & \\
\hline & & Microtus mexicanus & Mexican vole & & 3 & & \\
\hline & & Ondatra zibethicus & common muskrat ${ }^{b}$ & & & & 1 \\
\hline \multirow[t]{2}{*}{ Lagomorpha } & Leporidae & Lepus californicus & black-tailed jackrabbit ${ }^{6}$ & & & & 4 \\
\hline & & Sylvilagus audubonii & desert cottontail & & & & \\
\hline \multirow[t]{4}{*}{ Artiodactyla } & Tayassuidae & Pecari tajacu & collared peccary & & & 3 & \\
\hline & Cervidae & Cervus canadensis & elk & & & 2 & 4 \\
\hline & & Odocoileus hemionus & mule deer & & & & 7 \\
\hline & & Odocoileus virginianus & white-tailed deer ${ }^{b}$ & & & & 1 \\
\hline \multicolumn{4}{|c|}{ Number of species } & 8 & 9 & 9 & 14 \\
\hline
\end{tabular}

a See Appendix $\mathrm{H}$ for additional information.

${ }^{\mathrm{b}}$ Observed only outside of monument boundary but within $500 \mathrm{~m}$ of the TJ Ruins site near the Middle Fork of the Gila River. 
Appendix E. Amphibian and reptile species that were not recorded by University of Arizona Inventory personnel but that may occur at Gila Cliff Dwellings NM. Species may occur based on documentation in the area outside of the monument by UA personnel, specimen collected in or near the monument and reported in Degenhardt et al. (1996), or by other sources.

\begin{tabular}{|c|c|c|c|c|c|c|}
\hline \multirow[b]{2}{*}{ Order } & \multirow[b]{2}{*}{ Family } & \multirow[b]{2}{*}{ Scientific name } & \multirow[b]{2}{*}{ Common name } & \multicolumn{3}{|c|}{ Found by UA } \\
\hline & & & & $\begin{array}{l}\text { Degenhardt } \\
\text { et al. (1996) }\end{array}$ & $\begin{array}{l}\text { outside of } \\
\text { boundary }\end{array}$ & $\begin{array}{l}\text { Specimen } \\
\text { at MSB }\end{array}$ \\
\hline Caudata & Ambystomatidae & Ambystoma tigrinum & tiger salamander & $x$ & & $X$ \\
\hline \multirow[t]{5}{*}{ Anura } & Pelobatidae & Spea multiplicata & Mexican spadefoot & $\mathrm{X}$ & & \\
\hline & Bufonidae & Bufo woodhousii & Woodhouse's toad & X & & X \\
\hline & & Bufo punctatus & red-spotted toad & $\mathrm{X}$ & & \\
\hline & Hylidae & Hyla eximia & mountain treefrog & $\mathrm{X}$ & & \\
\hline & Ranidae & Rana chiricahuensis & Chiricahua leopard frog & $\mathrm{X}$ & & $\mathrm{X}$ \\
\hline \multirow[t]{3}{*}{ Testudines } & Kinosternidae & Kinosternon sonoriense & Sonoran mud turtle & $\mathrm{X}$ & & \\
\hline & Emydidae & Terrapene ornata & western box turtle & & X & \\
\hline & Trionychidae & Trionyx spiniferus & spiny softshell turtle & & & \\
\hline \multirow[t]{9}{*}{ Squamata } & Phrynosomatidae & Sceloporus magister & desert spiny lizard & $X$ & & \\
\hline & Scincidae & Eumeces multivirgatus & many-lined skink & $\mathrm{X}$ & & \\
\hline & & Eumeces obsoletus & Great Plains skink & $\mathrm{X}$ & & \\
\hline & Teiidae & Cnemidophorus uniparens & desert grassland whiptail & $\mathrm{X}$ & & \\
\hline & & Lampropeltis pyromelana & Sonoran mountain kingsnake & $X$ & $X$ & \\
\hline & Colubridae & Hypsiglena torquata & night snake & $\mathrm{X}$ & & \\
\hline & & Thamnophis marcianus & checkered gartersnake & $X$ & & \\
\hline & Viperidae & Crotalus lepidus & rock rattlesnake & $\mathrm{X}$ & & \\
\hline & & Crotalus viridis & western rattlesnake & $X$ & & \\
\hline
\end{tabular}

${ }^{a}$ Museum of Southwestern Biology, University of New Mexico. See Appendix I for additional information. 
Appendix F. Bird species that were not observed by University of Arizona Inventory personnel but that may occur at Gila Cliff Dwellings NM. List taken from Zimmerman (1995) and includes all species in each residence status except those listed as "rare." List only includes those species that Zimmerman listed as being present in the oak-juniper, pinyon-juniper, ponderosa pine, and deciduous riparian vegetation types.

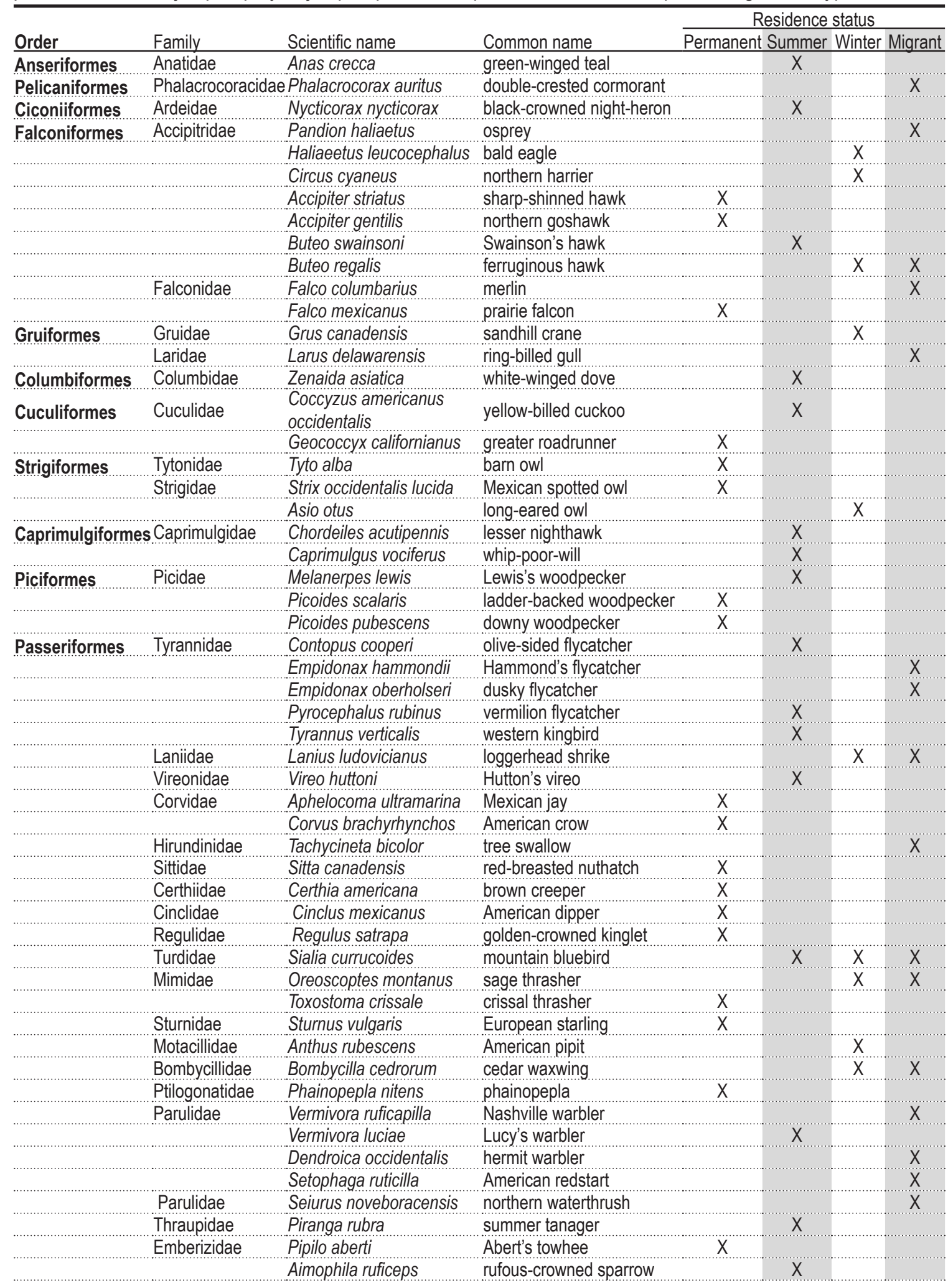




\begin{tabular}{|c|c|c|c|c|c|c|c|}
\hline \multirow[b]{2}{*}{ Order } & \multirow[b]{2}{*}{ Family } & \multirow[b]{2}{*}{ Scientific name } & \multirow[b]{2}{*}{ Common name } & \multicolumn{4}{|c|}{ Residence status } \\
\hline & & & & Permane & Summer & Winter & Migrant \\
\hline \multirow{11}{*}{ Passeriformes } & Emberizidae & Spizella atrogularis & black-chinned sparrow & & $x$ & & \\
\hline & & Melospiza melodia & song sparrow & & & $x$ & \\
\hline & Cardinalidae & Cardinalis cardinalis & northern cardinal & $x$ & & & \\
\hline & & Cardinalis sinuatus & pyrrhuloxia & & & $x$ & \\
\hline & Icteridae & Agelaius phoeniceus & red-winged blackbird & & $\mathrm{X}$ & $\mathrm{X}$ & $X$ \\
\hline & & Quiscalus mexicanus & great-tailed grackle & X & & & \\
\hline & & Icterus parisorum & Scott's oriole & & 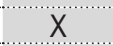 & & \\
\hline & Fringillidae & Carpodacus cassinii & Cassin's finch & & & $\mathrm{X}$ & $X$ \\
\hline & & Carduelis pinus & pine siskin & & $x$ & $x$ & $\mathrm{X}$ \\
\hline & & Carduelis tristis & American goldfinch & & & $x$ & \\
\hline & Passeridae & Passer domesticus & house sparrow & X & & & \\
\hline \multicolumn{3}{|c|}{ Number of species } & & 21 & 20 & 16 & 10 \\
\hline
\end{tabular}


Appendix G. Mammal species that were not recorded by University of Arizona Inventory personnel but that are known to or may occur at Gila Cliff Dwellings NM. List based on range maps by Findley et al. (1975) and trapping or observations at or near the monument by Hayward and Hunt (1972).

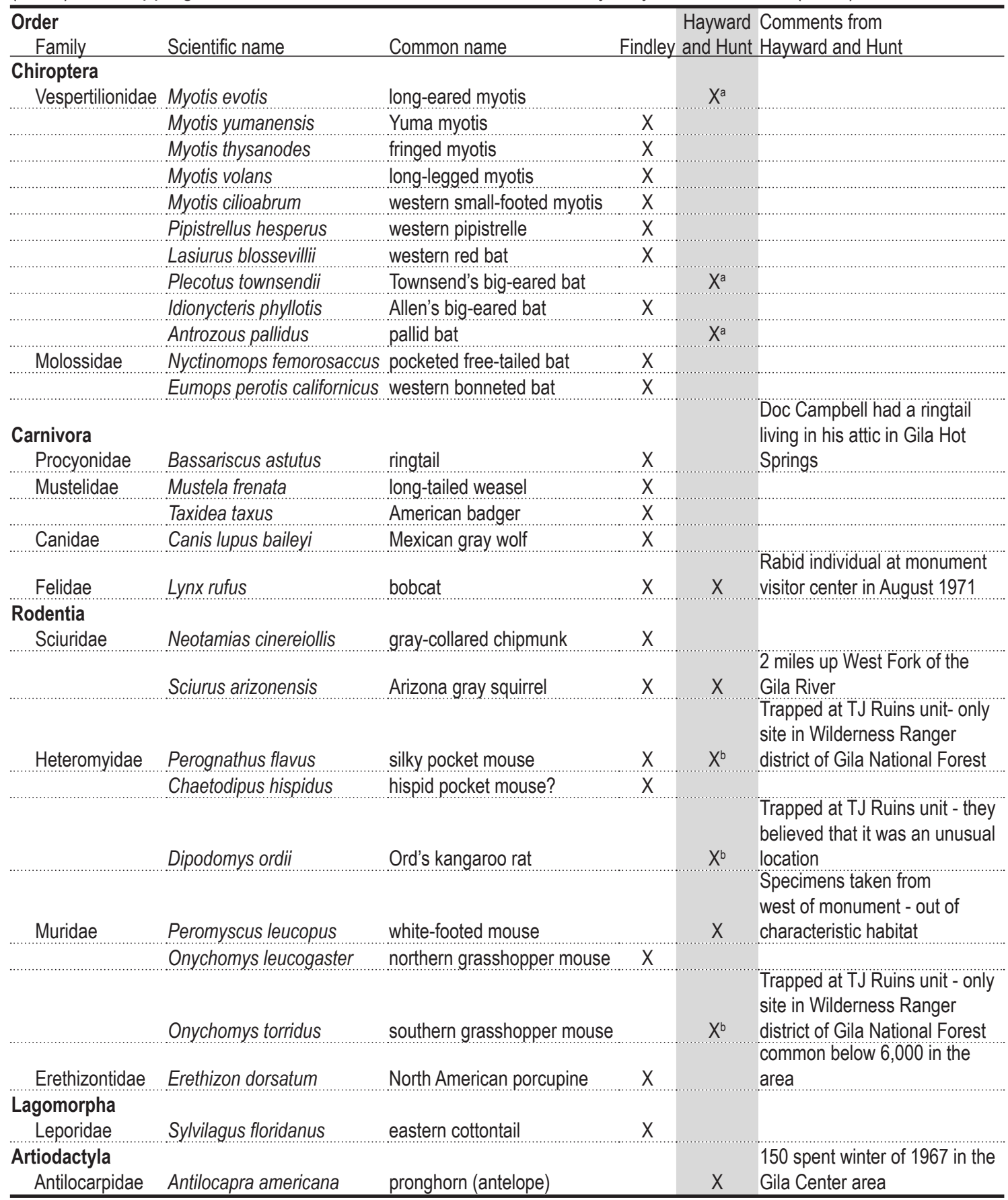

${ }^{a}$ B. J. Hayward in personal communication to Ronnie Sidner (2001); bats were caught at the monument in 1965.

${ }^{\mathrm{b}}$ To our knowledge, no specimens are known to have been accessioned from these collections. 
Appendix H. Vertebrate specimen and photograph vouchers collected by University of Arizona Inventory personnel, Gila Cliff Dwellings NM, 2001 and 2002. All specimen vouchers are located in University of Arizona (AZ) collections.

\begin{tabular}{|c|c|c|c|c|c|}
\hline $\begin{array}{l}\text { Voucher type } \\
\text { Taxon }\end{array}$ & Species & Collector(s) & $\begin{array}{l}\text { Date of } \\
\text { collection }\end{array}$ & $\begin{array}{l}\text { AZ } \\
\text { collection \# }\end{array}$ & $\begin{array}{l}\text { Specimen } \\
\text { type }\end{array}$ \\
\hline \multicolumn{6}{|c|}{ Specimen } \\
\hline \multirow[t]{3}{*}{ Amphibian } & Arizona toad & Emily Bennett & $7 / 6 / 2001$ & 53627 & whole \\
\hline & canyon treefrog & Michael Wall & $5 / 27 / 2001$ & 53398 & whole \\
\hline & American bullfrog & James Borgmeyer & $5 / 26 / 2001$ & 53397 & whole \\
\hline \multirow[t]{20}{*}{ Reptile } & Clark's spiny lizard & Emily Bennett & $6 / 3 / 2002$ & & whole \\
\hline & eastern fence lizard & Kevin Bonine and Dan Bell & $8 / 6 / 2002$ & & whole \\
\hline & ornate tree lizard & Trish London & $5 / 27 / 2002$ & & whole \\
\hline & greater short-horned lizard & Michael Wall & $5 / 27 / 2001$ & 53396 & whole \\
\hline & Chihuahuan spotted whiptail & James Borgmeyer & $5 / 29 / 2001$ & 53394 & whole \\
\hline & Chihuahuan spotted whiptail & Emily Bennett & $7 / 16 / 2001$ & 53628 & whole \\
\hline & Chihuahuan spotted whiptail & Emily Bennett & $8 / 5 / 2002$ & & whole \\
\hline & Madrean alligator lizard & James Borgmeyer & $5 / 25 / 2001$ & 53395 & whole \\
\hline & Madrean alligator lizard & Anita Deming & $7 / 26 / 2002$ & & whole \\
\hline & striped whipsnake & Trishia London & $7 / 4 / 2001$ & 53635 & whole \\
\hline & mountain patch-nosed snake & Jimmy Wethington & $7 / 28 / 2001$ & 53632 & whole \\
\hline & mountain patch-nosed snake & Laura Zuiler & $9 / 3 / 2001$ & 53683 & whole \\
\hline & gopher snake & Monument staff & $5 / 11 / 2001$ & 53392 & whole \\
\hline & gopher snake & Michael Wall & $5 / 27 / 2001$ & 53393 & whole \\
\hline & gopher snake & Emily Bennett & $7 / 21 / 2001$ & 53633 & whole \\
\hline & gopher snake & Trishia London & $7 / 8 / 2001$ & 53634 & whole \\
\hline & black-necked gartersnake & Emily Bennett & $7 / 10 / 2001$ & 53629 & whole \\
\hline & black-necked gartersnake & Trishia London & $8 / 5 / 2001$ & 53630 & whole \\
\hline & black-necked gartersnake & Jimmy Wethington & $8 / 10 / 2001$ & 53682 & whole \\
\hline & black-tailed rattlesnake & Trishia London & $8 / 3 / 2001$ & 53675 & whole \\
\hline \multirow[t]{32}{*}{ Mammal } & desert shrew & Neil Perry & $9 / 3 / 2001$ & 26829 & Skin and skull \\
\hline & Arizona myotis & Ronnie Sidner & $6 / 22 / 2002$ & 26935 & Skull \\
\hline & Arizona myotis & Ronnie Sidner & $6 / 21 / 2002$ & 26842 & Skin and skull \\
\hline & Arizona myotis & Ronnie Sidner & $6 / 22 / 2002$ & 26936 & Skull \\
\hline & southwestern myotis & Ronnie Sidner & $9 / 4 / 2002$ & & Skin and skull \\
\hline & silver-haired bat & Ronnie Sidner & $5 / 27 / 2001$ & 26896 & Skin and skull \\
\hline & big brown bat & Ronnie Sidner & $5 / 29 / 2001$ & 26840 & Skin and skull \\
\hline & northern raccoon & Jason Schmidt & $5 / 16 / 2001$ & & Maxilla \\
\hline & northern raccoon & Dale Turner & $5 / 15 / 2001$ & 26773 & Skull \\
\hline & hooded skunk & Neil Perry & $8 / 28 / 2002$ & 26765 & Skull \\
\hline & white-backed hog-nosed skunk & Neil Perry & $5 / 5 / 2001$ & 26778 & Skull \\
\hline & coyote & Neil Perry & $9 / 10 / 2001$ & 26770 & Skull \\
\hline & common gray fox & Jason Schmidt & $9 / 2 / 2001$ & Submitted Fall 2001 & Skull \\
\hline & cliff chipmunk & Neil Perry & $8 / 18 / 2001$ & 26749 & Skin \\
\hline & Botta's pocket gopher & Emily Bennett & $9 / 15 / 2002$ & 26883 & Skin and skull \\
\hline & Botta's pocket gopher & Neil Perry & $5 / 5 / 2002$ & 26927 & Skull \\
\hline & American beaver & Neil Perry & $8 / 22 / 2001$ & 26777 & Skull \\
\hline & western harvest mouse & Neil Perry & $5 / 26 / 2001$ & 26825 & Skin and skull \\
\hline & western harvest mouse & Emily Bennett & $4 / 22 / 2002$ & 26869 & Skin and skull \\
\hline & deer mouse & Emily Bennett & $4 / 20 / 2002$ & 26881 & Skin and skull \\
\hline & brush mouse & Emily Bennett & $4 / 21 / 2002$ & 26919 & Skull \\
\hline & piñon mouse & Neil Perry & $9 / 4 / 2001$ & 26828 & Skin and skull \\
\hline & piñon mouse & Emily Bennett & $9 / 10 / 2002$ & 26872 & Skin and skull \\
\hline & piñon mouse & Emily Bennett & 9/6/2002 & 26882 & Skin and skull \\
\hline & piñon mouse & Neil Perry & $5 / 26 / 2001$ & 26831 & Skin and skull \\
\hline & western white-throated woodrat & Emily Bennett & $8 / 11 / 2002$ & 26847 & Skin and skull \\
\hline & Mexican woodrat & Emily Bennett & $9 / 8 / 2002$ & 26926 & Skull \\
\hline & Mexican woodrat & Neil Perry & $5 / 26 / 2001$ & 26750 & Skin \\
\hline & Mexican vole & Emily Bennett & $7 / 16 / 2002$ & 26871 & Skin and skull \\
\hline & desert cottontail & Neil Perry & $10 / 9 / 2001$ & 26781 & Skull and mandible \\
\hline & elk & Jason Schmidt & $5 / 30 / 2001$ & 26764 & Skull no antlers \\
\hline & mule deer & Neil Perry & $5 / 26 / 2001$ & 26776 & Skull \\
\hline
\end{tabular}




\begin{tabular}{|c|c|c|c|c|}
\hline $\begin{array}{l}\text { Voucher type } \\
\text { Taxon }\end{array}$ & Species & Collector(s) & $\begin{array}{ll}\text { Date of } & A Z \\
\text { collection } & \text { collection \# }\end{array}$ & $\begin{array}{l}\text { Specimen } \\
\text { type }\end{array}$ \\
\hline \multicolumn{5}{|l|}{ Photograph } \\
\hline \multirow[t]{4}{*}{ Amphibian } & canyon treefrog & Dave Prival & $5 / 27 / 2001$ & \\
\hline & American bullfrog & Dave Prival & $5 / 26 / 2001$ & \\
\hline & American bullfrog & Dave Prival & $5 / 26 / 2001$ & \\
\hline & Arizona toad & Kevin Bonine & $6 / 27 / 2002$ & \\
\hline \multirow[t]{24}{*}{ Reptile } & Chihuahuan spotted whiptail & Dave Prival & $5 / 26 / 2001$ & \\
\hline & Chihuahuan spotted whiptail & Dave Prival & $5 / 26 / 2001$ & \\
\hline & Madrean alligator lizard & Dave Prival & $5 / 25 / 2001$ & \\
\hline & greater short-horned lizard & Dave Prival & $5 / 29 / 2001$ & \\
\hline & greater short-horned lizard & Dave Prival & $5 / 29 / 2001$ & \\
\hline & crevice spiny lizard & Dave Prival & $5 / 27 / 2001$ & \\
\hline & crevice spiny lizard & Dave Prival & $5 / 27 / 2001$ & \\
\hline & eastern fence lizard & Dave Prival & $5 / 26 / 2001$ & \\
\hline & eastern fence lizard & Dave Prival & $5 / 26 / 2001$ & \\
\hline & ornate tree lizard & Dave Prival & $5 / 26 / 2001$ & \\
\hline & black-tailed rattlesnake & Dave Prival & $5 / 30 / 2001$ & \\
\hline & black-tailed rattlesnake & Dave Prival & $5 / 30 / 2001$ & \\
\hline & black-necked gartersnake & Dave Prival & $5 / 29 / 2001$ & \\
\hline & black-necked gartersnake & Dave Prival & $5 / 29 / 2001$ & \\
\hline & gopher snake & Dave Prival & $8 / 20 / 2001$ & \\
\hline & western terrestrial gartersnake & Dave Prival & $5 / 26 / 2001$ & \\
\hline & western terrestrial gartersnake & Dave Prival & $5 / 26 / 2001$ & \\
\hline & eastern collared lizard & Dave Prival & $8 / 21 / 2001$ & \\
\hline & eastern collared lizard & Dave Prival & $8 / 21 / 2001$ & \\
\hline & narrow-headed gartersnake & Dan Bell & $8 / 7 / 2002$ & \\
\hline & narrow-headed gartersnake & Dan Bell & $8 / 7 / 2002$ & \\
\hline & gopher snake & Emily Bennett & $6 / 13 / 2001$ & \\
\hline & western box turtle & Emily Bennett & $7 / 24 / 2001$ & \\
\hline & Clark's spiny lizard & Emily Bennett & $6 / 3 / 2002$ & \\
\hline \multirow[t]{2}{*}{ Bird } & wild turkey & Emily Bennett/Neil Perry & $10 / 15 / 2001$ & \\
\hline & great blue heron & Ronnie Sidner & $6 / 21 / 2002$ & \\
\hline \multirow[t]{17}{*}{ Mammal } & mountain lion & Emily Bennett/Neil Perry & $8 / 26 / 2002$ & \\
\hline & Abert's squirrel & Emily Bennett/Neil Perry & $6 / 23 / 2002$ & \\
\hline & collared peccary & Emily Bennett/Neil Perry & $10 / 15 / 2001$ & \\
\hline & American black bear & Emily Bennett/Neil Perry & $10 / 15 / 2001$ & \\
\hline & American black bear & Emily Bennett/Neil Perry & $10 / 15 / 2001$ & \\
\hline & white-backed hog-nosed skunk & Emily Bennett/Neil Perry & $12 / 11 / 2001$ & \\
\hline & white-backed hog-nosed skunk & Emily Bennett/Neil Perry & $12 / 11 / 2001$ & \\
\hline & wapiti & Emily Bennett/Neil Perry & $6 / 17 / 2002$ & \\
\hline & striped skunk & Emily Bennett/Neil Perry & $6 / 17 / 2002$ & \\
\hline & striped skunk & Emily Bennett/Neil Perry & $6 / 17 / 2002$ & \\
\hline & common gray fox & Emily Bennett/Neil Perry & $6 / 17 / 2002$ & \\
\hline & common gray fox & Emily Bennett/Neil Perry & $6 / 17 / 2002$ & \\
\hline & black-tailed jackrabbit & Emily Bennett & $7 / 7 / 2002$ & \\
\hline & big brown bat & Ronnie Sidner & $5 / 26 / 2001$ & \\
\hline & Brazilian free-tailed bat & Ronnie Sidner & $5 / 26 / 2001$ & \\
\hline & silver-haired bat & Ronnie Sidner & $5 / 26 / 2001$ & \\
\hline & northern raccoon & Emily Bennett & $5 / 28 / 2001$ & \\
\hline \multirow[t]{2}{*}{ Mammal } & cliff chipmunk & Neil Perry & $5 / 28 / 2001$ & \\
\hline & rock squirrel & Emily Bennett & $6 / 30 / 2001$ & \\
\hline
\end{tabular}


Appendix I. Number of amphibian and reptile specimen vouchers located at the Museum of Southwestern Biology, University of New Mexico. Location information indicates that specimens were collected either from inside or outside (but within $30 \mathrm{~km}$ ) of Gila Cliff Dwellings NM.

\begin{tabular}{|c|c|c|}
\hline Species & $\begin{array}{l}\text { Found in } \\
\text { monument }\end{array}$ & $\begin{array}{l}\text { Found outside } \\
\text { of monument }\end{array}$ \\
\hline tiger salamander & & 1 \\
\hline Woodhouse's toad & 1 & \\
\hline Arizona toad & 1 & 12 \\
\hline canyon treefrog & & 1 \\
\hline Chiricahua leopard frog & 1 & 1 \\
\hline American bullfrog & 6 & 10 \\
\hline crevice spiny lizard & & 2 \\
\hline Clark's spiny lizard & & 1 \\
\hline eastern fence lizard & & 2 \\
\hline ornate tree lizard & & 5 \\
\hline Chihuahuan spotted whiptail & & 2 \\
\hline Madrean alligator lizard & & 1 \\
\hline narrow-headed gartersnake & 1 & 3 \\
\hline western terrestrial gartersnake & 1 & 7 \\
\hline black-necked gartersnake & & 3 \\
\hline
\end{tabular}


Appendix J. Report by Philip C. Rosen on the expected amphibians and reptiles of Gila Cliff Dwellings NM.

Gila Cliff Dwellings is a small-acreage National Monument surrounded by the Gila Wilderness, in a region at moderately high elevations of about $5600-6700 \mathrm{ft}$. While ponderosa pine is the most prominent plant species, the vegetation is mixed, and habitat conditions for herpetofauna are more varied than those presented by the core of the ponderosa forest at higher elevations.

Based on the vegetation components, the site has a diverse flora with strong elements of the mid-elevation pinyon-juniper assemblage within a matrix dominated moderately by ponderosa pine and Gambel oak - the classic Transition Life Zone dominants seen widely in Arizona. The vegetation had about 91 Transition Zone (i.e., Ponderosa, or Petran Montane Woodland-related) trees in the tree overstory and understory, versus about 81 Upper Sonoran (i.e., Pinyon-Juniper, or Great Basin Woodland-related) trees. The area was mapped as Great Basin Conifer Woodland, but corresponds to a mix with a moderate dominance of Lower Montane Coniferous Forest (Ponderosa PinePinyon Pine-Gray Oak series of Dick-Peddie 1993) over Pinyon-Juniper Woodland.

The riparian and stream environments have a middle elevation character, as indicated by species lists and the overall aspect, which is rich in marshland plants and reflects a mixture of slow and swiftly flowing waters. In the absence of introduced species, this should be an excellent aquatic system for native herpetofauna.

Overall, therefore, I expect a fairly high diversity of amphibians and reptiles, with a core of species composed of higher elevation taxa in the woodland-forest group, without the depauperate character found at higher elevations in the Transition Zone, and with some representation of lower elevation woodland taxa. In addition, there should be a strongly developed complement of aquatic species, such as gartersnakes, the Sonoran mud turtle, and aquatic anurans such as Woodhouse toad, Arizona toad, and the Chiricahua leopard frog, as well as some members of the family Hylidae.

\section{Potential and Known Herpetofauna}

Based on geographic proximity, elevational range, and habitat, a total of 49 amphibians and reptiles might potentially be found at Gila Cliff Dwellings NM (Appendices B, E). Of these, 21 are confirmed to be present, of which 20 were recorded by the NPS I\&M survey team. One species, the Chiricahua leopard frog was present historically but is presumed extirpated. An additional 5 species can be expected to occur, but may be rare and difficult to find, and 6 more are possible (including the box turtle - see below), for a total of 30 to 34 species expected in the herpetofauna.

A western box turtle was found by the I\&M survey team within about three miles from the monument, a species that would not be expected based on the criteria I used. The individual could have been translocated as a captive. However, despite a 50+ km gap between this record along the Gila River and the nearest record to the south, Degenhardt et al. (1996) reports occasional records to above $2100 \mathrm{~m}$ and discusses a possibly valid record in PinyonJuniper-Ponderosa habitat near Albuquerque. Thus, while I consider the box turtle record questionable or peripheral, needing confirmation both on-site, as a population, and with evidence of recruitment (at least with a variety of ages, but especially with young ones less than 10 or 12 years old), the observation should alert the NPS to the possibility of an unusual, higher elevation population of box turtles at or near the monument.

A similar situation may exist for the checkered gartersnake and desert spiny lizard, but at the least photo vouchers will be needed to verify their occurrence. Both are examples of typically lower elevation species occurring in higher life zones in the Gila Wilderness than elsewhere in their range (see Degenhardt et al. 1996), and both could occur at the monument and be rare, secretive, and hard to document. 
However, some of the species judged to possibly occur at the monument, may occur only at higher elevations, such as the mountain treefrog, or in special breeding environments, such as the western chorus frog.

Overall, it appears that local and regional herpetofaunal diversity is quite high on an elevation-specific basis, and the herpetofauna appears to be intact (except for some, possibly several, aquatic species) and adequately sampled overall by the University of Arizona I\&M team. The diversity corresponds to the substantial habitat diversity, whereas the threats to the aquatic species are driven first and foremost by harmful non-native species such as the American bullfrog, crayfish, and various predatory fishes.

\section{Key Features of the Herpetofauna}

The most notable part of the monument's herpetofauna appears to be the aquatic element, for which the gartersnake species list appears good both historically and currently. However, abundance declines could be ongoing in the narrow-headed gartersnake, as is being found in other areas; further, the absence of Sonoran mud turtle records and Chiricahua leopard frog records may be cause for concern. The presence of a warm spring may be significant for potential recovery of the Chiricahua leopard frog onsite, as warm- and hot-springs appear to allow the frogs to clear or avoid the emergent disease chytridiomycosis.

Secondly, the riparian component, which is not as well documented, should be strong at the monument. The nature of this herpetofaunal element at the site remains to be described. Species such as the many-lined skink, western chorus frog, and checkered gartersnake might be expected to be included, but have yet to be documented.

In the longer term, peripheral species such as the desert spiny lizard, mountain treefrog, and night snake may be added to the known herpetofauna of the monument, reflecting its transitional position on a habitat gradient that corresponds to its position on the gradient between Transition and Upper Sonoran Life Zones. 
Appendix K. Number of birds observed during VCP and incidental surveys, Gila Cliff Dwellings NM, April-July 2001 and 2002. Numbers should not used as a measure of relative abundance because there was not consistent sampling effort across time or between survey types. See Tables 5.2 and 5.3 for relative abundance of the most common species.

\begin{tabular}{|c|c|c|c|c|c|c|c|}
\hline \multirow[b]{2}{*}{ Species } & \multirow{2}{*}{$\frac{\text { April }}{15-30}$} & \multicolumn{2}{|c|}{ May } & \multicolumn{2}{|c|}{ June } & \multicolumn{2}{|c|}{ July } \\
\hline & & $1-15$ & $16-31$ & $1-15$ & $16-30$ & $1-15$ & $15-31$ \\
\hline mallard & & 5 & 2 & & & & \\
\hline common merganser & & 5 & 6 & & 1 & & 3 \\
\hline wild turkey & 1 & 1 & 1 & & & 5 & 2 \\
\hline Gambel's quail & & & & & 2 & & \\
\hline Montezuma quail & & & & & 2 & & 3 \\
\hline great blue heron & & 1 & 1 & & 13 & & 5 \\
\hline turkey vulture & 1 & 1 & 6 & & 22 & & 33 \\
\hline common black-hawk & & & & 1 & 2 & & \\
\hline zone-tailed hawk & & 1 & & & & & \\
\hline red-tailed hawk & & & 1 & & 1 & 1 & 1 \\
\hline golden eagle & & 1 & & & & & \\
\hline American kestrel & & & & 2 & 2 & 1 & 5 \\
\hline peregrine falcon & 2 & & & & & & \\
\hline killdeer & & & & 1 & 2 & & 1 \\
\hline spotted sandpiper & & & 1 & & & & 2 \\
\hline mourning dove & 1 & 18 & 12 & 11 & 17 & 2 & 9 \\
\hline great horned owl & & 1 & & & & & \\
\hline northern pygmy-owl & & 1 & 1 & & & & \\
\hline common nighthawk & & & & & & 2 & 2 \\
\hline white-throated swift & & & 3 & & 4 & & \\
\hline black-chinned hummingbird & & & 6 & 2 & 2 & & 7 \\
\hline calliope hummingbird & & & & & & & 3 \\
\hline broad-tailed hummingbird & & 8 & 7 & 2 & 7 & 2 & 12 \\
\hline rufous hummingbird & & & & & 1 & & 40 \\
\hline acorn woodpecker & 1 & 2 & 11 & 1 & 8 & 3 & 7 \\
\hline red-naped sapsucker & & 2 & & & & & \\
\hline hairy woodpecker & 1 & & 5 & 3 & 1 & 2 & 2 \\
\hline northern flicker & 1 & 6 & 7 & 4 & 18 & 3 & 8 \\
\hline western wood-pewee & & & 7 & 4 & 7 & 2 & 9 \\
\hline gray flycatcher & & & & & 2 & & \\
\hline cordilleran flycatcher & & & 5 & 2 & 5 & 5 & 4 \\
\hline black phoebe & 1 & 1 & 3 & 1 & 5 & 1 & 3 \\
\hline Say's phoebe & 1 & 2 & & & 1 & & 3 \\
\hline dusky-capped flycatcher & & 1 & & & & & \\
\hline ash-throated flycatcher & & 4 & 4 & 2 & 9 & 7 & 10 \\
\hline Cassin's kingbird & & & 6 & & 7 & & 16 \\
\hline Bell's vireo & & 1 & & & & & \\
\hline plumbeous vireo & & 5 & 1 & 7 & 4 & 3 & 5 \\
\hline warbling vireo & & 7 & 14 & & 10 & 6 & 8 \\
\hline Steller's jay & & 8 & 9 & 2 & 11 & 6 & 7 \\
\hline western scrub-jay & 1 & 1 & 4 & 2 & 5 & 14 & 7 \\
\hline pinyon Jay & & 5 & & 27 & & 10 & 3 \\
\hline common raven & 1 & 10 & 7 & 4 & 5 & 6 & 5 \\
\hline purple martin & & 15 & 6 & 5 & 17 & 4 & 30 \\
\hline violet-green swallow & & 20 & 36 & 3 & 63 & 19 & 87 \\
\hline northern rough-winged swallow & 1 & & 5 & 1 & 2 & & \\
\hline cliff swallow & 1 & & 1 & & 39 & & 25 \\
\hline barn swallow & & & & 1 & & & \\
\hline mountain chickadee & & 2 & 1 & & 2 & & \\
\hline bridled titmouse & 1 & 2 & & 4 & 4 & & 1 \\
\hline bushtit & & 4 & 11 & 14 & 4 & 3 & 46 \\
\hline white-breasted nuthatch & & 5 & & & 3 & 1 & 7 \\
\hline pygmy nuthatch & & & & & 9 & 1 & 4 \\
\hline rock wren & & 1 & & & 3 & & 1 \\
\hline canyon wren & & 3 & 7 & 9 & 4 & 4 & 8 \\
\hline Bewick's wren & 1 & 1 & 1 & 1 & 2 & 1 & 1 \\
\hline
\end{tabular}




\begin{tabular}{|c|c|c|c|c|c|c|c|}
\hline \multirow[b]{2}{*}{ Species } & \multirow{2}{*}{$\frac{\text { April }}{15-30}$} & \multicolumn{2}{|c|}{ May } & \multicolumn{2}{|c|}{ June } & \multicolumn{2}{|c|}{ July } \\
\hline & & $1-15$ & $16-31$ & $1-15$ & $16-30$ & $1-15$ & $15-31$ \\
\hline house wren & 1 & 12 & 23 & 7 & 17 & 7 & 15 \\
\hline blue-gray gnatcatcher & & 4 & 4 & 1 & & 1 & 1 \\
\hline western bluebird & & 1 & 4 & & 2 & & 4 \\
\hline Townsend's solitaire & & & & 1 & & & \\
\hline hermit thrush & & 1 & & & & & \\
\hline American robin & 1 & 17 & 24 & 15 & 26 & 13 & 14 \\
\hline gray catbird & & & & & 1 & & \\
\hline northern mockingbird & & & & & & & 3 \\
\hline curve-billed thrasher & & & & & 1 & & \\
\hline olive warbler & & & & 1 & & & \\
\hline orange-crowned warbler & & 1 & 1 & & & & \\
\hline Virginia's warbler & & 6 & 12 & 2 & 9 & 2 & 5 \\
\hline yellow warbler & 1 & 2 & 2 & & 15 & 1 & 7 \\
\hline yellow-rumped warbler & 1 & 3 & & & & & \\
\hline black-throated gray warbler & & 5 & 3 & 1 & 5 & & 1 \\
\hline Townsend's warbler & & 2 & & & & & \\
\hline Grace's warbler & & 2 & & & 1 & & \\
\hline Macgillivray's warbler & & 2 & 4 & & & & \\
\hline common yellowthroat & & & 1 & 1 & 1 & & \\
\hline Wilson's warbler & 1 & 4 & 6 & & & & \\
\hline red-faced warbler & & 3 & 2 & & 3 & 2 & 1 \\
\hline painted redstart & & 6 & 9 & 3 & 10 & 6 & 11 \\
\hline yellow-breasted chat & & 7 & 6 & 3 & 16 & 5 & 12 \\
\hline hepatic tanager & & 6 & 3 & 2 & 7 & 4 & 6 \\
\hline western tanager & & 11 & 12 & 5 & 11 & 6 & 9 \\
\hline green-tailed towhee & & 5 & 2 & & & & \\
\hline spotted towhee & 1 & 16 & 28 & 13 & 34 & 12 & 35 \\
\hline canyon towhee & 1 & 2 & 1 & 1 & 7 & & 12 \\
\hline chipping sparrow & & 4 & & & & & 4 \\
\hline Brewer's sparrow & & 1 & & & & & \\
\hline lark sparrow & & & & & & 2 & 23 \\
\hline Lincoln's sparrow & & 5 & & & & & \\
\hline white-crowned sparrow & 2 & & 2 & & & & \\
\hline dark-eyed junco & & 11 & & & 1 & & \\
\hline black-headed grosbeak & & 15 & 29 & 4 & 14 & 5 & 7 \\
\hline blue grosbeak & & & 1 & 3 & 5 & 5 & 19 \\
\hline lazuli bunting & & & 1 & & & & 2 \\
\hline indigo bunting & & & & & 1 & & 1 \\
\hline yellow-headed blackbird & & & & & & 1 & \\
\hline Brewer's blackbird & & 5 & 6 & & 2 & & \\
\hline brown-headed cowbird & & 9 & 6 & 2 & 5 & 2 & 1 \\
\hline Bullock's oriole & & & 5 & & 1. & & 6 \\
\hline house finch & 1 & 2 & 1 & & 8 & 1 & 8 \\
\hline red crossbill & & & 1 & & & & \\
\hline lesser goldfinch & 1 & & 1 & & 16 & 1 & 25 \\
\hline
\end{tabular}


Appendix L. Additional bat-netting data, Gila Cliff Dwellings NM, 2001 and 2002. See Table 6.4 for additional analyses by site.

\begin{tabular}{|c|c|c|c|c|}
\hline Site & Date & Species & Sex & $\begin{array}{c}\text { Number of } \\
\text { individuals captured }\end{array}$ \\
\hline Cliff Dweller Canyon 1 & 09/13/2001 & no bats caught & & \\
\hline Cliff Dweller Canyon 2 & $05 / 29 / 2001$ & no bats caught & & \\
\hline Middle Fork of Gila River & $05 / 28 / 2003$ & no bats caught & & \\
\hline \multirow[t]{12}{*}{ West Fork Gila River 1} & $05 / 27 / 2001$ & big brown bat & $M$ & 1 \\
\hline & & hoary bat & $\mathrm{M}$ & 2 \\
\hline & & silver-haired bat & $M$ & 7 \\
\hline & $06 / 22 / 2002$ & California myotis & $\mathrm{F}$ & 1 \\
\hline & & Mexican freetail bat & $\mathrm{F}$ & 1 \\
\hline & & Mexican freetail bat & M & 7 \\
\hline & & Arizona myotis & $\mathrm{F}$ & 4 \\
\hline & & Arizona myotis & M & 2 \\
\hline & 08/29/2002 & big brown bat & M & 1 \\
\hline & & Arizona myotis & $\mathrm{F}$ & 1 \\
\hline & & Arizona myotis & M & 1 \\
\hline & & southwestern myotis & $\mathrm{F}$ & 1 \\
\hline West Fork Gila River 4 & $08 / 27 / 2002$ & Mexican freetail bat & M & 1 \\
\hline West Fork Gila River 5 & $08 / 28 / 2002$ & no bats caught & & \\
\hline \multirow[t]{17}{*}{ West Fork Gila River 6} & $05 / 25 / 2001$ & hoary bat & M & 1 \\
\hline & $05 / 26 / 2001$ & Mexican freetail bat & $F$ & 1 \\
\hline & & big brown bat & M & 1 \\
\hline & & hoary bat & M & 3 \\
\hline & & Arizona myotis & $\mathrm{F}$ & 1 \\
\hline & & silver-haired bat & $M$ & 9 \\
\hline & & southwestern myotis & $\mathrm{F}$ & 1 \\
\hline & 09/12/2001 & no bats caught & & \\
\hline & 06/20/2002 & Mexican freetail bat & $\mathrm{F}$ & 3 \\
\hline & & Mexican freetail bat & $\mathrm{M}$ & 3 \\
\hline & & big brown bat & $F$ & 1 \\
\hline & & big freetail bat & $\mathrm{F}$ & 1 \\
\hline & & hoary bat & $\mathrm{M}$ & 1 \\
\hline & $06 / 21 / 2002$ & Mexican freetail bat & M & 5 \\
\hline & & big brown bat & $\mathrm{M}$ & 2 \\
\hline & & hoary bat & $\mathrm{M}$ & 1 \\
\hline & & Arizona myotis & $\mathrm{M}$ & 1 \\
\hline
\end{tabular}


Appendix M. Number of individual small mammals trapped $(n)$ and relative abundance (RA) adjusted for trap nights at each group, site, and visit number, Gila Cliff Dwellings NM, 2001 and 2002. Data are summarized in Table 6.5. See Table 6.2 for information on trapping effort by site.

\begin{tabular}{|c|c|c|c|c|c|c|c|c|c|c|c|c|c|c|c|c|c|c|c|c|}
\hline \multirow[b]{5}{*}{ Species } & \multicolumn{20}{|c|}{ Group, Site name, Visit number } \\
\hline & \multicolumn{20}{|c|}{ West Fork $^{\mathrm{a}}$} \\
\hline & \multirow{2}{*}{\multicolumn{2}{|c|}{$\frac{A}{1}$}} & \multicolumn{12}{|c|}{ 年 } & \multirow{2}{*}{\multicolumn{2}{|c|}{$\frac{C}{1}$}} & \multicolumn{4}{|c|}{ GRB } \\
\hline & & & \multicolumn{2}{|c|}{1} & \multicolumn{2}{|c|}{2} & \multicolumn{2}{|c|}{3} & \multicolumn{2}{|c|}{4} & \multicolumn{2}{|c|}{5} & \multicolumn{2}{|c|}{6} & & & \multicolumn{2}{|c|}{1} & \multicolumn{2}{|c|}{2} \\
\hline & $n$ & $\mathrm{RA}$ & $n$ & $\mathrm{RA}$ & $n$ & $\mathrm{RA}$ & $n$ & $\mathrm{RA}$ & $n$ & $\mathrm{RA}$ & $n$ & $\mathrm{RA}$ & $n$ & RA & $n$ & $\mathrm{RA}$ & $n$ & $\mathrm{RA}$ & $n$ & $\mathrm{RA}$ \\
\hline $\begin{array}{l}\text { western harvest } \\
\text { mouse }\end{array}$ & 7 & 11.5 & 7 & 12.6 & 2 & 4.1 & 2 & 5.6 & 3 & 5.2 & 7 & 12.6 & 2 & 3.4 & 3 & 4.6 & 3 & 6.7 & 1 & 1.4 \\
\hline deer mouse & & & 1 & 1.8 & & & & & & & & & 1 & 1.7 & & & & & & \\
\hline brush mouse & 5 & 8.2 & 8 & 14.4 & 11 & 22.4 & 9 & 25.0 & 11 & 19.1 & 5 & 9.0 & 3 & 5.2 & 5 & 7.6 & 6 & 13.3 & 1 & 1.4 \\
\hline $\begin{array}{l}\text { western white- } \\
\text { throated woodrat }\end{array}$ & & & 1 & 1.8 & 3 & 6.1 & 3 & 8.3 & 4 & 7.0 & & & 1 & 1.7 & & & & & & \\
\hline Mexican woodrat & & & & & & & & & & & & & 1 & 1.7 & & & & & & \\
\hline Mexican vole & & & & & & & & & 2 & 3.5 & 1 & 1.8 & & & & & & & & \\
\hline
\end{tabular}

a No animals were trapped at "FW" site.

\begin{tabular}{|c|c|c|c|c|c|c|c|c|c|c|c|c|c|c|c|c|}
\hline \multirow[b]{5}{*}{ Species } & \multicolumn{16}{|c|}{ Group, Site name, Visit number } \\
\hline & \multicolumn{4}{|c|}{$\begin{array}{c}\text { Random- TJ Ruins } \\
\text { Unit }\end{array}$} & \multirow{2}{*}{\multicolumn{8}{|c|}{$\frac{\text { Random- West unit }{ }^{\text {a }}}{\text { L3 }}$}} & \\
\hline & \multirow{2}{*}{\multicolumn{2}{|c|}{$\begin{array}{c}\mathrm{G} 1 \\
1\end{array}$}} & \multirow{2}{*}{\multicolumn{2}{|c|}{$\frac{\mathrm{G} 2}{1}$}} & & & & & & & & & & & \multirow{2}{*}{\multicolumn{2}{|c|}{2}} \\
\hline & & & & & & 1 & & 2 & \multicolumn{2}{|c|}{1} & \multicolumn{2}{|c|}{2} & \multicolumn{2}{|c|}{1} & & \\
\hline & $n$ & $\mathrm{RA}$ & $n$ & $\mathrm{RA}$ & $n$ & $\mathrm{RA}$ & $n$ & RA & $n$ & $\mathrm{RA}$ & $n$ & $\mathrm{RA}$ & $n$ & RA & $n$ & $\mathrm{RA}$ \\
\hline cliff chipmunk & & & & & & & & & 1 & 1.0 & & & & & & \\
\hline western harvest mouse & & & & & 1 & 2.1 & & & & & & & & & & \\
\hline brush mouse & 1 & 1.4 & 1 & 1.4 & 1 & 2.1 & & & 2 & 2.1 & 1 & 1.4 & & & & \\
\hline western white-throated woodrat & & & 2 & 2.8 & & & & & & & & & & & 1 & 2.0 \\
\hline Mexican woodrat & & & 1 & 1.4 & & & & & & & & & & & & \\
\hline
\end{tabular}

a No animals were trapped at " $\mathrm{L6}$ " site.

\begin{tabular}{|c|c|c|c|c|c|c|c|c|c|c|c|c|c|c|}
\hline \multirow[b]{5}{*}{ Species } & \multicolumn{14}{|c|}{ Group, Site name, Visit number } \\
\hline & \multicolumn{8}{|c|}{ Mesa } & \multicolumn{6}{|c|}{ Cliff Dweller Canyon } \\
\hline & \multirow{2}{*}{\multicolumn{2}{|c|}{$\frac{\text { Mesa D }}{1}$}} & \multirow{2}{*}{\multicolumn{2}{|c|}{$\frac{\text { Mesa E }}{1}$}} & \multirow{2}{*}{\multicolumn{2}{|c|}{$\begin{array}{c}\text { Mesa F } \\
1\end{array}$}} & \multirow{2}{*}{\multicolumn{2}{|c|}{$\frac{\text { Mesa G }}{1}$}} & \multicolumn{4}{|c|}{ CDC 1} & \multirow{2}{*}{\multicolumn{2}{|c|}{$\frac{\mathrm{CDC} 2}{1}$}} \\
\hline & & & & & & & & & & & & 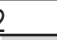 & & \\
\hline & $n$ & RA & $n$ & RA & $n$ & RA & $n$ & RA & $n$ & RA & $n$ & RA & $n$ & RA \\
\hline cliff chipmunk & 1 & 1.7 & & & & & 1 & 1.6 & & & & & & \\
\hline deer mouse & 1 & 1.7 & & & & & 1 & 1.6 & & & & & & \\
\hline brush mouse & 3 & 5.1 & & & 1 & 1.4 & 4 & 6.3 & 2 & 2.1 & 4 & 6.1 & 2 & 23.5 \\
\hline piñon mouse & & & & & 2 & 2.8 & 1 & 1.6 & & & & & & \\
\hline western white-throated woodrat & 3 & 5.1 & 2 & 2.7 & 1 & 1.4 & 5 & 7.8 & & & & & 1 & 11.8 \\
\hline
\end{tabular}


